\title{
Studying of Research Related to COVID-19 Vaccine in Iran and the World: A Thematic Analysis and Scientific Collaborations \\ Somayeh Jafari Baghiabadi ${ }^{1}$, Razieh Farshid²*iD
}

1. Department of Information Science, Faculty of Management, University of Tehran, Tehran, Iran

2. Department of Information Science, Faculty of Psychology and Educational Sciences, Kharazmi University, Tehran, Iran

\section{ABSTRACT}

Background and Aim: The purpose of the present study is thematic analysis and scientific collaborations of research related to COVID-19 vaccine in Iran and the world based on scientific products indexed in Web of Science (WOS).

Materials and Methods: The present study is a descriptive-analytical study with a scientometric approach and using the methods of content analysis and techniques of co-word analysis, hierarchical clustering, Strategic graph and social network analysis. The research population is scientific products related to COVID-19 vaccine in the world and in Iran. Data analysis was performed by HistCite, Bibexecl, Gephi and SPSS software; and the data mapping is done by VOS viewer.

Results: Between 2019 and 2021, 6005 related studies were retrieved. Unites states is followed by India and China, and the United Kingdom has the most Links. Iran's rank is 10th with 196 studies. Hierarchical clustering in global research led to the formation of 3 clusters (vaccine development strategy, medical prevention and immunotherapy) and in Iranian research led to the formation of 4 clusters (immunotherapy, diagnosis and treatment cycle, medical prevention and immunology). From scientific collaborations at the country level in world and Iranian studies, 5 clusters were formed, at the level of institutions, 17 and 10 clusters, respectively, and at the level of researchers, 10 and 8 clusters, respectively.

Conclusion: Analysis and comparison of world and Iranian studies leads to a better understanding of the prevailing currents, Gaps and discourse in order to increase the quantity and quality of studies, followed by controlling and the eradication of COVID-19 in the shortest possible time.

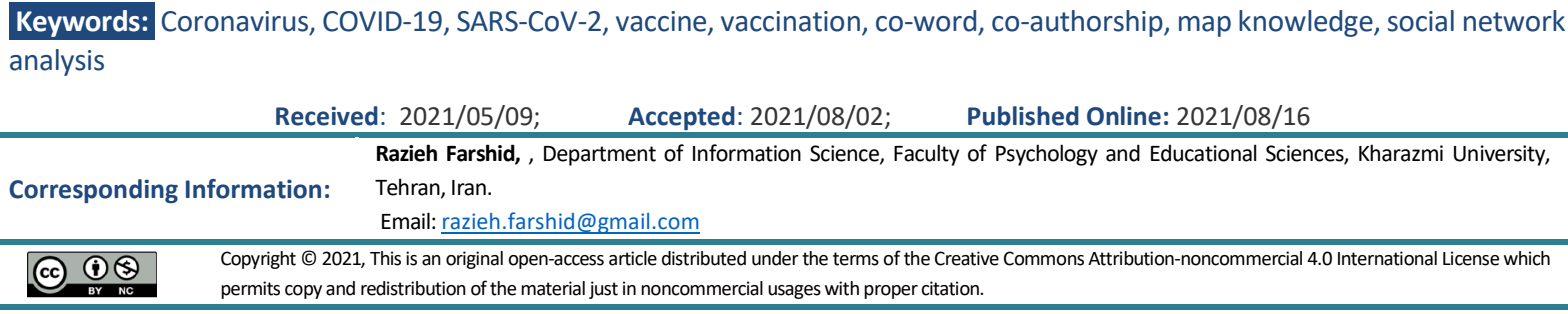

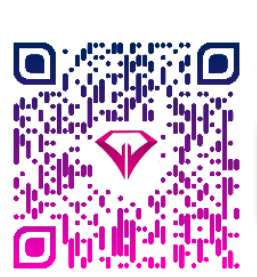

Use your device to scan and read the article online

Download citation: BibTeX | RIS | EndNote | Medlars | ProCite | Reference Manager | RefWorks

Send citation to: $\otimes \underline{\text { Mendeley }} 2$ zotero $\underline{H}$ RefWorks

\section{Introduction}

New coronavirus known as severe acute respiratory syndrome coronavirus 2 (SARS-CoV-2) was first identified in Wuhan, China, and was confirmed by the World Health Organization (1) followed by rapid spread throughout the world. The disease is highly contagious and unknown in terms of origin, symptoms, routes of transmission and spread, prevention, diagnosis, treatment, effective medications, mortality rate, and vacci- nation $(2,3)$. Therefore, researchers in diverse scientific fields designed and conducted related studies in the world (4) as the number of valid investigations grew considerably in citation databases in a short time (5).

Coronavirus is one of the viruses first transmitted among animals and then to humans. It was named due to crown-like spikes (protein spikes) on the surface (6, 7). The signs of this disease, including fever, cough, 
fatigue, sputum, headache, hemorrhage, diarrhea, dyspnea, and lymphopenia present in 2-5 days and are similar to Influenza and SARS (8). However, being a contagious and severe respiratory failure in some people leading to mortality is among the unique signs of this disease $(9,10)$.

Design and development of an efficient vaccine was the priority of governments, scientific centers, and researchers since the beginning of the pandemic because of the increasing number of affected individuals and mortality, the lack of influential treatments, and the presence of asymptomatic carriers in society $(11,12)$. In other words, vaccination along with hygienic protocols are considered the most reliable, most cost-effective, and most influential preventive measures against fatal infectious diseases. A vaccine is a biological preparation that provides active acquired immunity against a special disease (12). Diverse types of vaccines entail live-attenuated, inactivated, subunit, recombinant, polysaccharide, conjugate, and toxoid vaccines (13).

Complete information concerning antigenic properties, adjuvant, as well as vaccine production and delivery system, should be available for designing a vaccine (14). The availability of SARS-CoV-2 genomic and structural data allowed the production of various vaccines for this virus (15). Therefore, efforts for vaccine development started at the beginning of the pandemic and are still ongoing as over 100 vaccines are currently being tested in terms of efficacy in animals. Moreover, many vaccines are under clinical trial in humans and some have reached the final test step. About 15 vaccines have been approved and are being inoculated as governmental vaccination programs (16).

According to the latest international records, 11 SARS-CoV-2 vaccines are currently in phase III clinical trial. Several vaccines, namely Russian Sputnik, American Pfizer and Moderna, English Oxford, and Chinese Sinovac received approval for injection. In this regard, numerous studies have been published since the beginning of the pandemic on different phases, including laboratory evaluations, design and production, animal tests, clinical trials, mass production, public vaccination, and other issues. Iranian researchers also played role in these investigations.

Currently, Iran has the eleventh rank among 16 SARS-CoV-2 vaccine producers in the world regarding the number of vaccines despite international sanctions. According to the Ministry of Health and Medical Education, 12 teams are working on the production of SARS-CoV-2 vaccine, including the Execution of Imam khomeini's Faraman and Barekat Institute, Pasteur Institute of Iran, Razi Vaccine and Serum Research Institute, some universities of medical sciences, Mini- stry of Defense and Armed Forces Logistics, and several science-based companies and institutes. Eight projects have been reported to be more active now (17).

In such conditions, researchers in diverse domains, such as biochemistry, molecular biology, immunology, virology, experimental medicine, medical research, pharmacology, and infectious diseases cooperate for investigation and vaccine production against SARSCoV-2. Consequently, interdisciplinary domains, research cooperation, and novel research fields will emerge in national and international research and technology domains that might lead to changes in the future.

Interdisciplinary fields resulting from emerging scientific collaboration present the most relevant and most effective researchers in the field of SARS-CoV-2 vaccine research (18). On the other hand, researchers develop the scientific future of their specialty. The regular identification and assessment of scientific outcomes are of high priority for obtaining knowledge concerning the existing conditions $(19,20)$. In this regard, drawing the map (structure) of scientific domains has attracted attention as one of the most important aspects of Scientometrics studies in recent decades (21).

Scientometrics is aimed to evaluate science structure in scientific domains and benefits from variable techniques, such as co-citation, co-word, and coauthorship. The main concepts of a specific field could be recognized using co-citation and a suitable understanding is provided, in addition to the evaluation of changes during the time (22). In the co-word method, utilizing common concepts in title, abstract, keywords, and text in scientific publications demonstrates the closeness of the concepts and subjects of these studies. As a result, the structure, concepts, and components of a scientific field could be determined (23).

The considerable difference between co-word and co-citation analyses from $\mathrm{He}$ viewpoint is that cocitation requires citing references (citing papers, citing authors) and cited reference (cited author, cited document) (24). On the other hand, research-academic centers and researchers share their ideas in scientific collaboration and promote scientific publications qualitatively and quantitatively (25). Therefore, evaluating the co-authorship of scientific publications in different countries considers the aspects and extend of scientific collaboration, countries, organizations, and researchers that are remarkable in terms of scientific outcome (26). Here, we review the studies performed with the mentioned approaches in the field of the SARS-CoV-2 vaccine.

A Scientometrics investigation by Surulinathi et al. in 2020 evaluated the research outcomes in SARS-CoV-2 and coronavirus vaccine domains. The latter study analyzed 7181 investigations in the field of corona- 
virus vaccine indexed in the Web of Science during 1971-2020. A total of 4402 studies in 2020 showed growth in investigations. Documents published in Vaccine journal had the highest number of 203 papers followed by Virology and Nature with 104 and 96 publications, respectively. The most productive countries were the United States of America, China, India, and England with 2178 ( $\mathrm{H}$-index: 114), 1068 ( $\mathrm{H}$ index: 75), 678 (H-index: 26), and 614 (H-index: 53) papers, respectively (27).

Another study by Surulinathi et al. in 2021 aimed to draw the science map of highly cited researches in the SARS-CoV-2 vaccine domain. A total of 433 investigations on the COVID-19 vaccine that had 52567 citations were assessed. The mean number of citations for each study was 121.4. Studies in this field peaked in 2020 with 97 research that received at least 500 citations and the highest number of citations (14623) in 2021. The USA had the largest share (229 studies) and received 29027 citations followed by China with 13798 citations for 114 research, England with 4314 citations for 35 studies, Germany with 3404 citations for 33 investigations, and Netherland with 28 citations for 28 publications.

The mentioned study indicated that India recorded 705 citations for 9 investigations. The National Institute of Allergy and Infectious Diseases from the USA had 39 studies and 6076 citations, followed by University N Carolina with 31 studies and 4118 citations, the University of Hong Kong with 23 research and 3546 citations, New York Blood Centre with 21 studies and 2931 citations. Virology journal with 5724 citations for 53 studies, Science journal with 4163 citations for 13 research, the National Academy of Sciences of the United States of America with 3113 citations for 20 investigations, Nature journal with 2250 citations for 13 studies, and Lancet with 1528 citations for 8 papers had the best records. Among these studies, 18 publications had one author and 2906 investigations had several authors (28).

Ahmad et al. in a Scientometrics study evaluated research trends in SARS-CoV-2 vaccine studies. The latter study conducted on 12 January 2020 in WOS analyzed 916 investigations performed by 4392 authors and published in 376 journals. Their findings demonstrated that most retrieved studies were articles (372 research, 40.6\%). The authors with the highest number of studies were Dhama K and Hotez PJ (10 research, 1.1\%). The most active institute was Oxford University (24 research, 2.6\%) and the most important journal was Human Vaccine and Immunotherapeutics (43 research, 4.7\%). The most common keywords entailed "COVID-19" (597 studies, 65.2\%) and "Vaccine" (521 studies, 56.9\%). The USA was the most productive country (352 studies, 38.4\%) (29).
In the study completed by Ay et al., on 20 January 2021, total of 2765 research with 24202 citations existed on the Web of Science. Immunology, internal medicine, and experimental medicine research were had the highest ranks. Active universities in this field encompassed the universities of Harvard, California, and London. Biomolecular Structure Dynamics publicshed the highest number of studies. The USA was the most active country among the contributing countries followed by China and India (30).

Therefore, considering the high prevalence of SARSCoV-2, the increased number of patients and mortality, and the importance of using vaccines for managing this crisis, followed by increased research related to the SARS-COV-2 vaccine from various perspectives and based on background review that have only provided a kind of report on studies in this field, and considering over the past few decades, the study of scientific maps and collaboration as one of the most important aspects of measurement studies of science, has gained great importance in various fields (31), the present study aimed to identify and analyze the main and newly emerged research subjects, in addition to the international and national scientific collaboration in SARS-CoV-2 vaccine investigations based on coword, co-authorship, and indices of Web of Science. Recognizing the science structure in this field allows government, the Ministry of Health, scientific centers, researchers, and interested people to conduct and guide their studies toward applicable subjects and higher knowledge. In other words, the present study aimed to analyze and compare the concepts and words of studies indexed in the WOS database and the scientific collaboration of researchers in investigations on SARS-CoV-2 in the world ad Iran. In this regard, we answer the following questions:

1. How is the condition of studies on the SARS-CoV2 vaccine in the world and Iran in terms of study design, language, countries, institutes, cooperating researchers, research fields, and journals?

2. What are the clusters and subjects of researches on the SARS-CoV-2 vaccine in the world and Iran based on co-word analysis and hierarchical clustering? What is the position of obtained clusters regarding maturity and development in the strategic chart?

3. How are the networks of a scientific corporation in studies on SARS-CoV-2 vaccine in the world and Iran?

4. Who are the best researchers of Iran and the world in studies on the SARS-CoV-2 vaccine based on the central indices of social networking?.

\section{Materials and Methods}

This descriptive-analytical research was performed with the Scientometrics approach and content analysis method along with co-word analysis, 
hierarchical clustering, strategic chart, co-authorship, and social network analysis. Co-word analysis utilized in the current study was one of the content analysis methods. In network analysis, centrality indices that show the location of a node relative to other nodes in scientific maps are used. The statistical population of the present study included all investigations on the COVID-19 vaccine in WOS in categories related to medicine and health domains during 019-2021.

For the accurate recognition and retrieval of related researches, diverse combinations and names of COVID-19, as well as the words and terms related to the vaccine were identified using a thesaurus and medical subject headings (MeSH). Next, applying Boolean operators, truncation, and the following multistage search approach, the studies in the considered field were retrieved on 16 April 2021, including 6005 studies in text format in the world and 196 studies in text format in Iran:

((TS="COVID-19") OR (TS="coronavirus disease 2019") OR (TS="novel coronavirus") OR (TS="2019 ncov") OR (TS="coronavirus 2019") OR (TS="new coronavirus") OR (TS="Sars-Cov 2") OR (TS="nCoV19")) AND (TS=Vaccin*)

It should be noted that Clarivate Analytics has determined the maximum download records as 500 . Therefore, data extraction was performed in 14 steps. Following the retrieval of related records and data integration, data were analyzed by the Histcite, Bibexcel, Gephi, UCINET, and SPSS software according to the aims and questions of the research. The maps were drawn utilizing the VOSviewer software version 1.6.10. The subjective maps and analysis were carried out following the control and integration of keywords by thesaurus generation in the software as similar and identical keywords, and single and plural forms were merged and non-specialized keywords were removed.

Hierarchical clustering is applied for co-word analysis, which can determine the clusters related to each keyword and indicate the relationships between them. As a result, hierarchical clustering was performed using the SPSS software. In the hierarchical clustering method, similar to a tree, each small branch is a component of a larger branch and finally, all these are connected to the tree trunk hierarchically. In summary, the following steps should be passed:

1. Each item should be regarded as a cluster.

2. Among all possible cluster pairs, the two clusters with lower ESS are selected.
3. The two selected clusters are combined.

4. Steps 2 and 3 are repeated until all items are in one cluster or the number of clusters reaches the considered number.

In order to execute and finalize the co-occurring analysis, first, some necessary items, including cooccurring matrix are prepared. Afterwards, the cooccurring matrix is converted to a relationship matrix. To prepare the matrix, keywords with the frequency of 2 and 26 were selected for studies from Iran and other countries, respectively. Finally, rectangular matrices of $69 \times 69$ and $70 \times 70$ were made for investigations in Iran and other countries, respectively. The diagonal cells of matrices were considered zero and these matrices were converted to relationship matrices. The clustering of concepts was completed by the SPSS software version 26 .

In the next step, the strategic chart of subjective clusters was depicted. To this aim, the centrality and density of clusters were obtained by the UCINET software after forming separated matrices for the keywords of each cluster retrieved by a hierarchical chart. A strategic chart is a description of internal relations and correlations between distinct clusters. In this chart, the horizontal axis is commonly utilized to present centrality (the relationship between clusters) and the vertical axis is used to give density (the internal relations of each cluster).

\section{Results}

A total of 6005 studies published in the considered field during 2019-2021 were retrieved by searching the WOS and using the HistCite software. These papers had 29473 authors affiliated to 7988 universities and scientific institutes from 147 countries. Table 1 represents different factors of these studies, including the design, language, countries, involved institutes and researchers, and research domains. Each related study had a mean citation of 10.05 . The $\mathrm{H}$-index of this field was found as 109 in the WOS. 
Table 1. Status of Studies on COVID-19 vaccine in the world

\begin{tabular}{|c|c|c|c|c|c|}
\hline & $\begin{array}{c}\text { First place } \\
\text { (number, percent) }\end{array}$ & $\begin{array}{c}\text { Second place } \\
\text { (number, percent) }\end{array}$ & $\begin{array}{c}\text { Third place (number, } \\
\text { percent) }\end{array}$ & $\begin{array}{l}\text { Fourth place (number, } \\
\text { percent) }\end{array}$ & $\begin{array}{l}\text { Fifth place } \\
\text { (number, } \\
\text { percent) }\end{array}$ \\
\hline Doc. Type & $\begin{array}{c}\text { Article } \\
(3001,50)\end{array}$ & $\begin{array}{c}\text { Review } \\
(1578,3.26)\end{array}$ & $\begin{array}{l}\text { Editorial Material } \\
\qquad(721,12)\end{array}$ & $\begin{array}{l}\text { News Item } \\
(215,6.3)\end{array}$ & $\begin{array}{l}\text { Letter } \\
(208,5.3)\end{array}$ \\
\hline Language & English $(5837,97.2)$ & German $(51,0.8)$ & Spanish $(40,0.7)$ & French $(18,0.3)$ & Turkish $(11,0.2)$ \\
\hline Country & $\begin{array}{l}\text { United States } \\
(1584,9.30)\end{array}$ & India $(730,12.2)$ & China $(663,11)$ & England $(591,9.8)$ & Italy $(396,6.6)$ \\
\hline Researcher & $\begin{array}{c}\text { Dhama K, Mahase E } \\
(36,0.6)\end{array}$ & $\begin{array}{l}\text { Baric RS } \\
(25,0.4)\end{array}$ & $\begin{array}{l}\text { Kumar A } \\
(24,0.4)\end{array}$ & $\begin{array}{l}\text { Tiwari R } \\
(22,0.4)\end{array}$ & $\begin{array}{r}\text { Kumar S, } \\
(21,0.3)\end{array}$ \\
\hline Institute & $\begin{array}{l}\text { Harvard Med Sch } \\
\qquad(104,1.7)\end{array}$ & $\begin{array}{l}\text { Univ Oxford (103, } \\
1.7)\end{array}$ & $\begin{array}{l}\text { Univ Washington } \\
\qquad(85,1.4)\end{array}$ & $\begin{array}{c}\text { Chinese Acad Sci } \\
(66,1.1)\end{array}$ & $\begin{array}{c}\text { London Sch Hyg \& } \\
\text { Trop Med } \\
(64,1.1)\end{array}$ \\
\hline Funding Sponsor & $\begin{array}{c}\text { UNITED STATES } \\
\text { DEPARTMENT OF } \\
\text { HEALTH HUMAN } \\
\text { SERVICES } \\
(506,8.373)\end{array}$ & $\begin{array}{c}\text { NATIONAL } \\
\text { INSTITUTES OF } \\
\text { HEALTH NIH USA } \\
(492,8.142)\end{array}$ & $\begin{array}{l}\text { NATIONAL NATURAL } \\
\text { SCIENCE FOUNDATION } \\
\text { OF CHINA NSFC } \\
(210,3.475)\end{array}$ & $\begin{array}{l}\text { EUROPEAN COMMISSION } \\
(156,2.581)\end{array}$ & $\begin{array}{c}\text { NIH NATIONAL } \\
\text { INSTITUTE OF } \\
\text { ALLERGY } \\
\text { INFECTIOUS } \\
\text { DISEASES NIAID } \\
(140,2.317)\end{array}$ \\
\hline Journal & $\begin{array}{l}\text { BMJ-BRITISH } \\
\text { MEDICAL } \\
\text { JOURNAL } \\
(151,2.5)\end{array}$ & $\begin{array}{l}\text { VACCINES } \\
(133,2.2)\end{array}$ & $\begin{array}{l}\text { NATURE } \\
(102,7.1)\end{array}$ & $\begin{array}{l}\text { VACCINE } \\
(96,6.1)\end{array}$ & $\begin{array}{l}\text { FRONTIERS IN } \\
\text { IMMUNOLOGY } \\
(95,1.6)\end{array}$ \\
\hline Research Area & $\begin{array}{c}\text { GENERAL } \\
\text { INTERNAL } \\
\text { MEDICINE } \\
(874,14 / 463)\end{array}$ & $\begin{array}{l}\text { IMMUNOLOGY } \\
(830,13 / 735)\end{array}$ & $\begin{array}{l}\text { PHARMACOLOGY } \\
\text { PHARMACY (599, } \\
9.912)\end{array}$ & $\begin{array}{c}\text { RESEARCH EXPERIMENTAL } \\
\text { MEDICINE } \\
(577,9.548)\end{array}$ & $\begin{array}{c}\text { BIOCHEMISTRY } \\
\text { MOLECULAR } \\
\text { BIOLOGY, } \\
\text { SCIENCE } \\
\text { TECHNOLOGY } \\
\text { OTHER TOPICS } \\
(519,5.588)\end{array}$ \\
\hline
\end{tabular}

The considerable point is the $10^{\text {th }}$ rank of Iran among contributing countries with 196 studies. After limiting the retrieved results to Iran, 196 related investigations conducted during 2019-2021 that had 1583 authors affiliated to 635 universities and scientific institutes with the cooperation of 76 countries were retrieved from the mentioned databases. Table 2 summarizes the design, language, countries, involved institutes and researchers, research domains, and journals of studies in this field in Iran. Any related publication received 6.87 citations on average. Moreover, the $\mathrm{H}$-index of this field in Iran was 16 in the WOS.

Table 2. Status of Studies on COVID-19 vaccine in Iran

\begin{tabular}{|c|c|c|c|c|c|}
\hline & $\begin{array}{c}\text { First place (number, } \\
\text { percent) }\end{array}$ & $\begin{array}{c}\text { Second place } \\
\text { (number, percent) }\end{array}$ & $\begin{array}{c}\text { Third place (number, } \\
\text { percent) }\end{array}$ & $\begin{array}{c}\text { Fourth place } \\
\text { (number, percent) }\end{array}$ & $\begin{array}{c}\text { Fifth place (number, } \\
\text { percent) }\end{array}$ \\
\hline Doc. Type & Review $(114,58.2)$ & $\begin{array}{c}\text { Article } \\
(72,36.7)\end{array}$ & $\begin{array}{c}\text { Editorial Material } \\
\qquad(7,3.6)\end{array}$ & $\begin{array}{l}\text { Letter } \\
(3,1.5)\end{array}$ & - \\
\hline Researcher & $\begin{array}{c}\text { Rezaei N } \\
(8,1.4)\end{array}$ & $\begin{array}{c}\text { Abadi ATB } \\
(4,2)\end{array}$ & \multicolumn{3}{|c|}{$\begin{array}{l}\text { Akbari A, Hemmat N, Iravani S, Khodavirdipour A, } \\
\text { Lotfi M, Negahdaripour M, Nosrati H, } \\
\text { Pormohammad A, Rahimi F, Ranjbar R, } \\
\text { Sadeghi S, Sahebkar A, Soltani S, Soufi GJ, Zandi M } \\
\text { (3. 1.5) }\end{array}$} \\
\hline Institute & $\begin{array}{l}\text { Shahid Beheshti } \\
\text { University of } \\
\text { Medical Sciences, } \\
\text { Tehran University of } \\
\text { Medical Sciences } \\
(41,20.9)\end{array}$ & $\begin{array}{c}\text { Tabriz University of } \\
\text { Medical Sciences } \\
(20,10.2)\end{array}$ & $\begin{array}{c}\text { Shiraz university of } \\
\text { medical sciences } \\
(19,9.7)\end{array}$ & $\begin{array}{l}\text { Iran University of } \\
\text { Medical Sciences, } \\
\text { Mashhad University } \\
\text { of Medical Sciences } \\
(18,9.2)\end{array}$ & $\begin{array}{c}\text { Trabiat Modares } \\
\text { University } \\
(15,7.7)\end{array}$ \\
\hline Funding Sponsor & $\begin{array}{l}\text { TEHRAN } \\
\text { UNIVERSITY OF } \\
\text { MEDICAL SCIENCES } \\
(4,2.041)\end{array}$ & $\begin{array}{l}\text { CGIAR, NATIONAL } \\
\text { INSTITUTE OF } \\
\text { GENETIC } \\
\text { ENGINEERING AND } \\
\text { BIOTECHNOLOGY }\end{array}$ & \multicolumn{3}{|c|}{$\begin{array}{l}\text { HAMADAN UNIVERSITY OF MEDICAL SCIENCES HAMADAN IRAN, } \\
\text { NATIONAL INSTITUTE FOR HEALTH RESEARCH NIHR, NATIONAL } \\
\text { INSTITUTES OF HEALTH NIH USA, } \\
\text { RESEARCH COUNCIL OF SHIRAZ UNIVERSITY OF MEDICAL SCIENCES } \\
\text { SHIRAZ IRAN, }\end{array}$} \\
\hline
\end{tabular}




\begin{tabular}{|c|c|c|c|c|c|}
\hline & $\begin{array}{c}\text { First place (number, } \\
\text { percent) }\end{array}$ & $\begin{array}{c}\text { Second place } \\
\text { (number, percent) }\end{array}$ & $\begin{array}{c}\text { Third place (number, } \\
\text { percent) }\end{array}$ & $\begin{array}{c}\text { Fourth place } \\
\text { (number, percent) }\end{array}$ & $\begin{array}{c}\text { Fifth place (number, } \\
\text { percent) }\end{array}$ \\
\hline & & $\begin{array}{l}\text { NIGEB OF THE } \\
\text { ISLAMIC REPUBLIC OF } \\
\text { IRAN, PASTEUR } \\
\text { INSTITUTE OF IRAN, } \\
\text { SHIRAZ UNIVERSITY } \\
\text { OF MEDICAL } \\
\text { SCIENCES } \\
(3,1.531)\end{array}$ & \multicolumn{3}{|c|}{$\begin{array}{l}\text { TURKIYE BILIMSEL VE TEKNOLOJIK ARASTIRMA KURUMU TUBITAK, } \\
\text { IRAN S NATIONAL ELITES FOUNDATION } \\
(2,1.07)\end{array}$} \\
\hline Journal & $\begin{array}{l}\text { JOURNAL OF } \\
\text { BIOMOLECULAR } \\
\text { STRUCTURE \& } \\
\text { DYNAMICS } \\
(8,1.4)\end{array}$ & \multicolumn{2}{|c|}{$\begin{array}{c}\text { ARCHIVES OF MEDICAL RESEARCH, } \\
\text { BIOLOGICAL PROCEDURES ONLINE, } \\
\text { INTERNATIONAL IMMUNOPHARMACOLOGY, } \\
\text { BIOMEDICINE \& PHARMACOTHERAPY } \\
\text { PLOS ONE, } \\
\text { REVIEWS IN MEDICAL VIROLOGY } \\
(4,2)\end{array}$} & \multicolumn{2}{|c|}{$\begin{array}{c}\text { ARCHIVES OF BONE AND JOINT SURGERY-ABJS, } \\
\text { EXPERT REVIEW OF ANTI-INFECTIVE THERAPY, } \\
\text { JOURNAL OF CELLULAR PHYSIOLOGY, } \\
\text { VACCINE, } \\
\text { EUROPEAN JOURNAL OF PHARMACOLOGY, } \\
\text { ARCHIVES OF CLINICAL INFECTIOUS DISEASES } \\
(3,1.5)\end{array}$} \\
\hline Research Area & $\begin{array}{l}\text { PHARMACOLOGY } \\
\text { PHARMACY } \\
(39,19.898)\end{array}$ & $\begin{array}{l}\text { BIOCHEMISTRY } \\
\text { MOLECULAR } \\
\text { BIOLOGY } \\
(29,14.735)\end{array}$ & $\begin{array}{c}\text { RESEARCH } \\
\text { EXPERIMENTAL } \\
\text { MEDICINE } \\
(22,11.224)\end{array}$ & $\begin{array}{c}\text { IMMUNOLOGY } \\
(19,9.694)\end{array}$ & $\begin{array}{l}\text { INFECTIOUS } \\
\text { DISEASES } \\
(14,7.143)\end{array}$ \\
\hline
\end{tabular}

In the next step of the study, all investigations extracted from WOS were entered in VOSviewer software for drawing and analyzing the clusters and subjects related to the COVID-19 vaccine separated based on Iran and other countries. Here, you can find the science map of world and Iran studies, as well as their keywords based on central indices.

\section{World studies}

Seven clusters of words and concepts were identified following co-word analysis. The study with the most citation was "Cryo-EM structure of the 2019-nCoV spike in the prefusion conformation" by Goldsmith JA, Corbett KS, Wang NS, Wrapp D, Hsieh CL, Abiona O, Graham BS, and McLellan JS published in Science journal in 2020. Figure 1 demonstrates the map of the concepts of studies on the COVID-19 vaccine throughout the world. The larger circles show the higher application of those concepts for describing the studies and their colors indicate the cluster of concepts. In addition, the closeness of keywords in this map reveals how interrelated the concepts are.

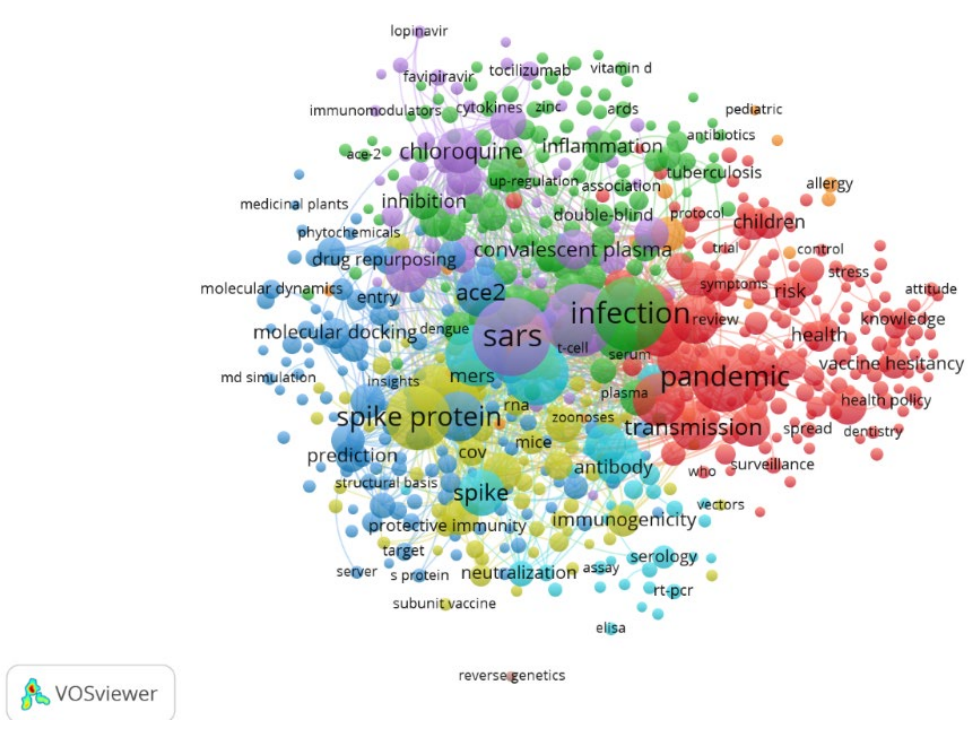

Figure 1. Concepts and subject clusters of studies on COVID-19 vaccine in the world

Hierarchical clustering was performed and dendrograms (hierarchical clustering) of subjects were drawn using the SPSS software and co-occurrence matrices. The hierarchical clustering of investigations on the COVID-19 vaccine is depicted in Figure 2. The clusters have been divided into several parts for higher resolution. In this figure, the height of each cluster shows the points at which the two intended clusters are combined. Moreover, the red vertical lines are the indicator lines of interpretation depicted based on the ideas of specialists (26). 


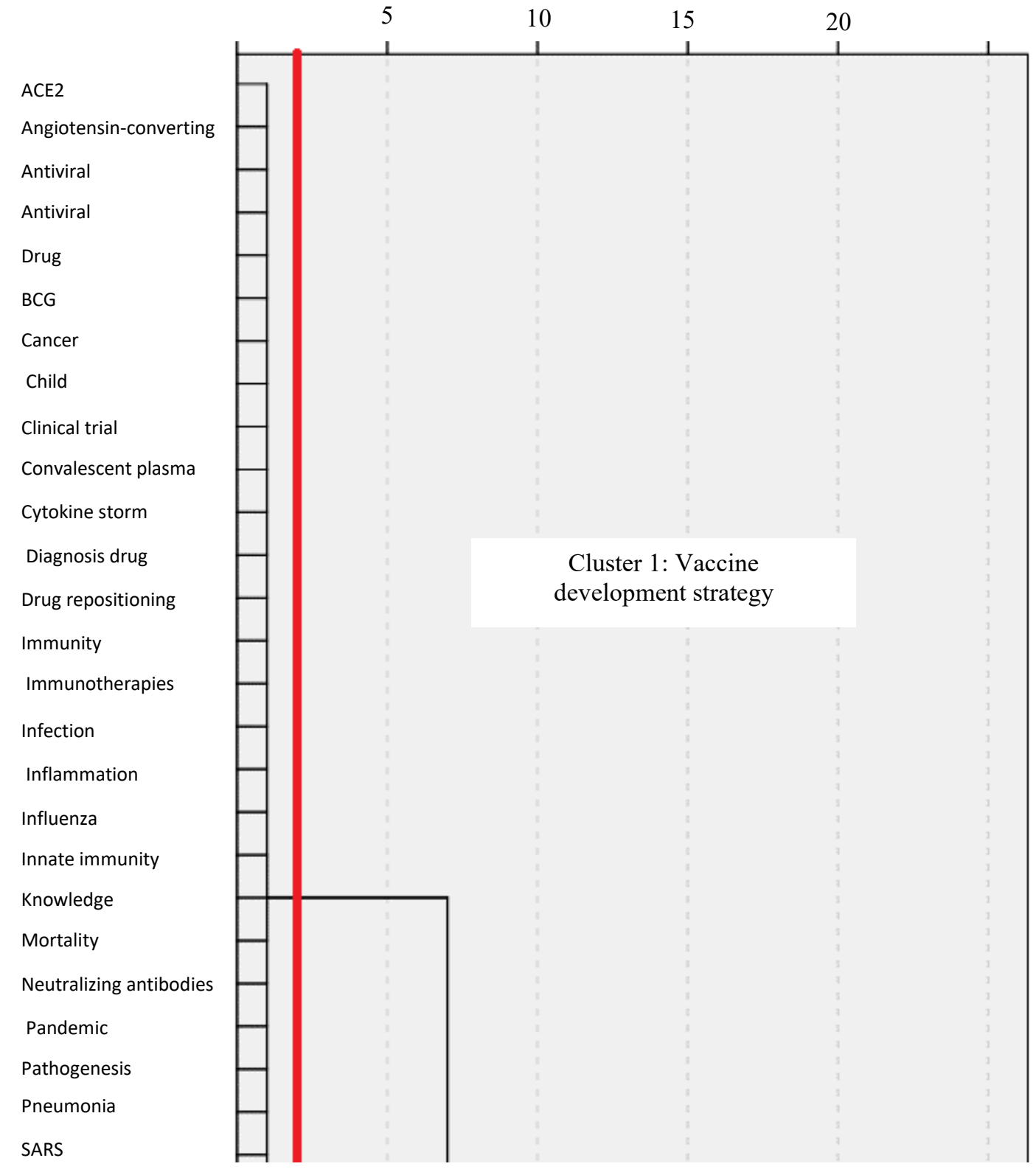


5

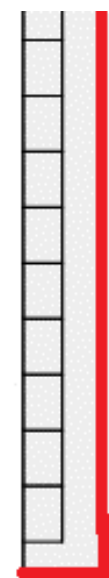

1

15

20

Serology

Social distance

Spike (S) protein

Spike glycoprotein

T cell

Transmission

Treatment

Vaccination

Vaccine

Vaccine development Virus

Adjuvant

Corona

Coronavirus infection

COVID-19 vaccine

Epidemic

Epitope

Hydroxychloroquine

Immunization

Immunoinformatic

Immunology

Infectious disease

Molecular docking

Mutation

Outbreak

Prevention

Public health

receptor binding

domain

Remdesivir

Safety

Therapeutics

vaccine hesitancy
15 
5

Receptor binding

Domain

Remdesivir

Safety

Therapeutics

Vaccine hesitancy

Chloroquine

COVID-19 pandemic

Infectious diseases

MERS

Molecular dynamics

Trained immunity

Virology
10

15

20

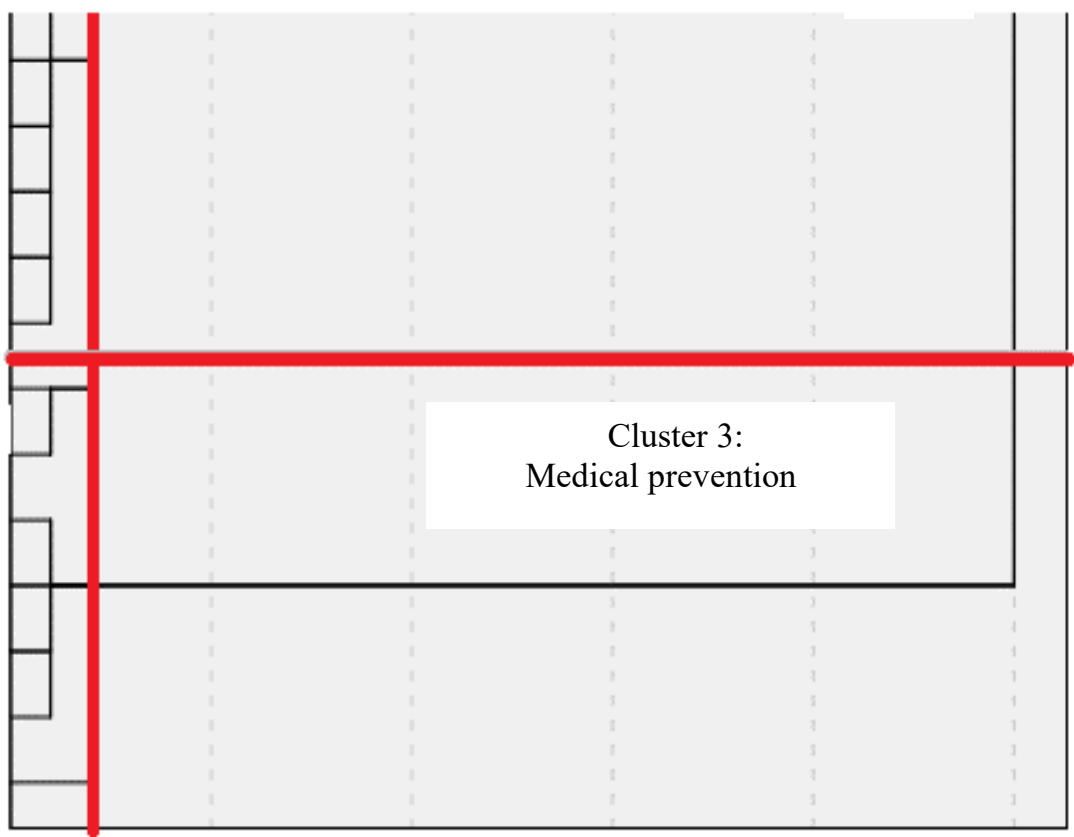

Figure 2. Hierarchical clustering of studies on COVID-19 vaccine in the world

According to Figure 2, the keywords of studies formed three clusters, which will be discussed in the following parts.

\section{Cluster 1: vaccine development strategy.}

The results of the co-word analysis showed that cluster 1 was the largest cluster with keywords ACE2, Antibodies, BCG, Cancer, Immune response, Infection, Clinical trial, Convalescent plasma playing role in the formation of this cluster.

\section{Cluster 2: immunotherapy.}

The keywords of this cluster, including Adjuvant, Epitope, Immunology, Prevention, Remdesivir, Safety, Vaccine hesitancy, and Immunization indicated that this cluster could be named as immunotherapy.

\section{Cluster 3: medical prevention.}

Considering the identification and evaluation of the subjects in cluster 3, such as Trained immunity, Virology, MERS, COVID-19 pandemic, and Chloroquine, the name medical prevention seemed suitable.

Following forming a matrix for each of the clusters and entering in the UCINET software, the centrality score and density of clusters were determined and a strategic chart was drawn using these scores (33). The scores of density and centrality are presented in Table 3. It should be noted that the origin was set at 10.88 and 0.52 considering the mean centrality and clusters density, respectively.

Table 3. Density and centrality of clusters obtained from the co-word analysis of studies in the world

\begin{tabular}{|c|ccc|}
\hline Cluster number & Cluster title & Density & centrality \\
\hline $\mathbf{1}$ & Vaccine development strategy & 0.57 & 22.47 \\
\hline $\mathbf{2}$ & Immunotherapy & 0.42 & 8.42 \\
\hline $\mathbf{3}$ & Medical prevention & 0.58 & 1.75 \\
\hline
\end{tabular}

The first cluster, the vaccine development strategy cluster, had the highest centrality of 22.47 and the third cluster had the highest density of 0.58 . In other words, the first cluster, which has the most repeated keywords has the highest centrality in terms of penetration, relation with other subjects, and links. In the strategic chart, the horizontal and vertical axes indicate centrality and density, respectively. 


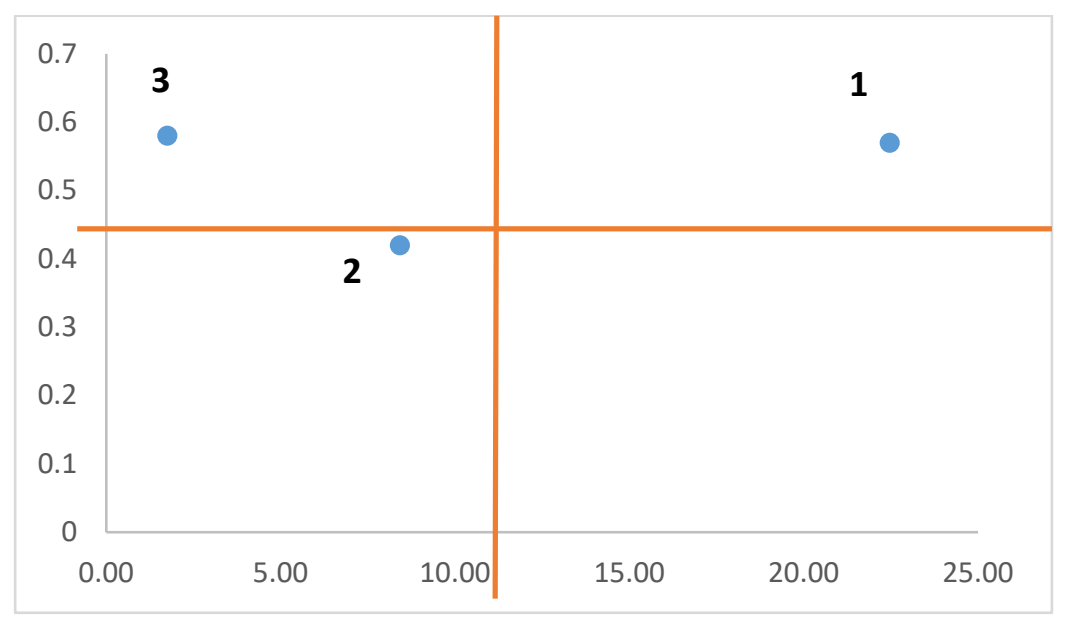

Figure 3. Strategic chart of studies on COVID-19 vaccine in the world

Considering the variation in the subjects of this field and the drawn strategic chart (Figure 3 ), clusters are in the regions of first, second, and third. As the strategic chart shows, cluster one is located in the first region and cluster three is located in the second region. It is noteworthy that clusters in the second region are not central but are developed. However, they are in a lower rank, compared to the clusters located in the first region. Cluster 2, located in the third region, was in the lowest rank in terms of importance and effect in the research field. In other words, the clusters in the third region are emergent and might be eliminated because they are less important subjects and attract less attention due to low centrality and density.
B. Iran studies: Following the co-word analysis of studies in Iran on the COVID-19 vaccine, seven clusters of words and concepts were identified. The research with the highest citations titled "COVID-19, an emerging coronavirus infection: advances and pros-pects in designing and developing vaccines, immunetherapeutics, and therapeutics" conducted by "Sharun, K; Dhama, K; Tiwari, R; Dadar, M Malik, YS; Singh, KP; Chaicumpa, W" in journal Human Vaccines \& Immunothera-peutics was published in 2020. Figure 4 demons-trates the concepts map of Iran's studies on COVID.

In the next step, the dendrogram (hierarchical clustering) of the research subjects in Iran was drawn.

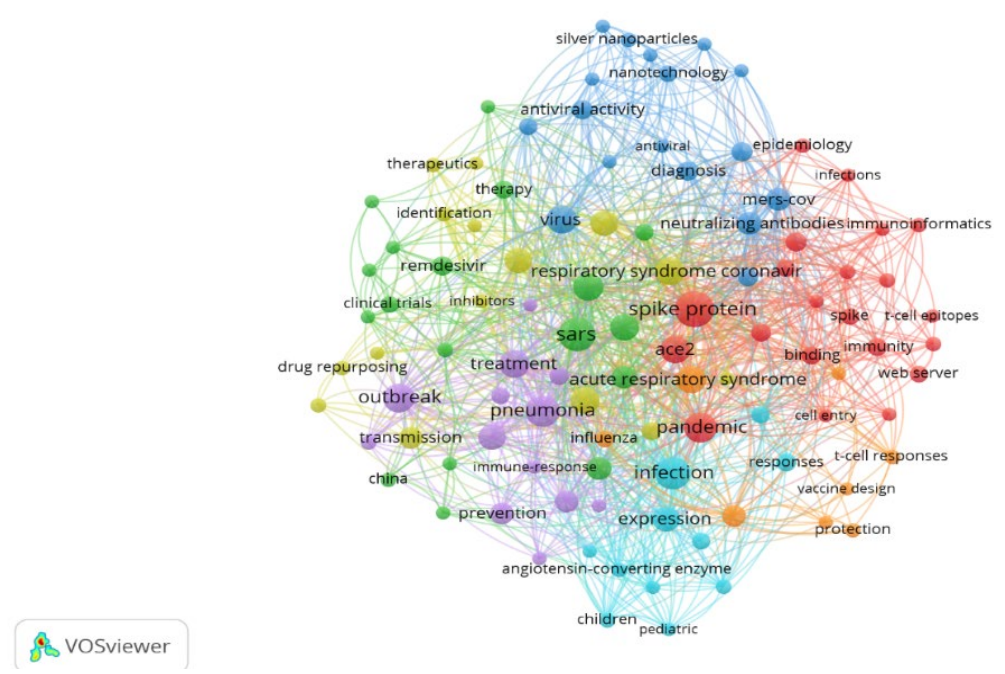

Figure 4. Concepts and subject clusters of studies on COVID-19 vaccine in Iran 


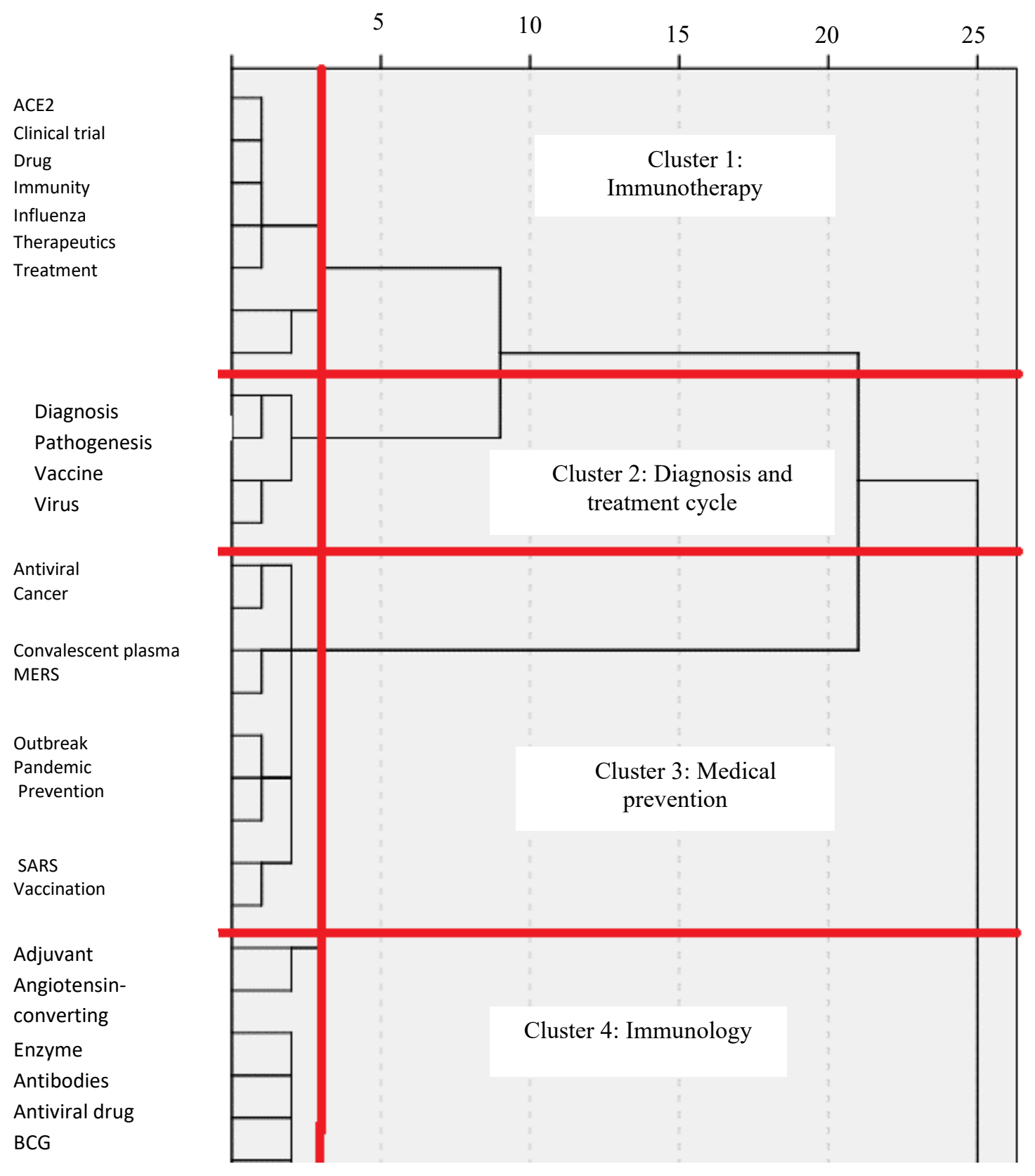


Child

Chloroquine

Corona

Coronavirus infection

COVID-19 pandemic

COVID-19 vaccine

Cytokine storm

Drug repositioning

Epidemic

Epidemiology

Epitope

Hydroxychloroquine

Immune response

Immunization

Immunoinformatic

Immunology

Immunotherapies

Infection

Infectious disease

Inflammation

Innate immunity

Knowledge

Molecular docking

Molecular dynamics

Mortality

Mutation

Neutralizing antibodies

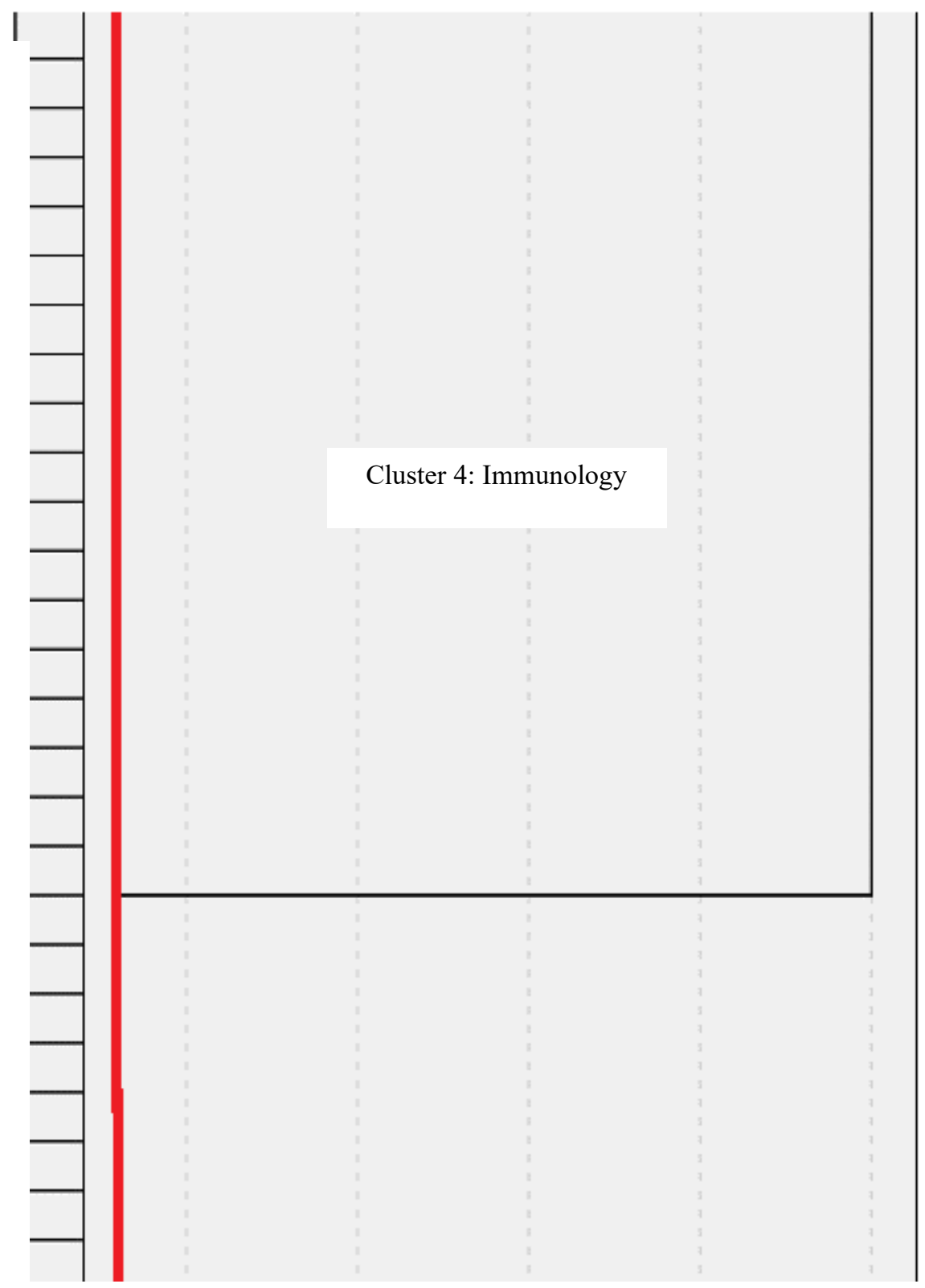




Mutation
Neutralizing antibodies
Pneumonia
Public health
Receptor binding domain
Remdesevir
Safety
Serology
Social distance
Spike (S) protein
Spike glycoprotein
T cell
Trained immunity
Vaccine
Vaccine development
Vaccine hesitancy
Virology

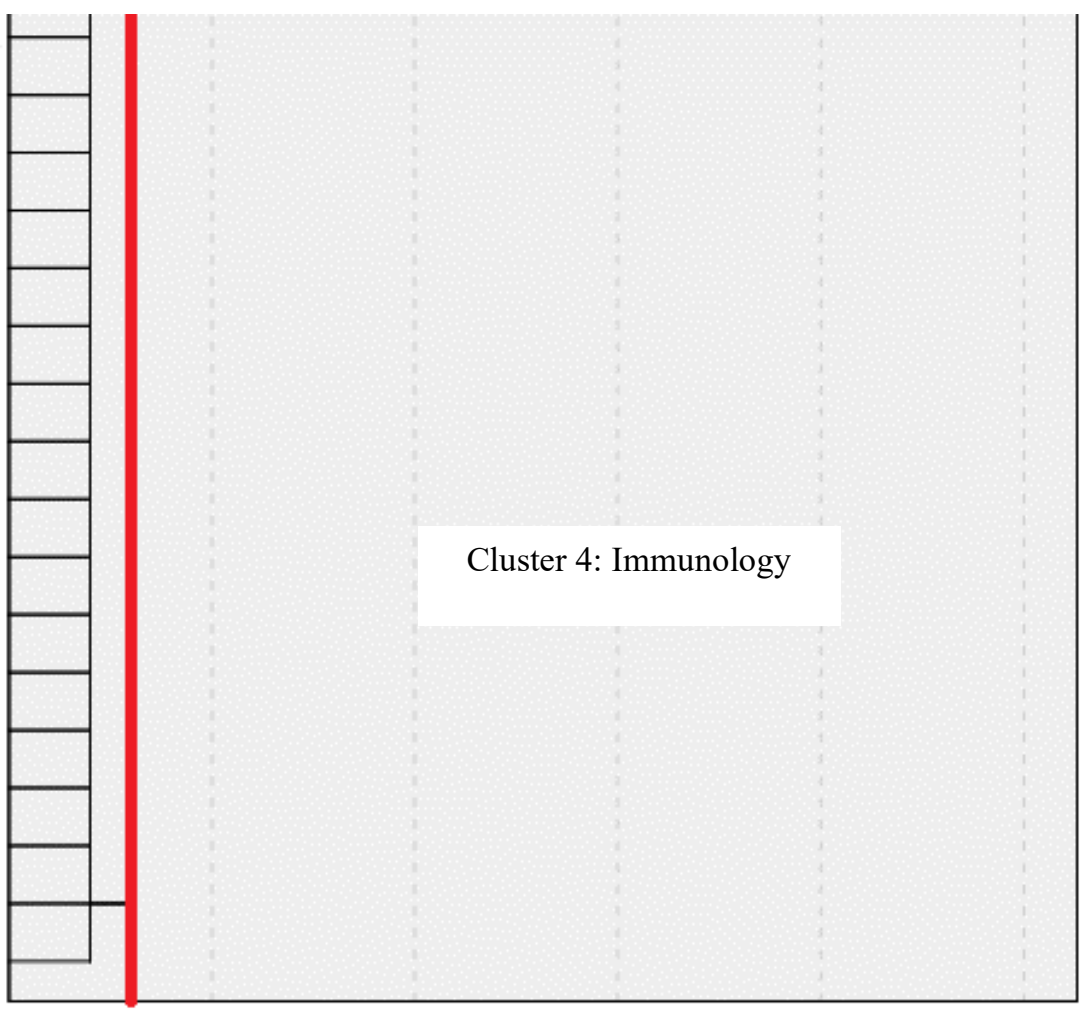

Figure 5. Hierarchical clustering of studies on COVID-19 vaccine in Iran

As demonstrated in Figure 5 , the keywords of evaluated investigations formed four clusters.

\section{Cluster 1: immunotherapy.}

The results of the co-word analysis revealed that keywords ACE 2, Clinical trial, Drug, Immunity, Influenza, Therapeutics, and Treatment played role in the formation of cluster 1 .

\section{Cluster 2: diagnosis and treatment cycle.}

The keywords of the smallest cluster, including Diagnosis, Pathogenesis, Vaccine, and Virus indicated that this cluster could be regarded as diagnosis and treatment cycle.

Cluster 3: medical prevention.
The evaluation of subjects in cluster 3 , such as Antiviral, Cancer, Convalescent plasma, MERS, Outbreak, Pandemic, Prevention, SARS, and Vaccination demonstrated that medical prevention was a suitable name.

\section{Cluster 4: immunology.}

The name immunology seemed suitable for this cluster based on 49 subjects in cluster 4, including Adjuvant, Angiotensin-converting enzyme, Antibodies, Antiviral drug, BCG, Chloroquine, Cytokine storm, Hydroxychloroquine, Immunization, Immunoinformatic, Immunology, and Immunotherapies.

The scores of density and centrality of clusters are shown in Table 3. It should be noted that the origin of the graph was set at 2.08 and 0.79 considering the centrality mean and clusters density, respectively.

Table 4. Density and centrality of the clusters obtained from the co-word analysis of Iran studies

\begin{tabular}{|c|ccc|}
\hline Cluster number & Cluster title & Density & 0.66 \\
\hline $\mathbf{1}$ & immunotherapy & 1 & 1.33 \\
\hline $\mathbf{2}$ & diagnosis and treatment cycle & 0.5 & 2 \\
\hline $\mathbf{3}$ & medical prevention & 1 & 1 \\
\hline $\mathbf{4}$ & immunology & 1 \\
\hline
\end{tabular}


The third cluster or medical prevention had the highest centrality of 4 and clusters two and four had the highest density of 1 . It means that the third cluster, which has the most repeated keywords has the highest centrality in terms of penetration, relation with other subjects, and links with other keywords. In the strategic chart, the horizontal axis indicates centrality and the vertical axis shows density. The strategic chart is drawn based on the mentioned scores.

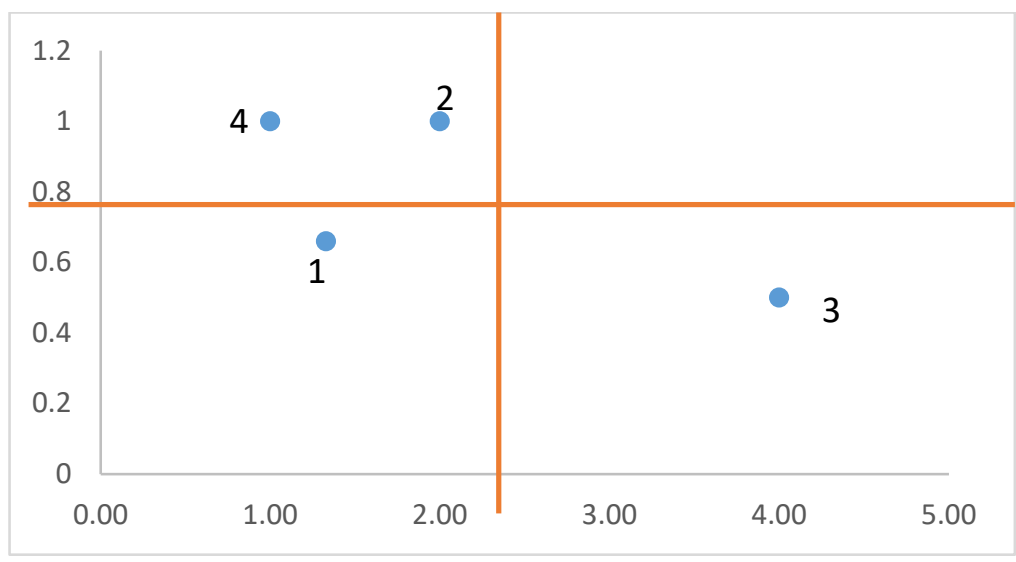

Figure 6. Strategic chart of studies on COVID-19 vaccine in Iran

According to Figure 6, clusters are in the second, third, and fourth regions with clusters two and four being located in the second region. The clusters of the second region are not central but developed. However, these clusters are in a lower rank than the clusters of the first region. Cluster one located in the third region is in the lowest rank regarding importance and effect in the intended research field. In other words, clusters in the third region are emergent because have a low centrality and density and have attracted low attention. The third cluster is located in the fourth region of the strategic chart. Clusters in the fourth region of the chart are central clusters but are not developed and matured yet.

In the next step of the study, the institutes and authors of all studies extracted from WOS based on being from Iran or other parts of the world were entered in VOSviewer software for drawing scientific collaboration maps in the COVID-19 vaccine domain. Here, you can find the map of scientific collaboration in studies performed in Iran and the world.

\section{World studies}

five clusters of countries were identified following the co-authorship analysis of the studies at the level of the cooperation of countries in this field in the world (Figure 7).

\section{Studies in Iran}

five clusters of countries were identified in the coauthorship analysis of studies at the level of the cooperation of countries in this field in Iran (Figure 8).

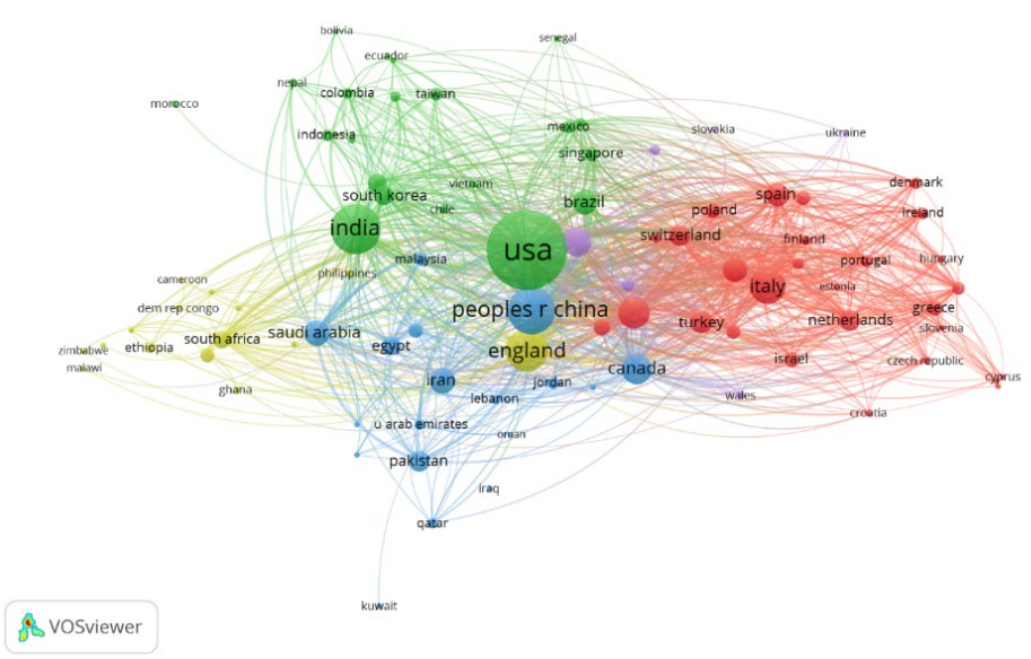

Figure 7. Map of the scientific collaboration of countries in studies on COVID-19 vaccine in the world 


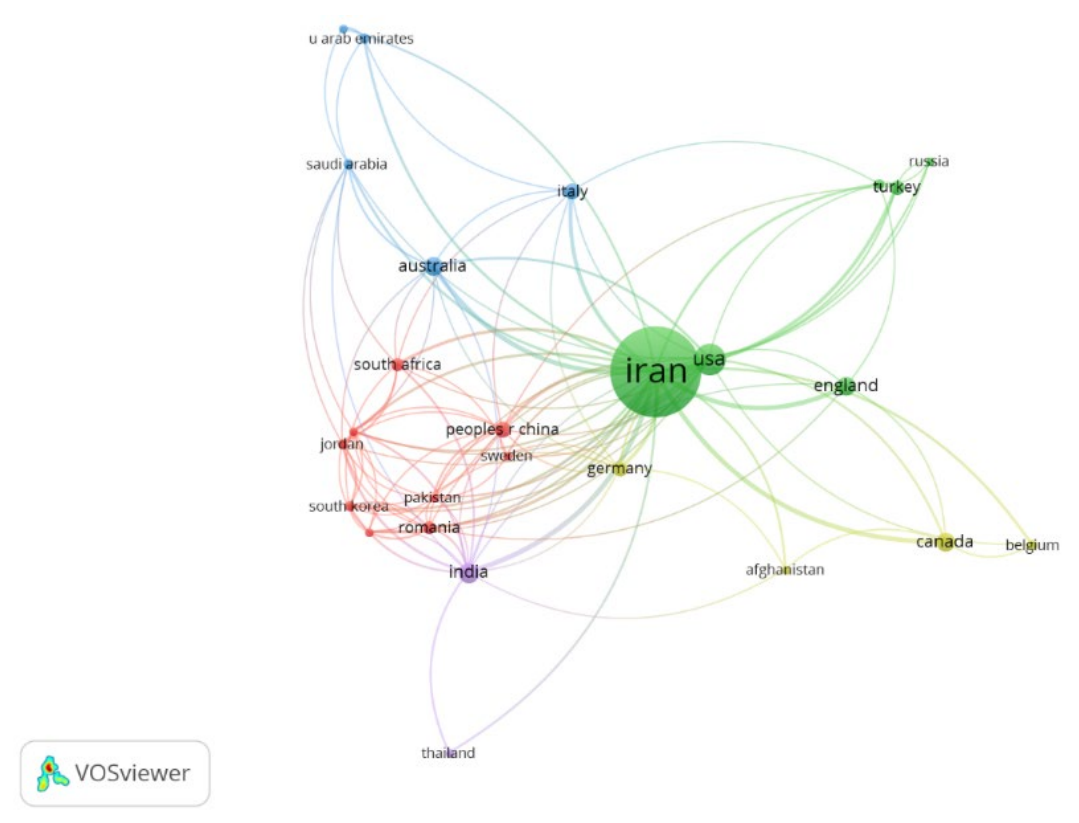

Figure 8. Map of the scientific collaboration of countries in studies on COVID-19 vaccine in Iran

We present the map of the scientific collaboration of institutes in studies in Iran and other parts of the world.

\section{Studies in the world}

Seventeen clusters, including the scientific centers and institutes, were recognized based on the coauthorship analysis of studies at the level of the cooperation of organizations in this domain in the world (Figure 9).

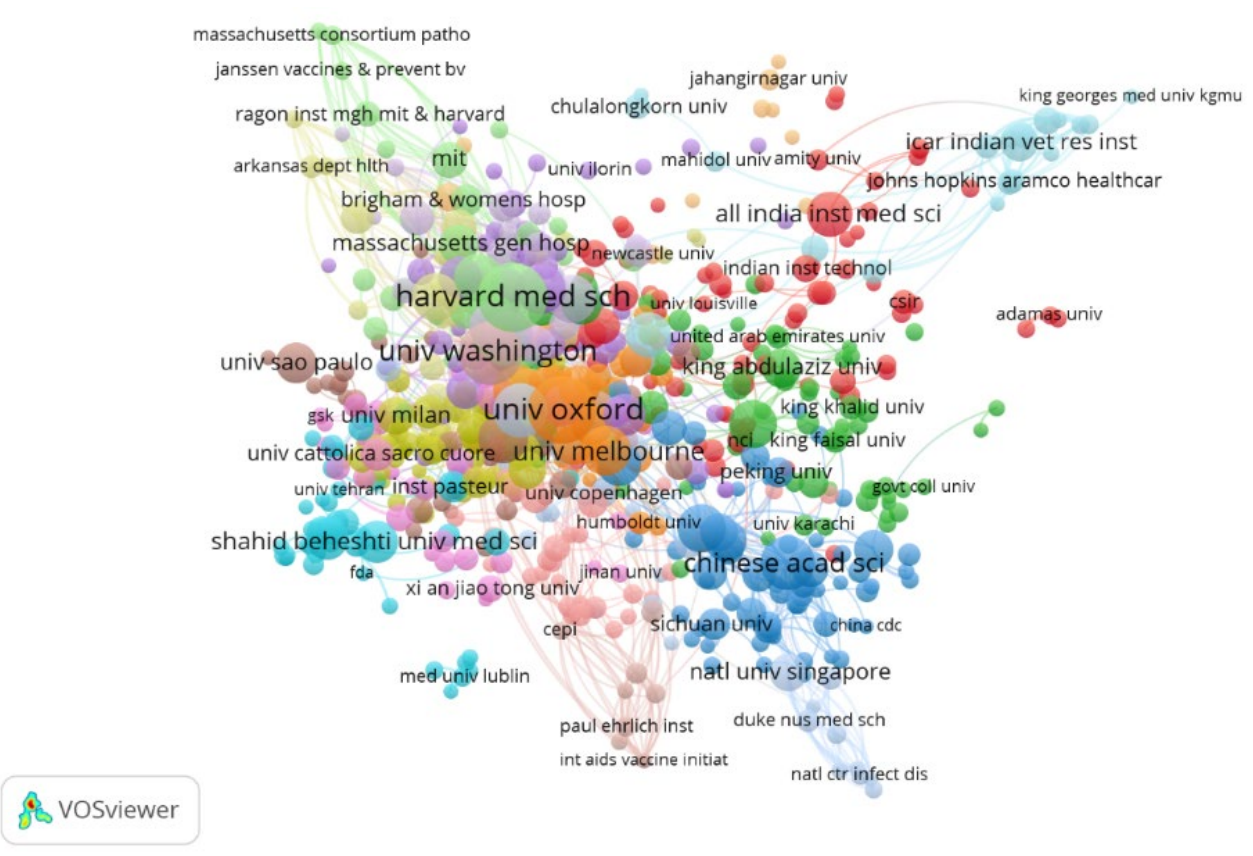

Figure 9. Map of the scientific collaboration of organizations in studies on COVID-19 vaccine in the world

\section{Studies in Iran}

Ten clusters of the involved scientific centers and institutes were recognized based on the co-authorship analysis of studies at the level of the cooperation of organizations in this domain in the world (Figure 10). 


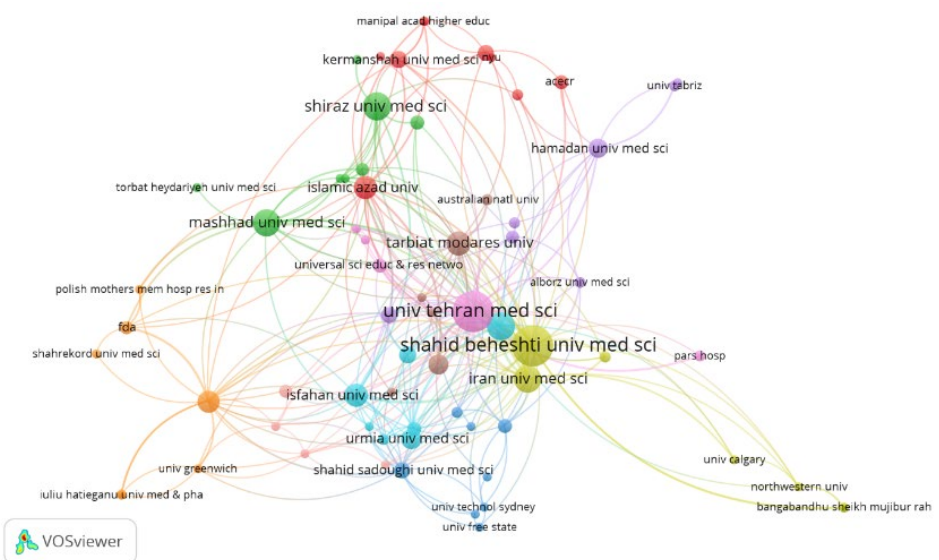

Figure 10. Map of the scientific collaboration of organizations in studies on COVID-19 vaccine in Iran

We present the map of the scientific collaboration of researchers in studies in the world and Iran.
Ten clusters of authors were identified based on the co-authorship analysis of studies in this domain in the world at the level of authors' cooperation (Figure 11).

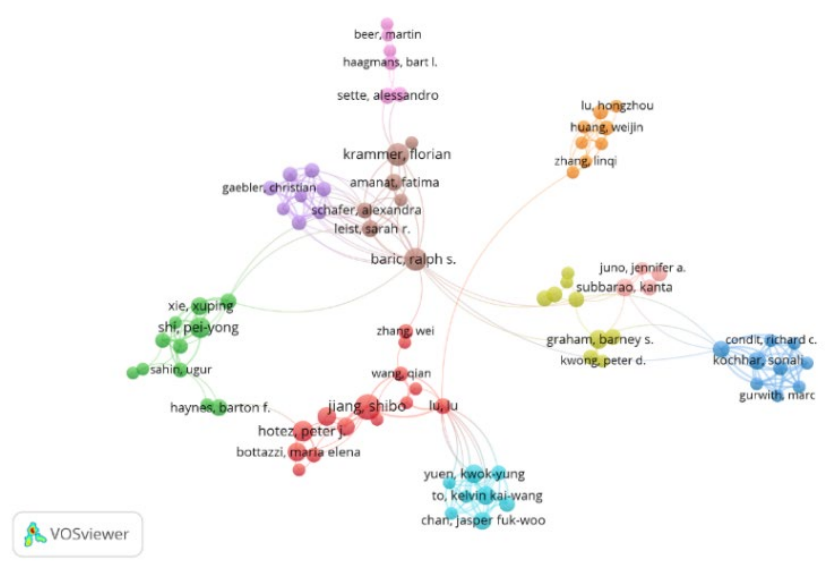

Figure 11. Map of the scientific collaboration of researchers in studies on COVID-19 vaccine in the world

\section{Studies in Iran}

Sixteen clusters of authors were identified based domain in the world at the level of authors' on the co-authorship analysis of studies in this cooperation (Figure 12).

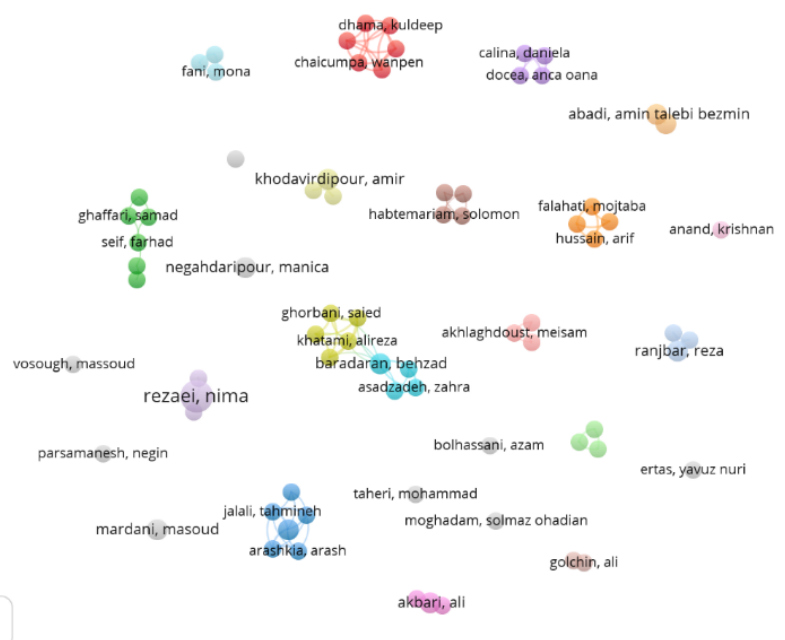

Figure 12. Map of the scientific collaboration of researchers in studies on COVID-19 vaccine in Iran 
The authors of studies on COVID-19 vaccine in the world were analyzed based on centrality indices, relations, and the social network developed between researchers using the VOSviewer software along with Bibexcel and Gephi (Table 5). One of the useful indices for the analysis of social networks is Freeman centrality, including degree centrality, closeness centrality, and betweenness centrality. Centrality shows the types and number of the relations of a network member with other network members (34). Degree centrality is an indicator node of the number of links with other nodes in the network $(35,36)$.

Closeness centrality assesses the distance of a node with other nodes in the network and indicates the mean length of the shortest pathway between that node and other nodes in the network (34). Between- ness centrality of a node is the times a node is located between the shortest pathways between node pairs. Nodes with high betweenness centrality in a premium situation play the role of a broker for linking the nodes and groups. It is regarded as a strength index that directly and indirectly controls the data in the network.

Moreover, the value of betweenness centrality is 0 1. In 0 condition, nothing happens in the network by eliminating the node and all nodes remain linked and even the short distances between them are not eliminated. However, in condition 1 , the node is in a strategic situation, which can be a candidate turning point with a unique situation (37). Table 5 shows the five best world researchers in this field based on each of the centrality indices.

Table 5. Five best researchers of studies on COVID-19 vaccine in the world based on centrality indices

\begin{tabular}{|c|cccc|c|}
\hline Researcher & degree Centrality & Researcher & $\begin{array}{c}\text { closeness } \\
\text { Centrality }\end{array}$ & Researcher \\
\hline Dhama K & 30 & lacobucci G & 1 & 1815.93 \\
\hline Tiwari R & 22 & Mahase E & 1 & Khan S & 1475.12 \\
\hline Kumar P & 20 & Liu Y & 0.34 & Atyeo C & Baric RS \\
\hline Malik YS & 20 & Shi PY & 0.31 & Shi PY \\
\hline Patel SK & 18 & Wang L & 0.31 & 976.14 \\
\hline
\end{tabular}

Some of the important indices in the scientific collaboration network of the world are reported here.
The five best Iranian researchers in this field are presented in Table 7 in the order of centrality indices.

Table 6. Important indices in the scientific collaboration network of the world

\begin{tabular}{|c|c|}
\hline Average Degree & $7 / 274$ \\
\hline$H$ index & 8 \\
\hline Network density & 0.059 \\
\hline Ratio of components & 0.059 \\
\hline Components & 5 \\
\hline Network connection & 0.867 \\
\hline Network focus & 0.153 \\
\hline Network separation & 0.133 \\
\hline Standard deviation distance & 1.984 \\
\hline Network diameter & 11 \\
\hline Average route length in the network & 4.295 \\
\hline Network compression & 0.273 \\
\hline Network size & 0.727 \\
\hline
\end{tabular}


Table 7. Five best Iranian researchers on COVID-19 vaccine based on centrality indices

\begin{tabular}{|c|cccc|c|}
\hline Researcher & $\begin{array}{c}\text { degree } \\
\text { Centrality }\end{array}$ & Researcher & $\begin{array}{c}\text { closeness } \\
\text { Centrality }\end{array}$ & Researcher \\
\hline Mansournia & 48 & Akbari & Nabavi & 1 & Mansournia \\
\hline Soltani & 48 & Ghaffari & 1 & 1 & Baradaran \\
\hline Rezaei & 46 & Hedayati & Eftekhari & Nosrati \\
\hline Sahebkar & 46 & Sharifi & 1 & Rezaei \\
\hline Jalali Nia & 44 & & 1 & 20.1 \\
\hline
\end{tabular}

Some of the important indices in the scientific collaboration network of researchers in Iran are reported here.

Table 8. Important indices in the scientific collaboration network of researchers in Iran

\begin{tabular}{|cc|}
\hline Average Degree & 6.268 \\
\hline H index & 20 \\
\hline Network density & 0.065 \\
\hline Ratio of components & 0.281 \\
\hline Components & 28 \\
\hline Network connection & 0.224 \\
\hline Network focus & 0.189 \\
\hline Network separation & 0.776 \\
\hline Standard deviation distance & 1.454 \\
\hline Network diameter & 8 \\
\hline Average route length in the \\
network
\end{tabular}

\section{Discussion}

Our results demonstrated that during 2019-2021, 6005 studies by 29473 authors affiliated to 7988 scientific institutes from 147 countries were indexed in the WOS. Iran with 196 related studies by 1583 authors affiliated to 635 universities and scientific institutes with the cooperation of 76 countries has the tenth-ranked among the involved countries. Investigations in the world have been identified to have diverse designs. According to Table 1, more than $80 \%$ of publications were in journals and other studies were recorded in the "others" group.

Furthermore, data analysis revealed that the dominant language for science production in this domain is English and covers $97.2 \%$ of the studies. In addition to English, research in this field has been published in 14 other languages, the most important of which are German (0.8\%), Spanish (0.7\%), and French (0.3\%). On the other hand, the evaluation of studies in Iran demonstrated that all were published in English and four designs of "evaluation, article, editor's note, and letter to the editor". Harvard Medical School and the University of Oxford in the world and Shahid Beheshti University of Medical Sciences and Tehran University $f$ Medical Sciences in Iran had the highest cooperation. K. Dhama and E. mahase in the world and N Rezaei and ATB Abadi in Iran had the most studies. United States department of health human services provided the best financial support of researches in this field in the world and Tehran University of Medical Sciences provided the best support in Iran.

Co-word clustering of the studies in the world and Iran on COVID-19 vaccine using the VOSviewer led to the formation of seven clusters. Four out of these seven identified clusters (yellow, green, red, and purple) entailed diverse concepts and words, namely "Infection, Pneumonia, Pandemic, Spike protein, SARS, Protein, Transmission, Chloroquine, Convalescent plasma, and ACE 2". Therefore, these clusters were in a central and remarkable position because of repeated and common keywords with the most important interests of researchers of this domain in the world being in this cluster. Three of the seven clusters identified in Iran studies (blue, red, and purple) encompassed keywords "Spike protein, SARS, Infection, Pneumonia, Pandemic, Treatment, Convalescent plasma, ACE 2, and Cytokine storm" had a central and considerable position.

Hierarchical clustering in investigations in the world resulted in the formation of three clusters, including vaccine development approach, medical prevention, and immunotherapy. Among the three identified clusters related to world studies, the clusters vaccine development strategy and medical prevention were developed. On the other hand, the immunotherapy cluster is an emergent cluster with less important clusters that attract less attention. The hierarchical clustering in studies in Iran led to four clusters, namely immunotherapy, diagnosis and treatment cycle, medical prevention, and immunology.

Among four identified clusters, "diagnosis and treatment cycle" and "immunology" clusters were 
developed but not central clusters. On the other hand, the immunotherapy cluster is emergent with less important subjects. The medical prevention cluster is central but not developed. In other words, this cluster is not mature yet.

Scientific collaboration in the country at the level of world and Iran studies led to five clusters. Although the USA, India, and China had most investigations, most links were for England and the USA, as shown in Figure 3. Moreover, clusters green and blue are of a central role because remarkable nations are in these clusters. It is noteworthy that Iran, China, Canada, and Saudi Arabia are in the same cluster. Iran cooperated with 76 countries in this field. In addition, Iran had the most cooperation with the USA and India in this domain.

Furthermore, the results of the current study revealed that 17 and 10 clusters resulted from scientific collaboration at the level of institutes in the world and Iran, respectively. According to Figure 5, most studies and links were related to the University of Oxford and Harvard Medical School. Clusters orange, green, and pink were in a central and important position because active institutes were in these clusters. In terms of citation, the three institutes National Institute of Allergy and Infectious Diseases, Fred Hutchinson Cancer Research Center, and Pasteur Institute were in the third ranks.

In the domain of Iran studies, although Tehran University of Medical Sciences and Shahid Beheshti University of Medical Sciences equally had the most studies and relationships, Shahid Beheshti University of Medical Sciences received the highest citations. As could be seen in Figure 6, clusters yellow and pink are regarded among important and central clusters due to possessing active Iranian institutes. Moreover, 10 and 8 clusters were formed by scientific collaboration at the level of researchers in studies in the world and Iran, respectively.

In the network of the cooperation of world researchers, although K. Dhama and E. Mahase had the most investigations and $\mathrm{S}$. Ralph had the most studies and links. Regarding citations, S. Jason with seven investigations was in the first rank. Clusters brown and red were the important and central clusters in the cooperation of researchers due to the best researchers being in these clusters. According to the findings, K. Dhama, R. Tiwari, and P. Kumar had the best ranks in terms of centrality among world researchers.

In terms of closeness centrality, G. Iacobucci, E. Mahase, and Y. Liu had the best ranks. In addition, Y. Liu, S. Khan, and C. Atyeo were ranked 1-3 in betweenness centrality. In the cooperation network of researchers in Iran, Nima Rezaei received the most citations. Amin Talebi and Farid Rahimi made more relations, compared to other researchers, and formed a cluster with two nodes. However, other clusters had one member. Among Iran researchers, Mansournia, Soltani, and Rezaei had the highest centrality, and Akbari, Nabavi, and Ghaffari had the highest closeness centrality. Furthermore, Mansournia, Baradaran, and Eftekhari had the highest betweenness centrality.

Concerning the remarkable countries in the production and publication of studies, the results of the present investigation were in line with the findings of Surulinathi et al. (27) and Ahmad et al. (29). In addition, our results in terms of active researchers and institutes in this field were consistent with the findings of Ahmad et al. (29) and Ay et al. (30). In terms of the location of published studies and active institutes in the COVID-19 vaccine domain, the findings of the current investigation were congruent with the research of Ahmad et al. (29). Immunology, internal medicine, and experimental medical studies had the highest share in COVID-19 studies, especially in Iran. The latter finding is also consistent with the study performed by Ay et al. (30).

\section{Conclusion}

Considering the high prevalence of COVID-19 and increased mortality throughout the world, research on the COVID-19 vaccine in different aspects has become the priority of governments, scientific centers, and researchers in the world. Analysis and comparison of studies in the world and Iran in the field of COVID-19 vaccine in terms of subject and scientific collaboration lead to a better understanding of involved groups aimed to elevate investigations quantitatively and qualitatively followed by COVID-19 control in the shortest possible time. In other words, subjective analysis of studies and scientific collaboration can clarify the common subjects, in addition to identifying the existing limitations and activists. Consequently, the present situation is understood, and scientific, managerial, and executive policies are enhanced. As a result, novel research pathways might emerge.

Considering the importance of the COVID-19 vaccine and the published studies in this field, practical steps could be taken to further benefit in line with the international science borders. Some of these steps may entail identifying distinct aspects, procedures, tools, and technologies in the field of the COVID-19 vaccine based on the recognized words and concepts. Afterwards, planning and preparation could be completed using these steps in related execution and research projects. Based on the current study, the following recommendations could be made for future studies:

Subjective analysis of studies in this field in other indexing databases, such as Scopus and Google 
Scholar to evaluate research in this domain in the world and Iran comprehensively.

Analysis of the content, concepts, and words of scientific documents related to COVID-19 vaccine in scientific databases in Persian in Iran and comparison of the structure of studies in Iran and the world.

Analysis of the content, concepts, and words of scientific documents in obtained domains and clusters from Iran and the world to identify the existing limitations.

\section{Acknowledgment}

We would like to extend our gratitude to Dr. Alireza Norouzi who guided the authors of the present study.

\section{Conflict of Interest}

The authors did not report any conflict of interest. 


$$
\begin{aligned}
& \text { مجله ميكروبشناسى يزشكى ايران }
\end{aligned}
$$

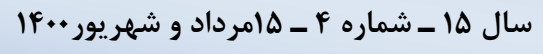

$$
\begin{aligned}
& \text { Journal homepage: www.ijmm.ir }
\end{aligned}
$$

مطالعه بِزوهشهاى مرتبط با واكسن كوويد 19 در ايران و جهان:

\section{تحليل موضوعى و همكارىهاى علمى}

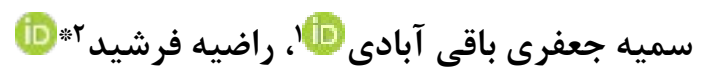

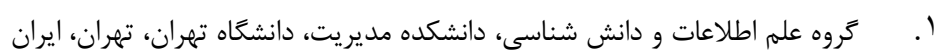

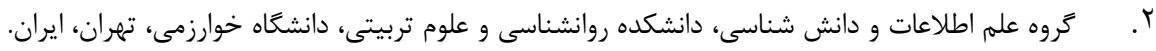

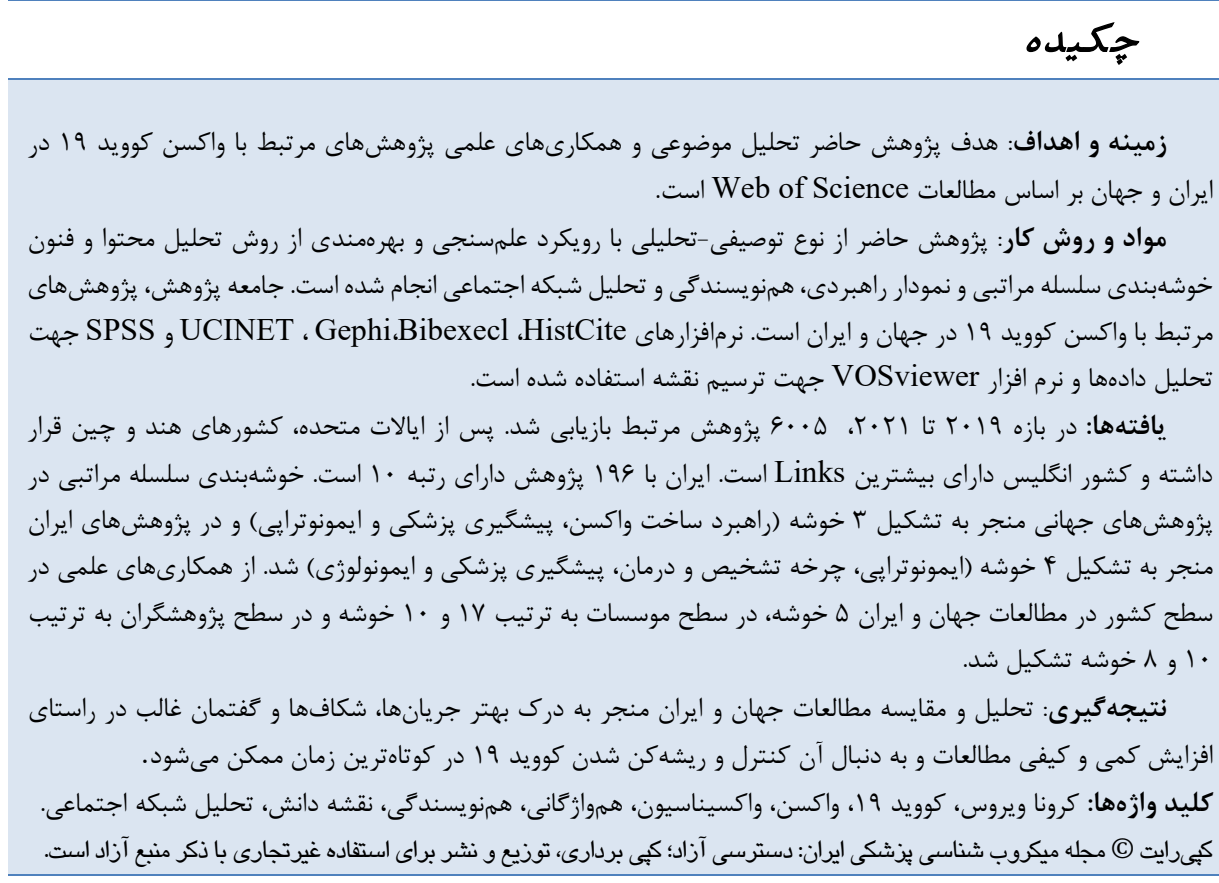

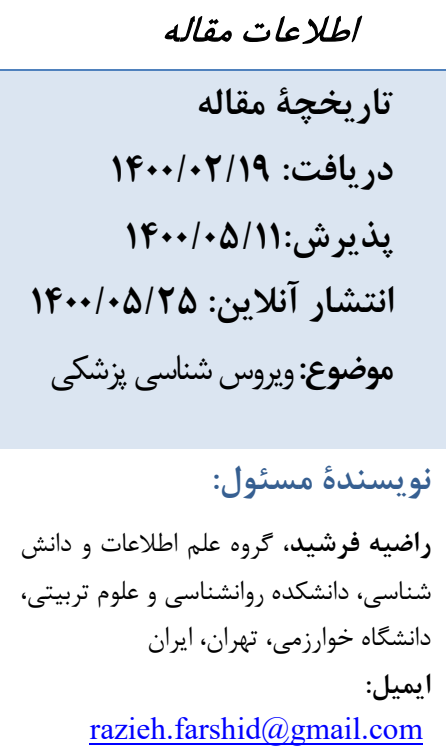

razieh.farshid@gmail.com
كروناويروس، از جمله ويروسهايى است كه ابتدا در ميان حيوانات و سيس در ميان انسانها منتقل شده و نامكَذارى آنها به آنه دليل Protein spikes) Crownlike spikes است كه از سطح مان آنها بيرون آمده و شبيه به تاج خورشيد است (و V). علائم اين بيمارى

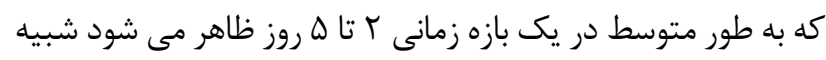

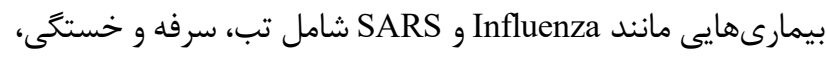

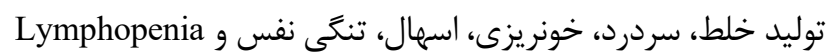

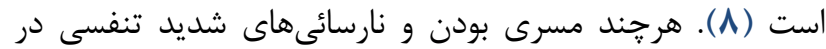

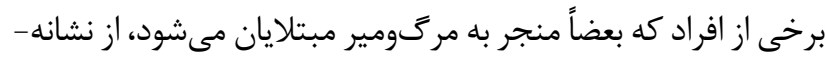

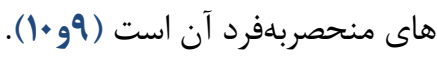

SARS- بس از شناسايى كرونا ويروس جديد يا اصطلاحا در شهر ووهان استان هوبى در جين با تاييد WoV-2

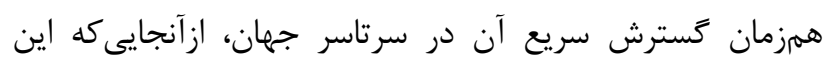

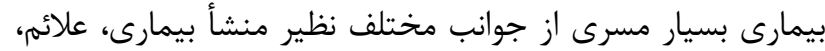
روشهاى انتقال و شيوع، بيشخيرى و تشخيص، راههاى درمان، داروهاى موثر، ميزان مركىومير، ساخت واكسن و ... بسيار ناشناخته

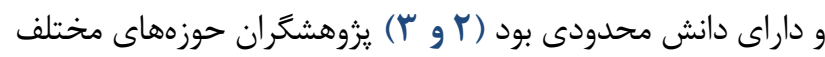

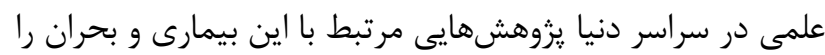

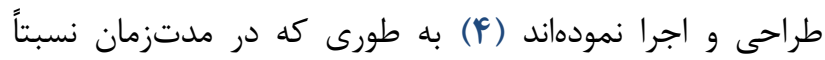
كوتاهى، تعداد يزوهشهاى مرتبط در Citation Databases معتبر

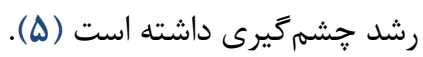


اجرايى فرمان امام خمينى (ره) و مؤسسه بركت، انستيتو ياستور

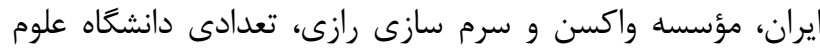
يزشكى، وزارت دفاع، شركتها و مؤسسات دانش بنيان و ... كار مارى

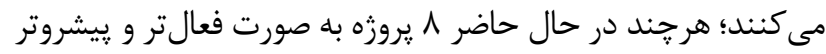

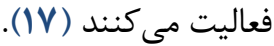

بدون شك در اين شرايط بحرانى حوزهاى زيادى از جمله IMMUNOLOGY BIOCHEMISTRY MOLECULAR BIOLOGY ‘RESEARCH EXPERIMENTAL MEDICINE ،VIROLOGY ‘PHARMACOLOGY PHARMACY ،MEDICINE RESEARCH INFECTIOUS DISEASES SARS- يزوهش و ساخت واكسن به منظور مقابله با بحران بيمارى

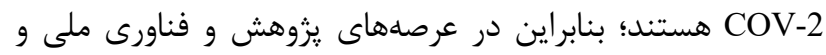
بينالملى، حوزهاى بينرشتهاى، همكارى هاى يزوهشى و همجنين

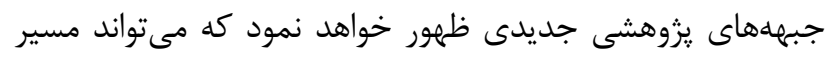

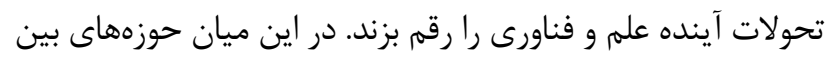
رشتهاى حاصل از مشاركتهاى علمى نوظهور مرتبطترين و و

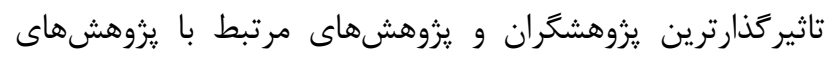

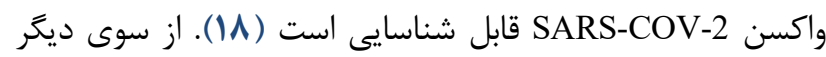
يروهشكران با اتكاء به يزوهشهاى انجام شده، آيندة علمى حوزء

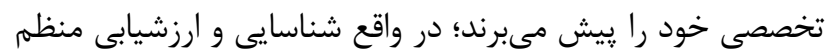

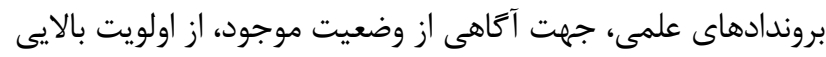

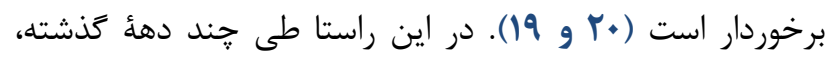

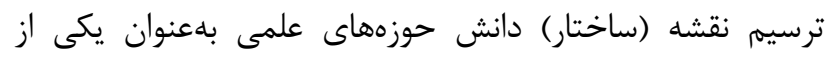
مهممترين وجوه مطالعات سنجش علم، اهميت بسيارى در حوزهاى لهاى مختلف علمى كسب كرده است (Iآ). مطالعات سنجش علم با هدف

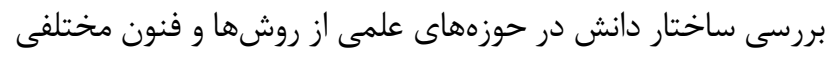

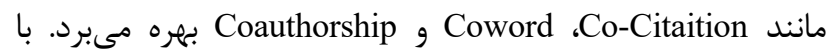
استفاده از تحليل هم|ستنادى مىتوان مفاهيم و خوشههاى اصلى در

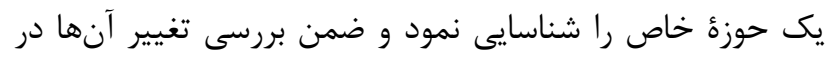

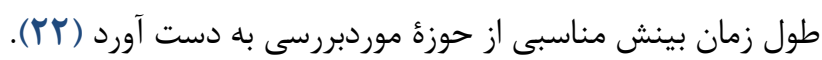

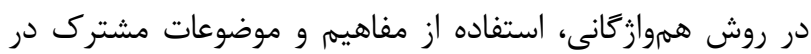
بخشهاى Title، Abstract ، Meywords و Text در توليدات علمى

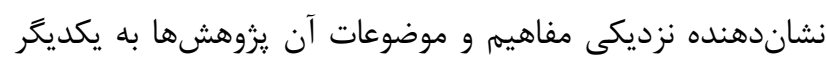

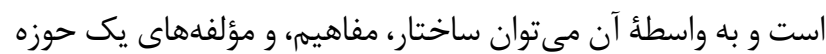

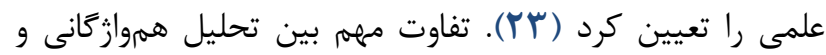
تحليل هم/ستنادى از نغاه He اين است كه تحليل هماستنادى به

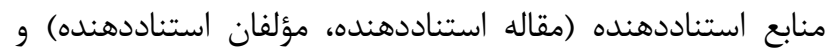
مأخذ استناد شده (مؤلف استناد شده، مدرك استناد شده) نيازمند
با توجه به افزايش بىرويه مبتلايان و مرك و مير از يك سو و عدم وجود درمانهاى موثر در بهبود قطعى اين بيمارى و وجود

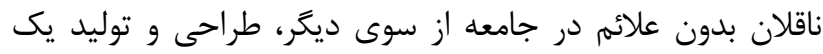

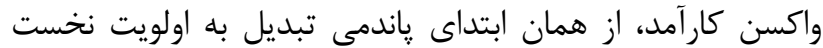

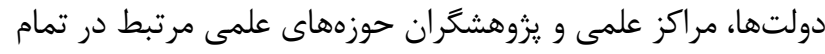

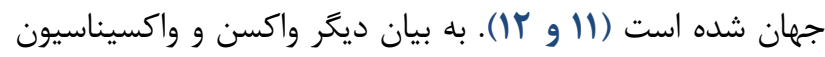

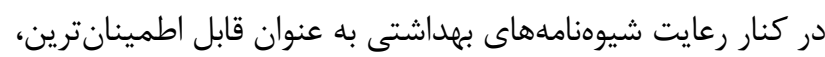
اقتصادىترين و موثرترين اقدام يیشخيرانه در برابر كشندهترين

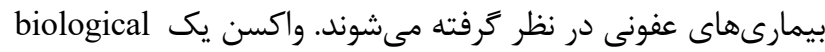
خاست كه ايمنى اكتسابى فعال نسبت به يك بيمارى

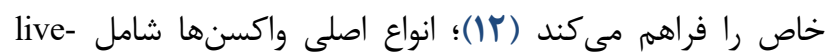
Subunit inactivated vaccine attenuated vaccine toxoid vaccine, conjugate, polysaccharide recombinant است (سا). در هنكام طراحى يك واكسن، در ابتدا بايد اطلاعات

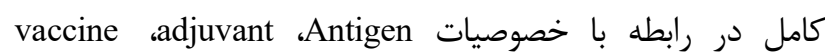
production and delivery system SARS-CoV- در دسترس بودن اطلاعات زنومى و ساختارى ويروس

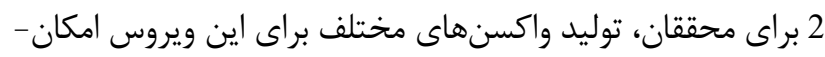

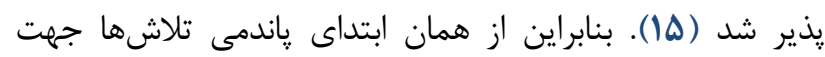

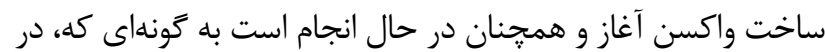
حال حاضر بيش از ·. ا واكسن در مرحله تست اثر بخشى آنها دان در حيوانات است، همجنين محققان، تعداد زيادى از آنها آنها را به به مرحله آنه Clinical trial تست رسيده است و تقريبا ها واكسن داراى مجوز و تاييد شده و

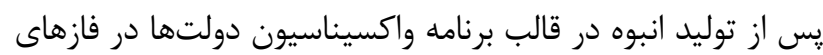

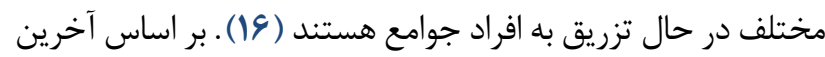
آمار جهانى 11 واكسن SARS-CoV-2 در فاز ب بالينى هستند. از جمله اين واكسنها اسيوتنيك روسيه، واكسن فايزر و مادرنا در

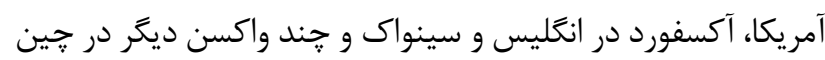
تائيديههاى تزريق را اخذ كردهاند. در اين راستا مطالعات زيادى از

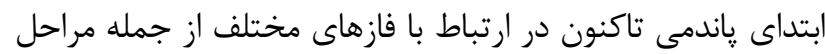

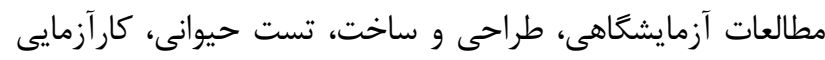

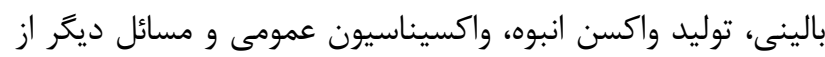

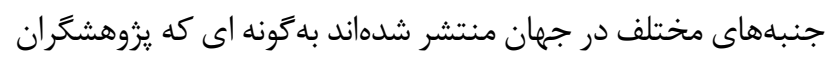
جمهورى اسلامى ايران نيز در اين مطالعات نقش موثرى داشتهاند.

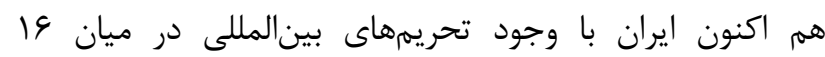
توليدكننده واكسن SARS-CoV-2 در دنيا (از نظر تعداد واكسن) در رتبه يازدهم قرار دارد. براساس اعلام مسئولان وزارت بهداشت، r آتم روى توليد واكسن SARS-CoV-2 در كشور نظير ستاد 
براى سه يزوهش، SCIENCE با rاع|F استناد براى سا يزوهش، THE NATIONAL ACADEMY OF SCIENCES OF توليدات THE UNITED STATES OF AMERICA

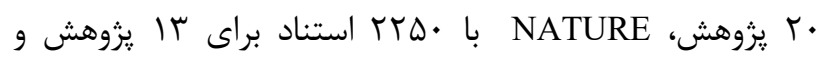

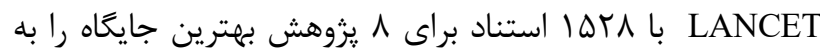

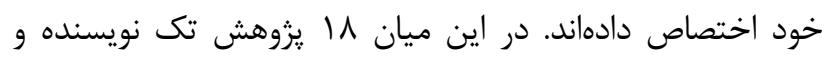

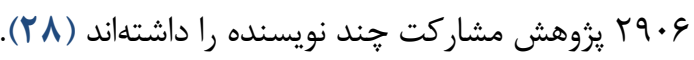

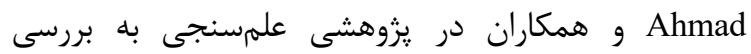
Research trends

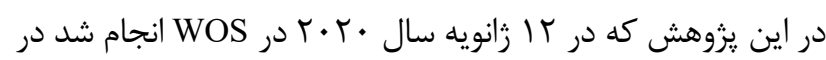

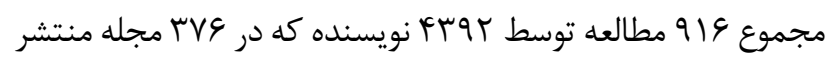

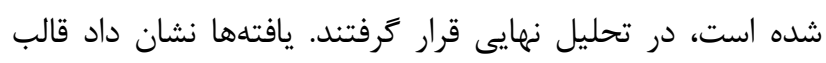

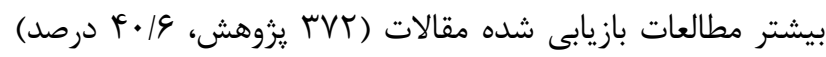

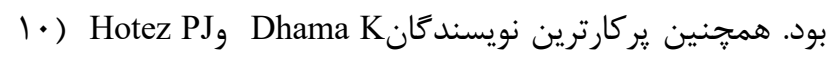
يزوهش، // درصد) بودند. فعالترين موسسه، دانشخاه آكسفورد

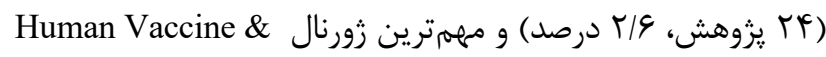
Immunotherapeutics كلمات كليدى19 COVID

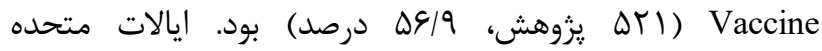

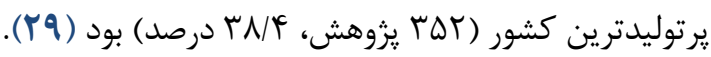

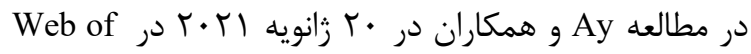

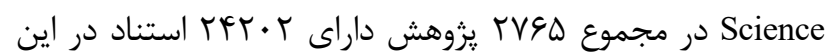
مطالعه دخيل بودند. ايمونولوزى، يزشكى عمومى داخلى و تحقيقات

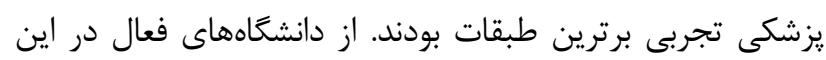

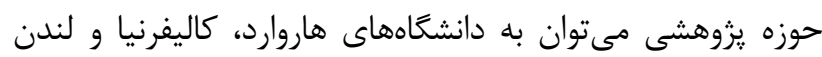

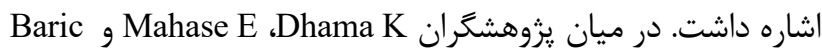
RS به ترتيب در بيشترين يزوهشها ئرونا مشاركت داشتهاند. نشريه 1, بالاترين تعداد مطالعات Biomolecular Structure Dynamics منتشر كرده است. كشور ايالات متحده فعالترين كشور در ميان

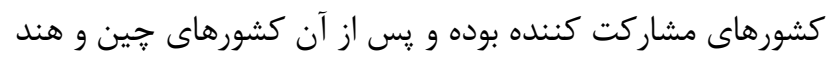
قرار دارند (•r).

بنابراين با توجه شيوع كسترده SARS-COV-2 و افزايش

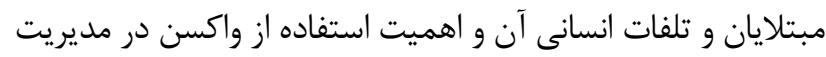

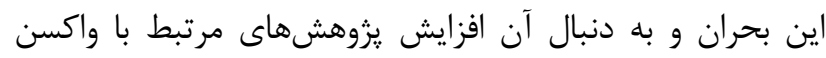
SARS-COV-2 مرتبط كه تنها به ارائه گزارش گونه از مطالعات اين حوزه يرداختهاند،

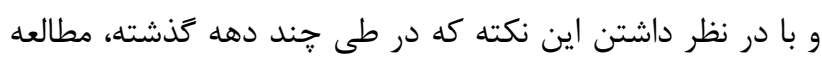

است (YY). از سوى ديخر در همكارىهاى علمى، مراكز يزوهشى-

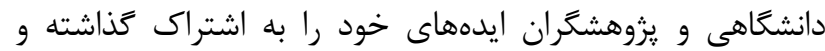
موجب كسترش كيفى و كمى توليدات علمى مىشوند (YQ).

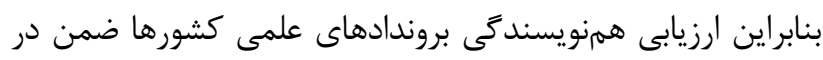
نظر داشتن ابعاد و وسعت همكارى علمى، كشورها، سازمانها و ورئن يزوهشكرانى كه از نظر برونداد علمى شاخص هستند را نشان خواهد

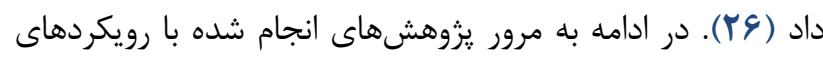
فوق، در حوزه يزوهشى واكسن SARS-COV-2 خواهيم يرداخت. مطالعداى علمسنجى توسط Surulinathi و همكاران در سال

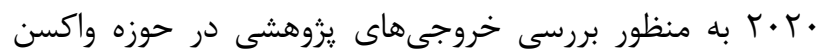

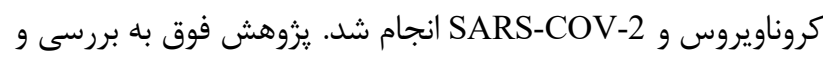

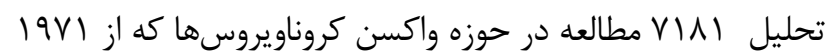

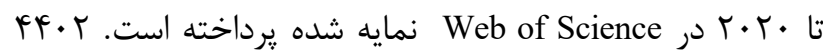

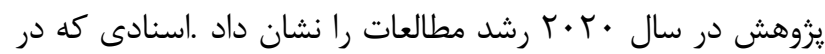

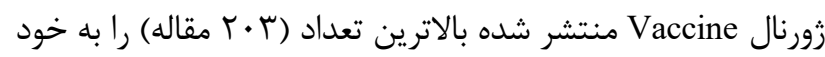

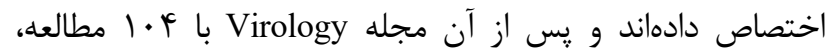
Nature

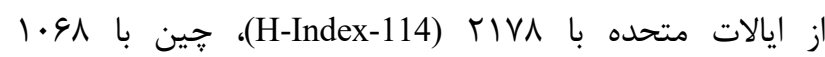
SIf (H-Index-75) و Surulinathi (H-Index-53)

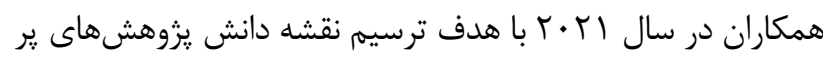

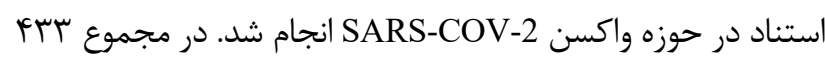
يزوهش در مورد واكسن Covid-19 كه ATDSV استناد دريافت كرده بود، بررسى شد. تعداد متوسط استنادها براى هر يزونش

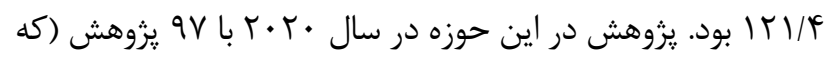

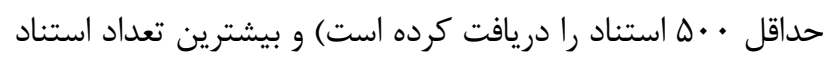

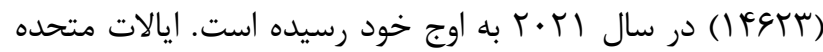

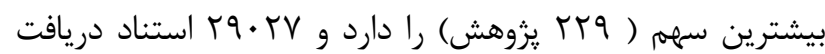

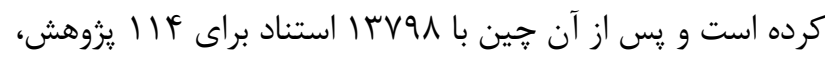

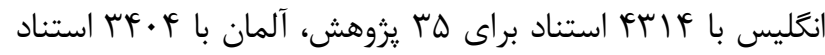

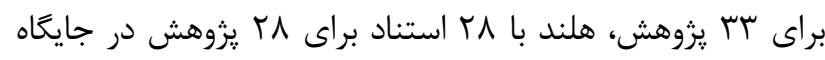

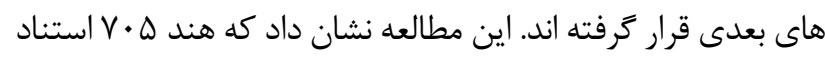

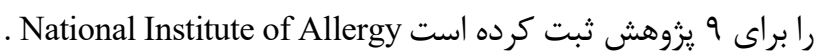
and Infectious Diseases

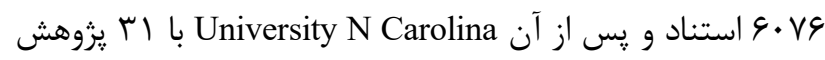

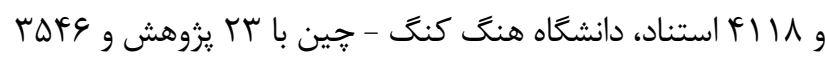

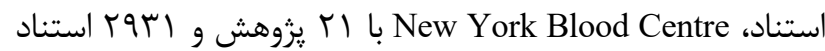
برترين موسسات هستند. نشريه VIROLOGY با DYF 
را تمام يروهشهاى مرتبط با واكسن كوويد 19 در WOS در مرتبط با حوزههاى :زشكى و سلامت در بازه زمانى Categories

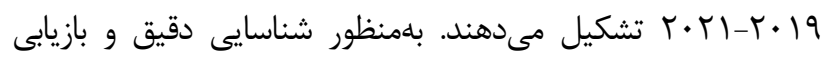

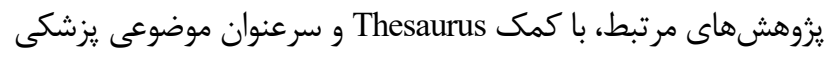

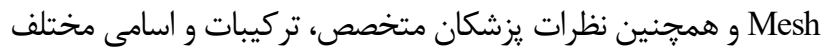

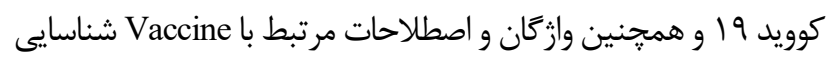

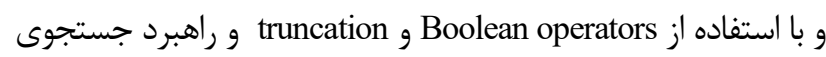
קند مرحلداى زير، مطالعات حوزه يزوهشى مورد نظر در جهان و ايران

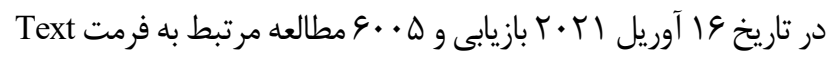

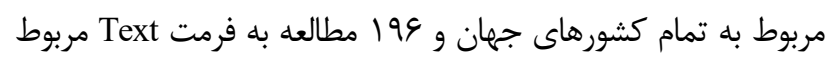

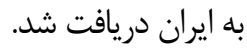

((TS="COVID 19") OR (TS="coronavirus disease 2019")

OR OR (TS="novel coronavirus") OR (TS="2019 ncov") (TS="coronavirus 2019") OR (TS="new coronavirus") OR

$(\mathrm{TS}="$ sars-cov 2") OR (TS="nCoV-19")) AND (TS=Vaccin*)

لازم به ذكر است از آنجايى كه Clarivate Analytics سقف تعداد ركوردهاى دانلودى را .ه ركورد تعيين كرده، بنابراين استخراج دادهها

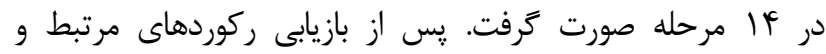

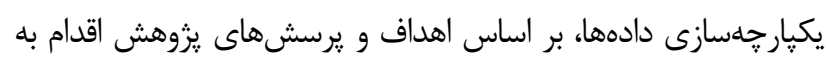

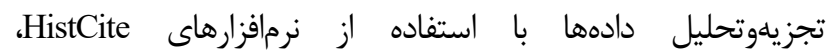
SPSS و UCINET ، Gephi،Bibexecl نرمافزار VOSviewer (نسخه • (، و، () استفاده شده است. به منظور

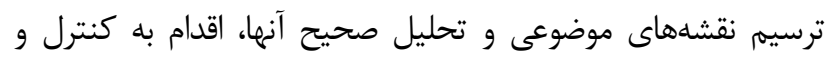
يكدستسازى كليدوازهها از طريق ساخت Thesaurus در نرمافزار كرديد به گَونهاى كه كليدوازمهاى مشابه، يكسان، متشابه و حالتهاى

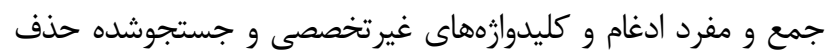

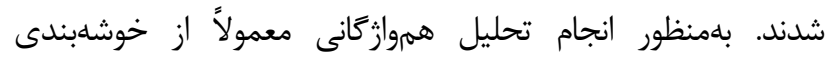

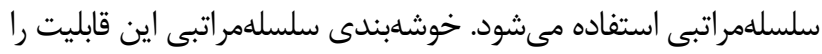

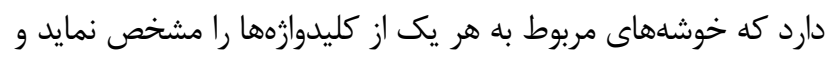
روابط بين آنها را نشان دهد. به همين دليل، با استفاده از نرمافزار اس.بیى.اس.اس خوشهبندى سلسله مراتبى انجام شد. در روش خوشه

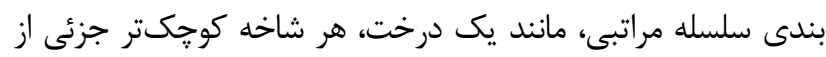

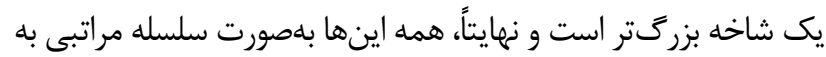
تنه آن درخت وصل مىشوند. بهطور خلاصه بر اساس روش وارد بايد مراحل زير طى گردد:

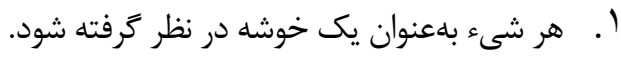

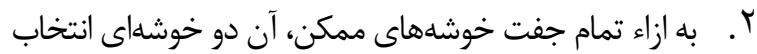

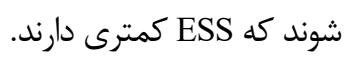

نقشههاى علمى و همكارى به عنوان يكى از مهمترين وجوه مطالعات

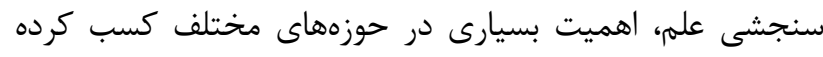

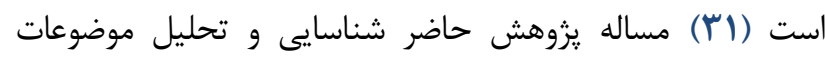

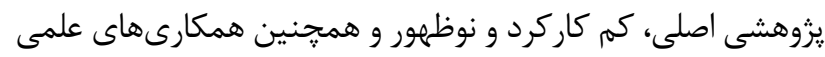
جهان و ايران در مطالعات واكسن SARS-COV-2 براساس فنون

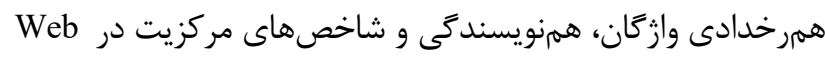
of science بطور خاص وزارت بهداشت، مراكز علمى، يزوهشكران و علاقمندان

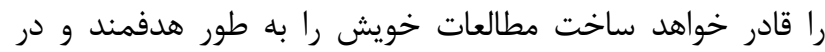

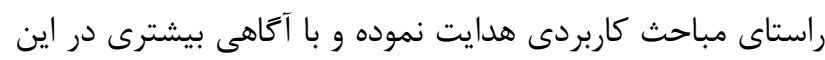
حوزه بيش روند. در واقع، يزوهش حاضر در صدد است ساختار

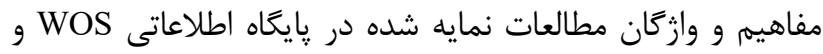

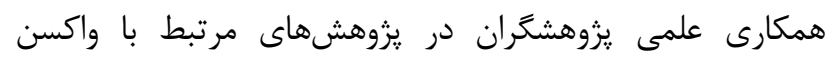

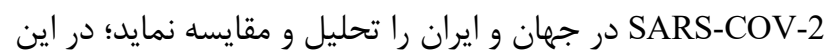
راستا يزوهش حاضر به برسشهاى زير باسخ خواهد داد:

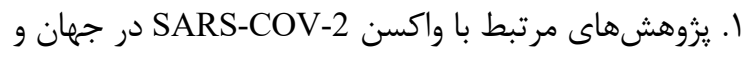
ايران از نظر قالب اثر، زبان، كشورها، مؤسسات و و يزوهشكَران

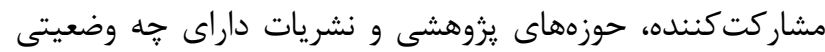

SARS- Tوشهها و موضوعات يزوهشهاى مرتبط با واكسن COV-2

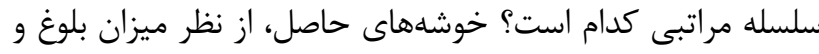
توسعه يافتتى در نمودار راهبردى در جه وضعيتى قرار دارند؟ r. شبكههاى همكارى علمى يزوهشهاى مرتبط با واكسن SARS-COV-2

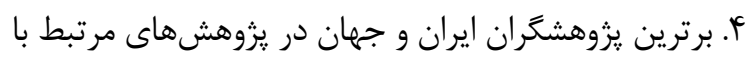
واكسن SARS-COV-2، بر اساس سنجههاى مركزيت شبكه

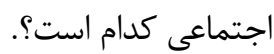

$$
\text { مواد و روشها }
$$

يزوهش حاضر از نوع توصيفى-تحليلى با رويكرد Scientometrics

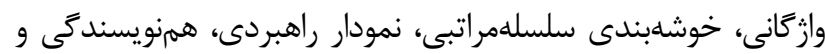
تحليل شبكه اجتماعى انجام شده است. روش تحليل هموازكانى كه در

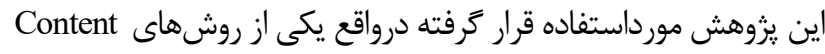
Analysis نشاندهنده جايخاه يك Node (موجوديت) نسبت به گرههاى ديكر در

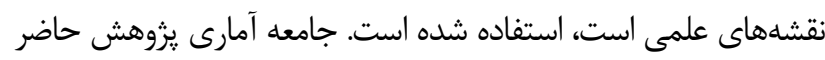


كليدوازه هاى هريك از خوشه هاى بدست آمده از طريق نمودار سلسله

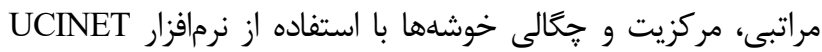

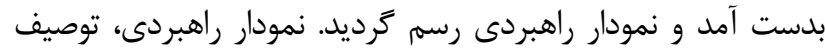
ارتباط درونى و همبستگى بين خوشههاى موضوعى متفاوت است. در

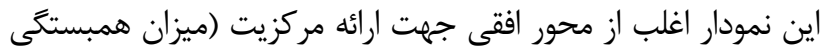
خوشهها) و از محور عمودى جهت ارائه تراكم (ميزان توان ارتباط درونى هر خوشه) استفاده مىشود.

كافته ها

با جستجو در WOS و استفاده از نرمافزار HistCite تعداد

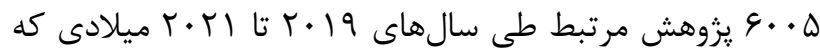

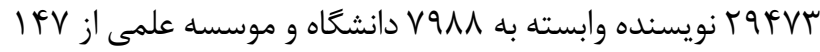
كشور در اين مطالعات مشاركت داشتهاند از طريق پايڤاه مزبور بازيابى شدند. در ادامه وضعيت يروهشهاى اين حوزه از نظر قالب اثر، زبان، كشورها، مؤسسات و يُوهشگران مشاركت كننده، حوزههاى يزوهشى و نشريات در جدول ا آمده است. بهطور متوسط هر اثر مرتبط، ه ه Citation 1. دريافت كرده است. همجنين H index r. دو خوشهاى كه انتخاب شدهاند با هم تركيب شوند. † · تا زمانى كه همه اشياء در يك خوشه قرار نترفتهاند، يا تعداد خوشهها به تعداد موردنظر نرسيده است، مراحل 2 و 3 تكرار

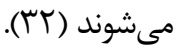

جهت اجرايى كردن و به نتيجه رساندن تحليل همرخدادى وازگًان بايستى ابتدا ملزوماتى ازجمله ماتريس همرخدادى تهيه شود و سيس ماتريس همرخدادى به ماتريس همبستگى تبديل شود. براى تهيه ماتريس، كليدوازههاى داراى فراوانى ب براى يروهش هاى ايران و

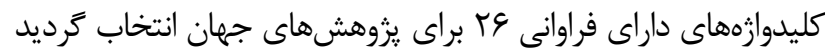

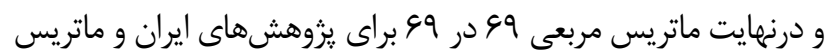
مربعى •V در • V براى يزوهشهاى جهان تشكيل گرديد. سلولهاى مورب ماتريسها صفر در نظر گرفته شد و سيس اين ماتريسهاى معمولى به ماتريس همبستخى تبديل شدند. نهايتاً خوشهبندى مفاهيم بر اساس نرم افزار آمارى SPSS (نسخه צr) ترسيم شده است. در مرحله بعد نمودار راهبردى خوشههاى موضوعى رسم شد؛ براى رسم نمودار راهبردى، يس از تشكيل ماتريسهاى مجزا براى

جدول ا. وضعيت يزوهشهاى مرتبط با واكسن كوويد 19 در جهان

\begin{tabular}{|c|c|c|c|c|c|}
\hline جايحًاه ينجم (تعداد، درصد) & 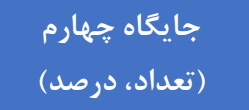 & جايعاه سوم & جايگاه دوم & 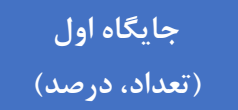 & \\
\hline $\begin{array}{l}\text { Letter } \\
(r / \Delta \cdot r \cdot \Lambda)\end{array}$ & $\begin{array}{l}\text { News Item } \\
(r / \varepsilon ، r \mid Q)\end{array}$ & $\begin{array}{l}\text { Editorial Material } \\
\qquad(|r| V Y I)\end{array}$ & $\begin{array}{l}\text { Review } \\
(r \& / \Gamma ، \backslash \Delta \vee \wedge)\end{array}$ & $\begin{array}{c}\text { Article } \\
(\Delta \cdot \sqrt{\mid} \cdot \cdot 1)\end{array}$ & نوع يثوهش \\
\hline $\begin{array}{c}\text { تركى } \\
(\text { )/ll) }\end{array}$ & 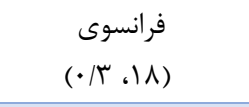 & 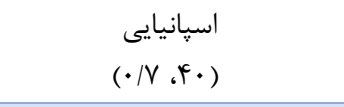 & 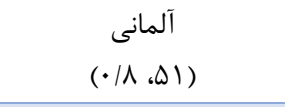 & 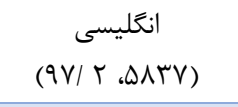 & زبان \\
\hline 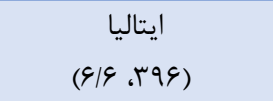 & 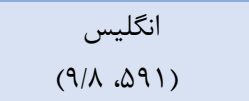 & 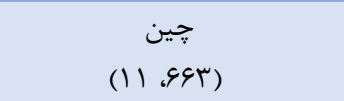 & $\begin{array}{c}\text { هند } \\
(I K / K, V / r \cdot)\end{array}$ & 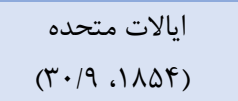 & كشور \\
\hline $\begin{array}{c}\text { Kumar S, } \\
(\cdot|r| r \mid)\end{array}$ & $\begin{array}{l}\text { Tiwari R } \\
(\cdot / \mathbb{F} \text {, r })\end{array}$ & 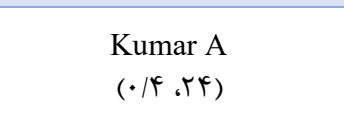 & $\begin{array}{l}\text { Baric RS } \\
(\cdot / \mathcal{F} r \Delta)\end{array}$ & $\begin{array}{c}\text { Dhama K, Mahase } \\
\text { E } \\
(\cdot 19,4 \text { (4) }\end{array}$ & يزوهشگر \\
\hline $\begin{array}{c}\text { London Sch Hyg \& } \\
\text { Trop Med } \\
(1 / 1 . \& 4)\end{array}$ & $\begin{array}{l}\text { Chinese Acad Sci } \\
(1 / 1.49)\end{array}$ & $\begin{array}{l}\text { Univ Washington } \\
\qquad(1 / \mathcal{\complement} ، \Delta \omega)\end{array}$ & $\begin{array}{l}\text { Univ Oxford } \\
(1 / \mathrm{V}, 1 \cdot r)\end{array}$ & $\begin{array}{c}\text { Harvard Med } \\
\text { Sch } \\
(I / \mathrm{V}, \mathrm{I} \cdot \mathrm{f})\end{array}$ & مؤسسه \\
\hline $\begin{array}{c}\text { NIH NATIONAL } \\
\text { INSTITUTE OF } \\
\text { ALLERGY } \\
\text { INFECTIOUS } \\
\text { DISEASES NIAID } \\
(Y / r \mid \mathrm{l} / \uparrow \cdot)\end{array}$ & $\begin{array}{l}\text { EUROPEAN } \\
\text { COMMISSION } \\
(r / \Delta \Lambda|،| \Delta \varphi)\end{array}$ & $\begin{array}{l}\text { NATIONAL NATURAL } \\
\text { SCIENCE } \\
\text { FOUNDATION OF } \\
\text { CHINA NSFC } \\
(r / \& V \Delta, r) \cdot)\end{array}$ & $\begin{array}{c}\text { NATIONAL } \\
\text { INSTITUTES OF } \\
\text { HEALTH NIH USA } \\
(\Lambda / \text { I \& ، ধq })\end{array}$ & 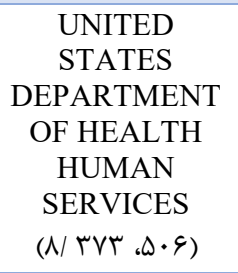 & حامى مالى \\
\hline $\begin{array}{c}\text { FRONTIERS IN } \\
\text { IMMUNOLOGY } \\
(1 / 9.9 \Delta)\end{array}$ & $\begin{array}{l}\text { VACCINE } \\
(1 / 9.9 \varsigma)\end{array}$ & $\begin{array}{l}\text { NATURE } \\
\left(1 / V_{،}(1 \cdot r)\right.\end{array}$ & $\begin{array}{l}\text { VACCINES } \\
(T / r, \text { (T) }\end{array}$ & $\begin{array}{l}\text { BMJ-BRITISH } \\
\text { MEDICAL } \\
\text { JOURNAL } \\
(\Upsilon / \Delta,(\Delta))\end{array}$ & نشريه \\
\hline
\end{tabular}




\begin{tabular}{|c|c|c|c|c|c|}
\hline جايگاه ينجم (تعداد، درصد) & 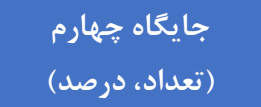 & 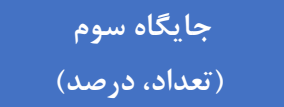 & 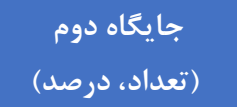 & 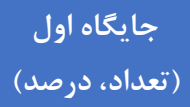 & \\
\hline $\begin{array}{c}\text { BIOCHEMISTRY } \\
\text { MOLECULAR } \\
\text { BIOLOGY } \\
\text {,SCIENCE } \\
\text { TECHNOLOGY } \\
\text { OTHER TOPICS } \\
(\Delta / \Delta \wedge \wedge \text { (১) } 9)\end{array}$ & 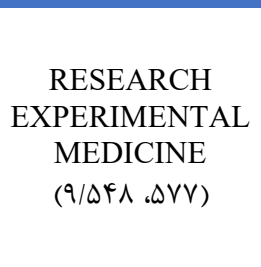 & $\begin{array}{l}\text { PHARMACOLOGY } \\
\text { PHARMACY } \\
\text { (१/q।r. . १९) }\end{array}$ & $\begin{array}{l}\text { IMMUNOLOGY } \\
(\mid r / V \Psi \Delta ، \wedge r \cdot)\end{array}$ & $\begin{array}{l}\text { GENERAL } \\
\text { INTERNAL } \\
\text { MEDICINE } \\
(I \notin / \uparrow \& 4 ، \wedge \vee \uparrow)\end{array}$ & حوزه \\
\hline
\end{tabular}

طريق يايحاه مزبور بازيابى شدند. در ادامه وضعيت يزوهشهاى اين حوزه در ايران از نظر قالب اثر، زبان، كشورها، مؤسسات و وندات

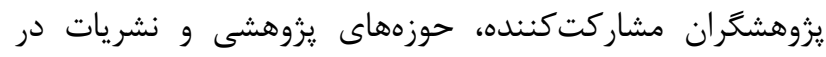

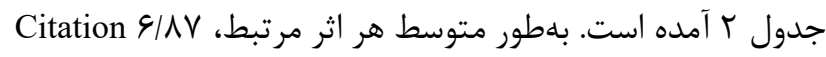

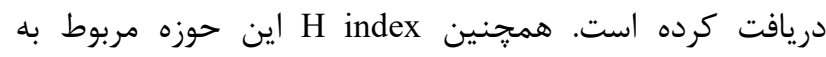
مطالعات ايران در WOS، 19 است.
نكته قابل توجه جايگاه ايران در ميان كشورهاى

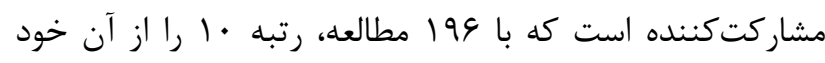
كرده است. يس از محدودسازى نتايج بازيابى شده به كشور ايران،

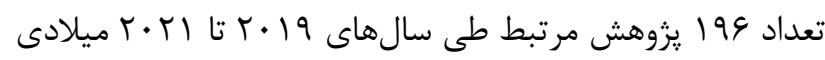

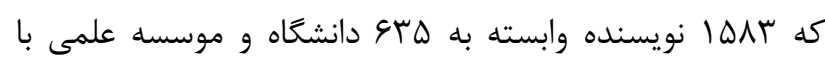
همكارى VG كشور همكار در اين مطالعات مشاركت داشتهاند از

\begin{tabular}{|c|c|c|c|c|c|}
\hline جايگًاه بنجمم (تعداد، درصد) & جايگاه جهارم & جايگًاه سوم (تعداد، & جايكًاه دوم (تعداد، درصد) & جايكاه اول (تعداد، & \\
\hline - & $\begin{array}{l}\text { Letter } \\
(1 / \Delta, r)\end{array}$ & $\begin{array}{l}\text { Editorial Material } \\
\qquad(r / \&, V)\end{array}$ & $\begin{array}{l}\text { Article } \\
(\Psi \& / V \text { VT) }\end{array}$ & $\begin{array}{l}\text { Review } \\
\left(\Delta \Lambda / r ، \| /{ }^{\prime}\right)\end{array}$ & يزوهش نوع \\
\hline \multicolumn{3}{|c|}{$\begin{array}{l}\text { Akbari A, Hemmat N, Iravani S, Khodavirdipour A, } \\
\text { Lotfi M, Negahdaripour M, Nosrati H, } \\
\text { Pormohammad A, Rahimi F, Ranjbar R, } \\
\text { Sadeghi S, Sahebkar A, Soltani S, Soufi GJ, Zandi M } \\
(1 / \Delta, r)\end{array}$} & $\begin{array}{l}\text { Abadi ATB } \\
(\uparrow, r)\end{array}$ & $\begin{array}{l}\text { Rezaei N } \\
(\mathcal{f} /\rfloor ، \wedge)\end{array}$ & يثوهشعر \\
\hline 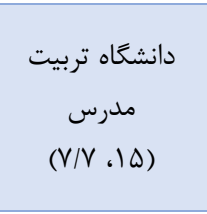 & 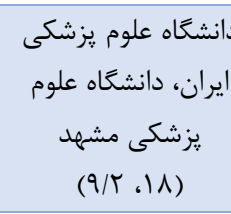 & 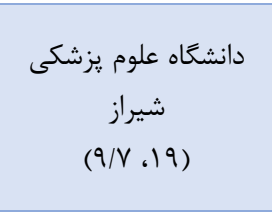 & 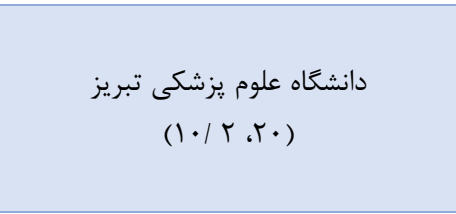 & 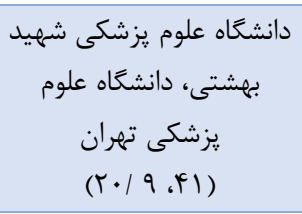 & مؤسسه \\
\hline \multicolumn{3}{|c|}{$\begin{array}{l}\text { HAMADAN UNIVERSITY OF MEDICAL SCIENCES HAMADAN } \\
\text { IRAN, NATIONAL INSTITUTE FOR HEALTH RESEARCH NIHR, } \\
\text { NATIONAL INSTITUTES OF HEALTH NIH USA, } \\
\text { RESEARCH COUNCIL OF SHIRAZ UNIVERSITY OF MEDICAL } \\
\text { SCIENCES SHIRAZ IRAN, } \\
\text { TURKIYE BILIMSEL VE TEKNOLOJIK ARASTIRMA KURUMU } \\
\text { TUBITAK, } \\
\text { IRAN S NATIONAL ELITES FOUNDATION } \\
(1 / v, r)\end{array}$} & $\begin{array}{c}\text { CGIAR, NATIONAL INSTITUTE OF } \\
\text { GENETIC ENGINEERING AND } \\
\text { BIOTECHNOLOGY NIGEB OF THE } \\
\text { ISLAMIC REPUBLIC OF IRAN, } \\
\text { PASTEUR INSTITUTE OF IRAN, } \\
\text { SHIRAZ UNIVERSITY OF } \\
\text { MEDICAL SCIENCES } \\
(1 / \Delta r / . r)\end{array}$ & 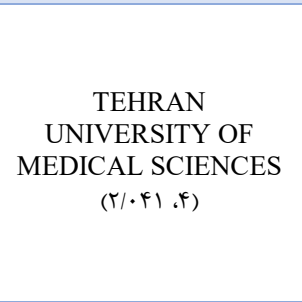 & 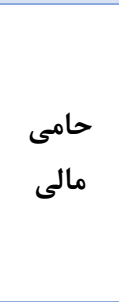 \\
\hline \multicolumn{3}{|c|}{$\begin{array}{c}\text { ARCHIVES OF BONE AND JOINT SURGERY-ABJS, } \\
\text { EXPERT REVIEW OF ANTI-INFECTIVE THERAPY, } \\
\text { JOURNAL OF CELLULAR PHYSIOLOGY, } \\
\text { VACCINE, } \\
\text { EUROPEAN JOURNAL OF PHARMACOLOGY, } \\
\text { ARCHIVES OF CLINICAL INFECTIOUS DISEASES } \\
(\mathrm{l} / \mathrm{r} \cdot \mathrm{r})\end{array}$} & $\begin{array}{l}\text { ARCHIVES OF MEDICAL RESEARCH, } \\
\text { BIOLOGICAL PROCEDURES ONLINE, } \\
\text { INTERNATIONAL } \\
\text { IMMUNOPHARMACOLOGY, } \\
\text { BIOMEDICINE \& PHARMACOTHERAPY } \\
\text { PLOS ONE, } \\
\text { REVIEWS IN MEDICAL VIROLOGY } \\
(\uparrow, \uparrow)\end{array}$ & $\begin{array}{l}\text { JOURNAL OF } \\
\text { BIOMOLECULAR } \\
\text { STRUCTURE \& } \\
\text { DYNAMICS } \\
(\uparrow / 1 ، \wedge)\end{array}$ & 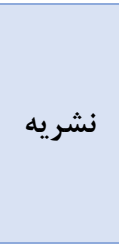 \\
\hline $\begin{array}{l}\text { INFECTIOUS } \\
\text { DISEASES } \\
(V / \backslash \uparrow \Psi, \| \uparrow)\end{array}$ & $\begin{array}{l}\text { IMMUNOLOGY } \\
\text { (9/994،।9) }\end{array}$ & $\begin{array}{l}\text { RESEARCH } \\
\text { EXPERIMENTAL } \\
\text { MEDICINE } \\
(1) / \text { rTr, rT })\end{array}$ & 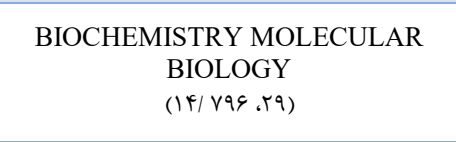 & $\begin{array}{l}\text { PHARMACOLOGY } \\
\text { PHARMACY } \\
\text { (। १/ ^৭^، ৫৭) }\end{array}$ & يزوهشى حوزه \\
\hline
\end{tabular}


Cryo-EM structure of the 2019-nCoV spike in the » Goldsmith, JA, " " از نويسندكان "prefusion conformation ،Abiona, O ،Hsieh, CL ،Corbett, KS; Wang, NS, Wrapp, D 《McLellan, JS ،Graham, BS

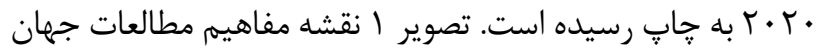
در حوزه يزوهشى واكسن كوويد را نشان مي دهد. لازم بهذكر است بزر و رنك آنها نشاندهنده خوشه مفاهيم است. ضمن اينكه در اين نقشه دورى و نزديكى كليدوازهها نشان مىدهد كه مفاهيم جه مقدار به همديخر مرتبط هستند.
در كام بعدى يزوهش بلمنظور ترسيم و تحليل خوشهها و موضوعات مربوط به يزوهشهاى مرتبط با واكسن كوويد 19 در

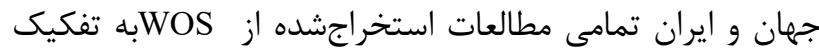
مطالعات جهان و ايران وارد نرمافزار VOSviewer شد. در ادامه نقشه دانش :زثوهشهاى جهان و ايران و كليدوازههاى برتر آنها بر اساس سنجههاى مركزيت آمده است.

الف. مطالعات جهان به دنبال تحليل هموازَّانى مطالعات اين حوزه، V خوشه از وازگًان و مفاهيم شناسايى شد. يراستنادترين يزوهش با عنوان

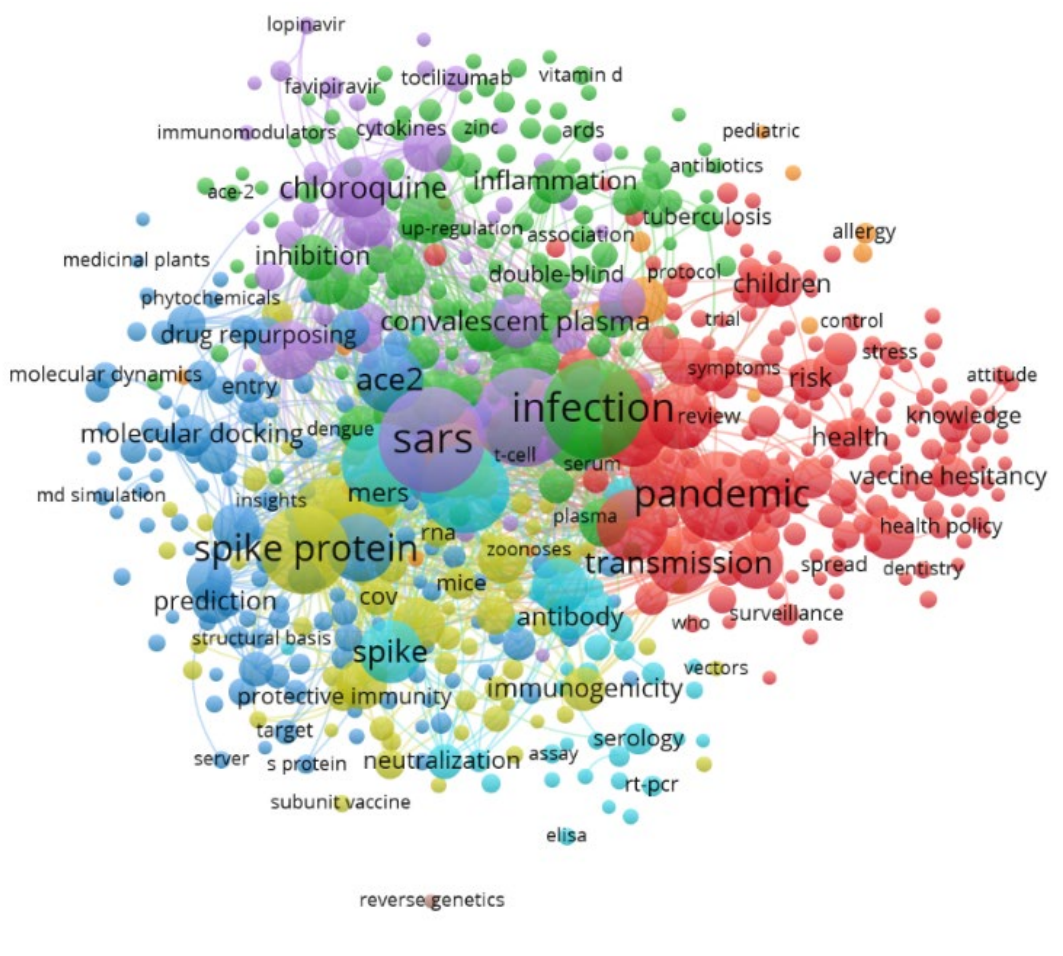

تصوير ا. مفاهيم و خوشههاى موضوعى مطالعات جهان در حوزه واكسن كوويد 19

تقسيم شدهاند. در اين نمودار ارتفاع هر يك از خوشهها بيانكر آن است كه دو خوشه موردنظر در جه نقطههايى با يكديگر تركيب شدهاند؛ همجنين خطوط عمودى قرمز رنگ خط شاخص تفسير است كه با نظر متخصص موضوعى ترسيهم مى
با استفاده از نرمافزار SPSS و فراخوانى ماتريسهاى همرخدادى در اين نرمافزار، به روش Ward اقدام به خوشهبندى سلسلهمراتبى گرديد و نمودار دندروگرام (خوشهبندى سلسله مراتبى) موضوعات ترسيم شد. خوشابندى سلسله مراتبى يثوهشهاى مرتبط با واكسن كوويد 19 در تصوير ه نمايش داده شده است. بهمنظور وضوح بيشتر تصاوير خوشهها به جند بخش 


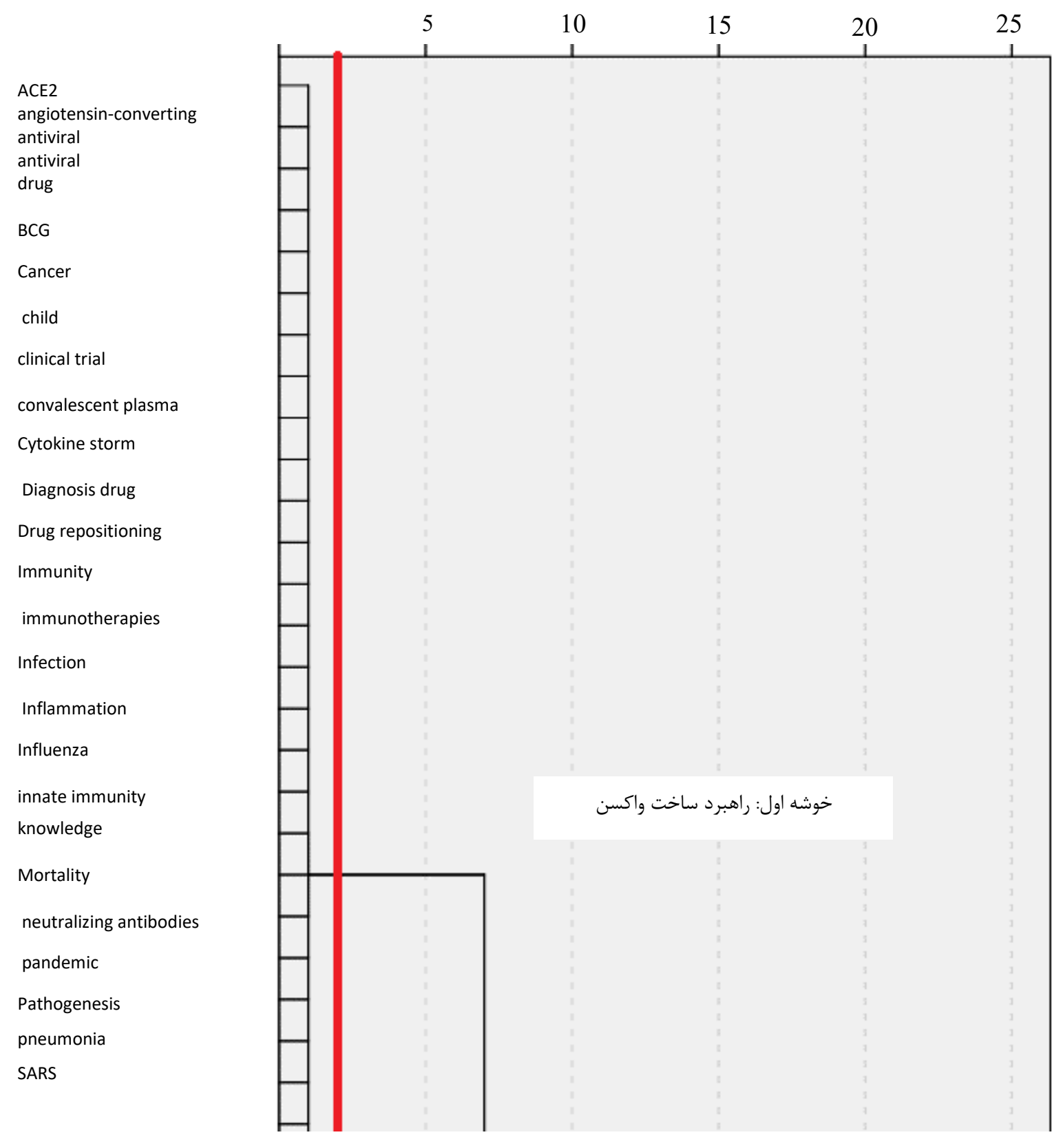




\section{Serology}

social distance

spike (S) protein

Spikeglycoprotein

T cell

Transmission

Treatment

vaccination

vaccine

Vaccin development

adjuvant Corona

Coronavirus infection

COVID-19 vaccine epidemic

Epitope Hydroxychloroguine

Immunization

immunoinformatic

Immunology

Infectious disease

Molecular docking

Mutation

Outbreak prevention

Public health

receptor binding

domain

Remdesevir

Safety

Therapeutics

vaccine hesistancy

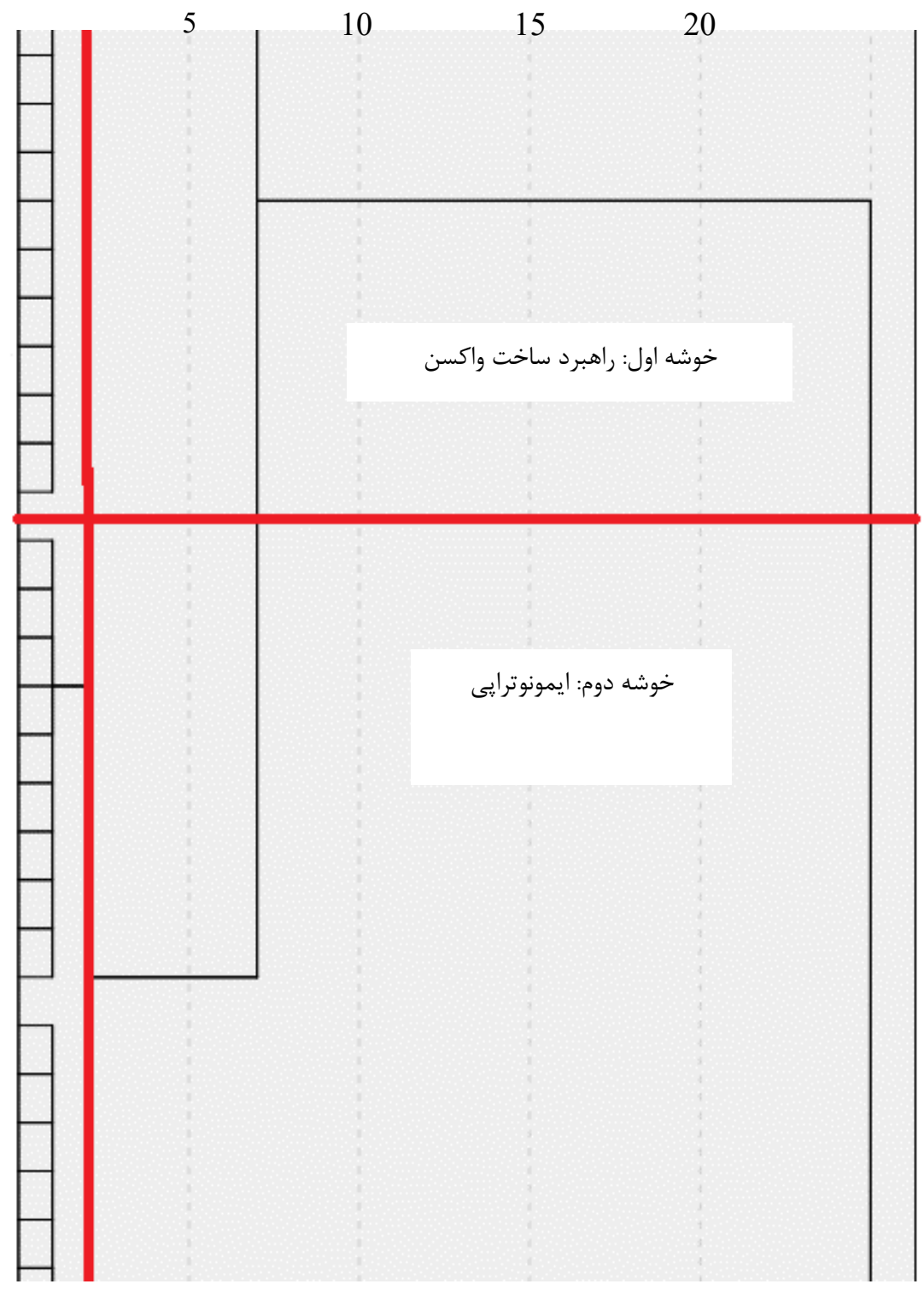


5

receptor binding
domain
Remdesevir
Safety
Therapeutics
vaccine hesistancy
chloroquine
COVID-19 pandemic
infectious diseases
MERS
Molecular dynamics
trained immunity
virology

10

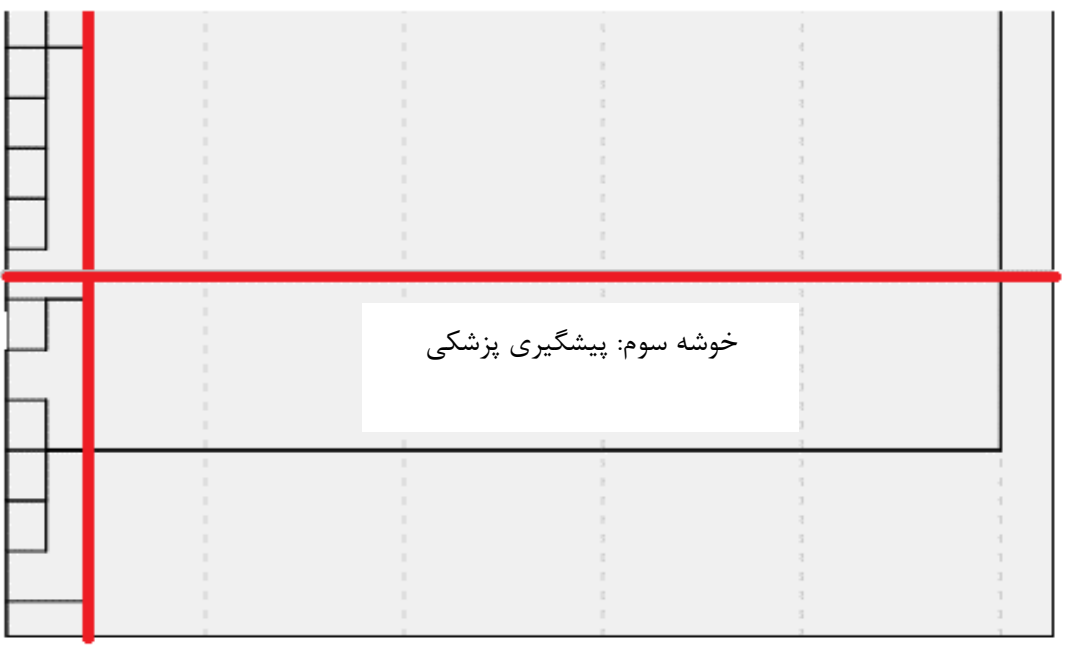

تصوير r. خوشهبندى سلسله مراتبى يزوهشهاى جهان مرتبط با واكسن كوويد 19

\section{خوشه سوم: بيشگيرى بزشكى.}

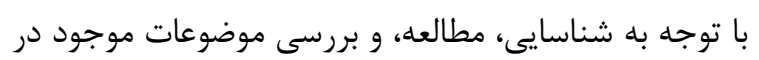

خوشه ب نظير MERS virology ، trained immunity chloroquine 19 pandemic

$$
\text { مناسب به نظر مىرسد. }
$$

يس از تشكيل ماتريس براى هر كدام از خوشهها و فراخوانى نمانى

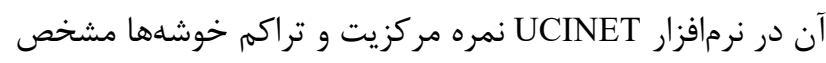

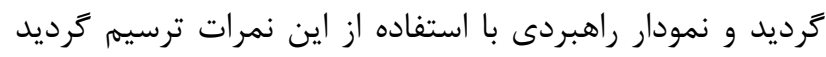

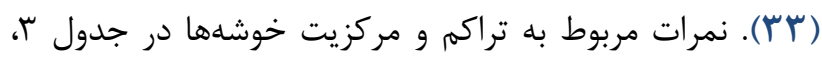

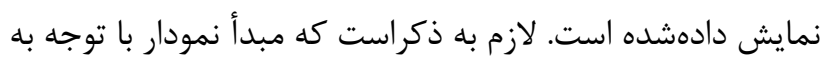

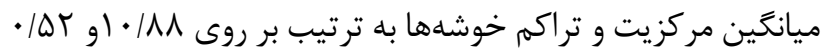

$$
\text { تنظيم كرديد. }
$$

همانطور كه در تصوير r مشاهده مىشود كليدوازههاى

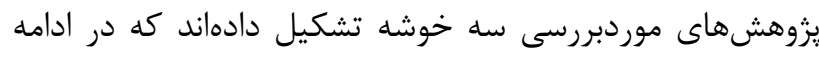
خوشههاى مذكور بررسى مى شوند.

\section{خوشه اول: راهبرد ساخت واكسن.}

نتايج مربوط به تحليل هم وازكانى نشان داد كه خوش خوشه بزركترين خوشه تشكيل شده بوده و كليدوازههاى ACE2، ،Infection ،Immune response ،Cancer ،BCG ،Antibodies convalescent plasma ،clinical trial نخست نقش داشتهاند.

\section{خوشه دوم: ايمونوترايى.}

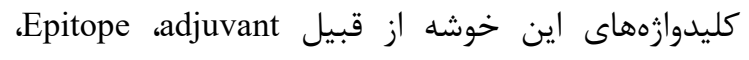
vaccine ،safety ،Remdesevir prevention ،Immunology Immunization ،hesistancy خوشه را ايمونوترايى نام كذارى نمود.

\begin{tabular}{|c|c|c|c|}
\hline مر كزيت & 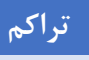 & عنوان خوشه & شماره خوشه \\
\hline Tr/FV & $\cdot / \Delta \mathrm{V}$ & خوشه ا: راهبرد ساخت واكسن & 1 \\
\hline N/Fr & . $/ 4 T$ & خوشه ז: ايمونوترابى & $r$ \\
\hline I/Va & $\cdot \mid \Delta \Lambda$ & خوشه "ا: يِيشَيرى يزشكى & $r$ \\
\hline
\end{tabular}

جدول r. تراكم و مركزيت خوشههاى حاصل از تحليل هموازَّانى يُوهشهاى جهان

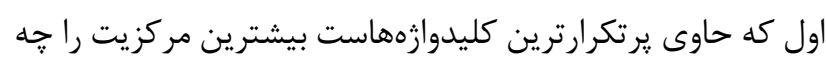

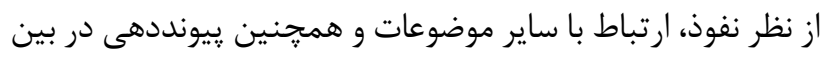

خوشه اول خوشه راهبرد ساخت واكسن با مقدار

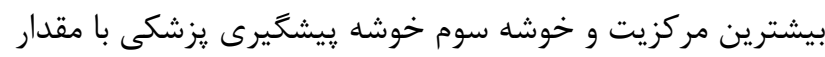

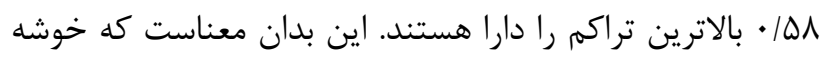


يك، در ناحيه اول و خوشه سه در ناحيه دوم قرار گرفتهاند. لازم به توضيح است خوشههايى كه در ناحيه دوم قرار دارند خوشههاى

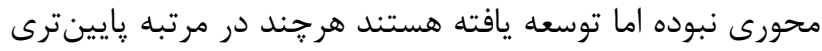

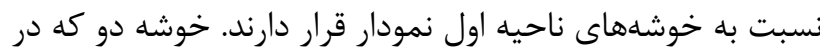

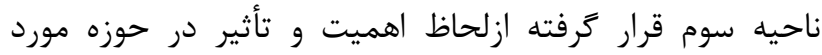
يزوهش، در يايينترين مرتبه نسبت به خوشه نهاى ديكر قرار دار دارد.

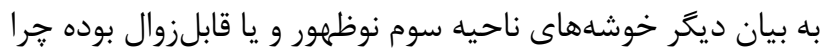
كه به دليل داشتن مركزيت و تراكم يايين، از موضوعات حاشيهائ سوائ بوده و توجه اندكى را به خود جلب كردهاند.

\section{ب. مطالعات ايران}

به دنبال تحليل هموازَّانى مطالعات ايران در حوزه يزوهشى مطان واكسن كوويد 9 1، V خوشه از وازگًان و مفاهيم شناسايى شد. COVID-19, an emerging " يراستنادترين يزوهش با عنوان coronavirus infection: advances and prospects in and developing vaccines, immunotherapeutics, designing Sharun, K; Dhama, K; 》 از نويسندكان "and therapeutics Malik, YS; Singh, KP; Chaicumpa, Tiwari, R ; Dadar, M HUMAN VACCINES \& " در "W IIMMUNOTHERAPEUTICS است. تصوير ؟ نيز نقشه مفاهيم مطالعات ايران در حوزه يزوهشى دال واكسن كوويد را نشان مىدهد.
ساير كليدوازهها داراست. در نمودار راهبردى محور افقى نشاندهنده مركزيت (ميزان همبستكى خوشهها) و محور عمودى نشاندهنده تراكم (ميزان توان ارتباط درونى هر خوشه) است.

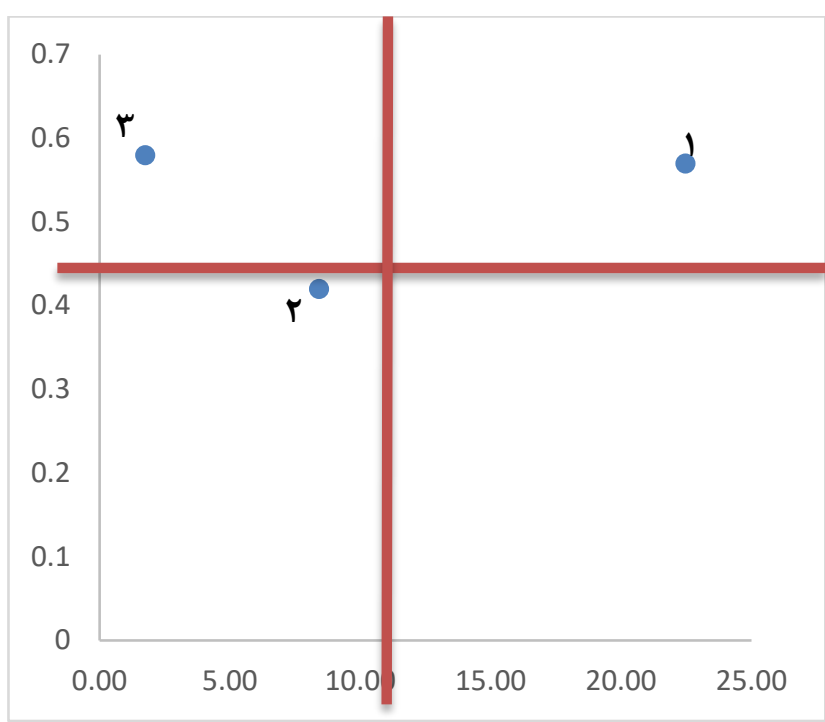

تصوير س. نمودار راهبردى حوزه يزوهش هاى جهان مرتبط با واكسن كوويد 19 با توجه به تنوع موضوعى در اين حوزه و نمودار راهبردى ترسيم شده (تصوير ؟َ)، خوشهها در سه منطقه اول، دوم و سوم حضور دارند. همانطور كه نمودار راهبردى نشان مى دهد، خوشه لنه

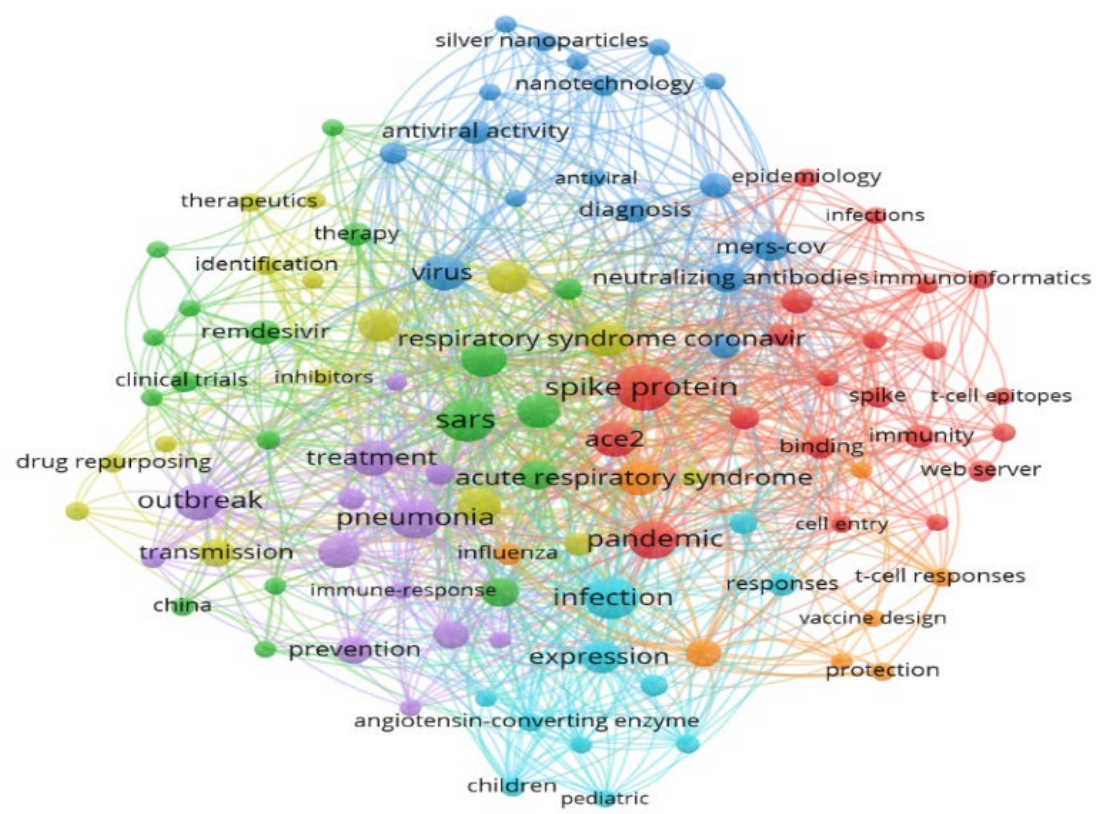

تصوير f. مفاهيم و خوشههاى موضوعى مطالعات ايران در حوزه واكسن كوويد 19 


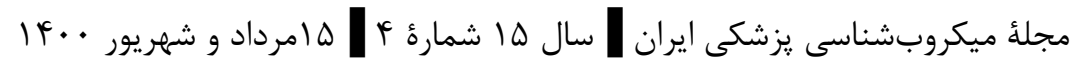

clinical trial

drug

Immunity

Influenza

Therapeutics

Treatment

Diagnosis

Pathogenesis

Vaccine

virus

Antiviral

Cancer

convalescent

plasma

MERS

Outbreak

Pandemic

Prevention

SARS

vaccination

Adjuvant

angiotensin-

converting

enzyme

Antibodies

antiviral drug

BCG

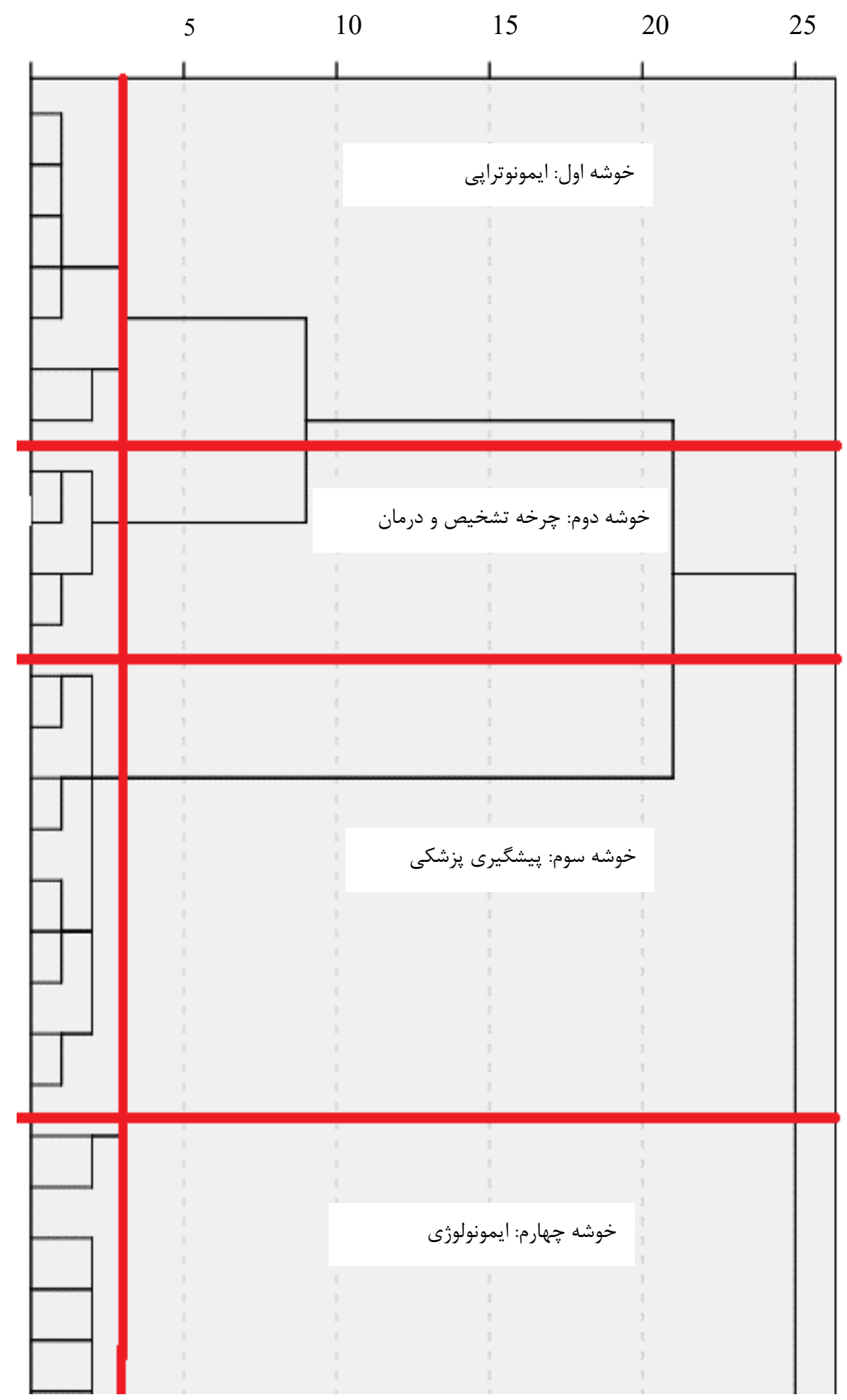




\section{Child \\ Chloroquine \\ Corona}

Coronavirus infection

COVID-19 pandemic

COVID-19 vaccine

Cytokine storm

Drug repositioning

Epidemic

Epidemiology

Epitope

Hydroxychloroguine

Immune response

Immunization

Immunoinformatic

Immunology

Immunotherapies

Infection

infectious disease

inflammation

innate immunity

Knowledge

Molecular docking

Molecular dynamics

Mortality

Mutation

Neutralizing antibodies
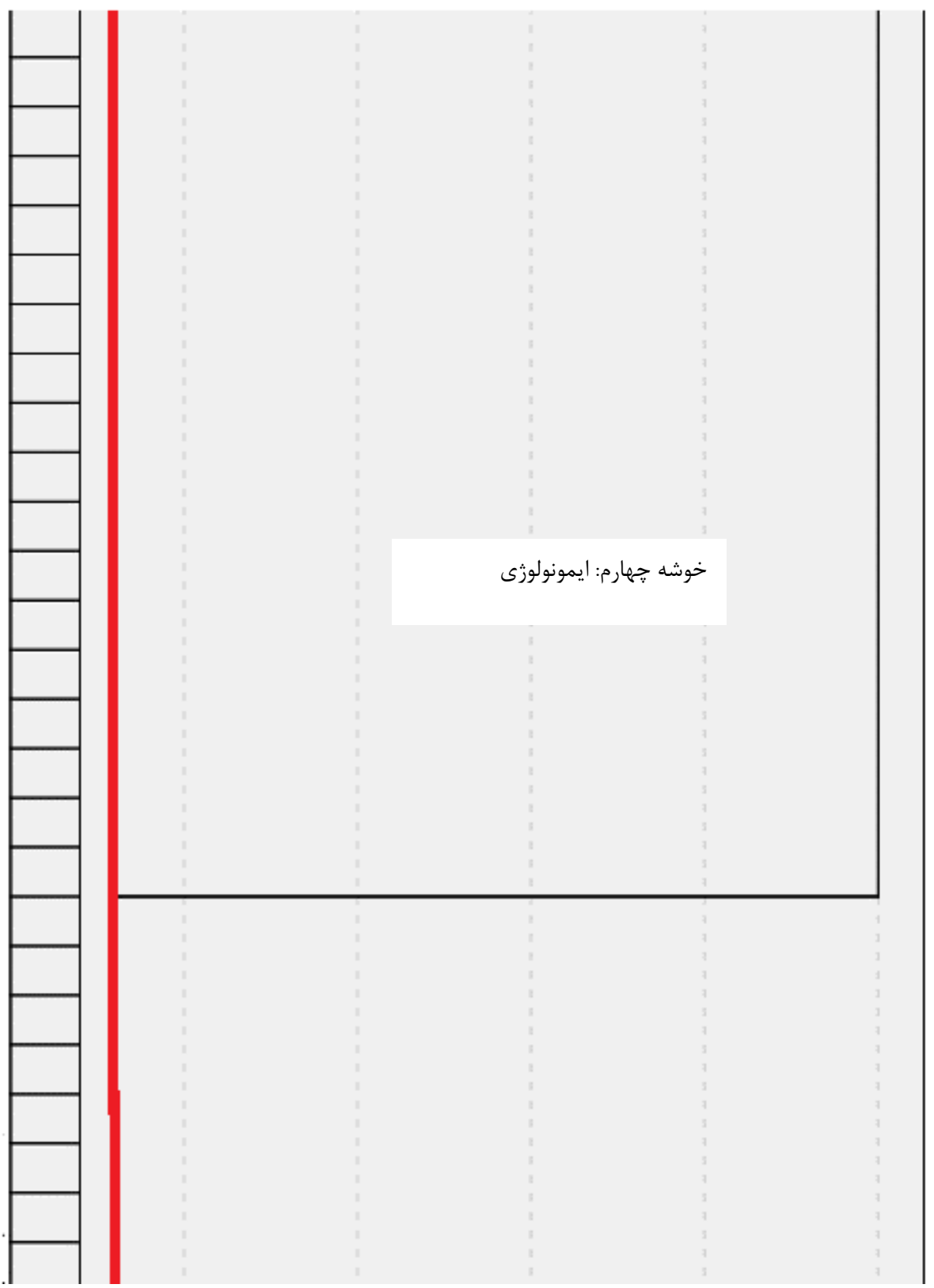


Mutation
Neutralizing antibodies
pneumonia
Public health
receptor binding domain
Remdesevir
Safety
Serology
social distance
spike (S) protein
Spike glycoprotein
T cell
trained immunity
Vaccine
vaccine development
vaccine hesistancy

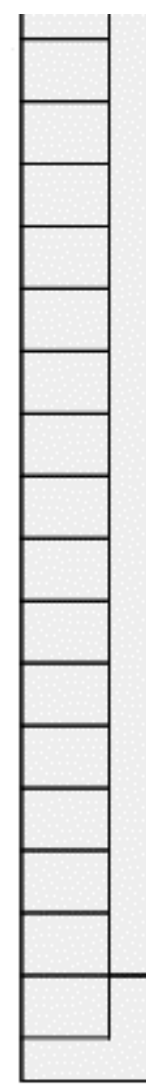

تصوير ه. خوشهبندى سلسله مراتبى يثوهشهاى ايران مرتبط با واكسن كوويد 19

،SARS prevention pandemic ،Outbreak ،MERS vaccination

\section{خوشه جههارم: ايمونولوزى}

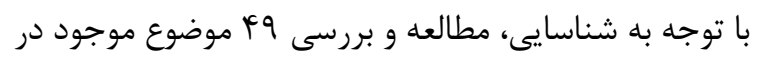

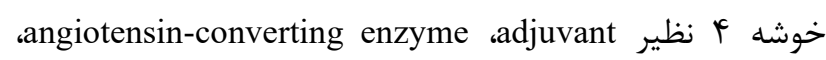
Cytokine ،chloroquine ،BCG antiviral drug ،Antibodies Immunization shydroxychloroguine storm ن immunotherapies Immunology ،immunoinformatic بزركترين خوشه نيز به حساب مى آيد انتخاب نام ايمونولوزى

$$
\text { مناسب به نظر مىرسد. }
$$

نمرات مربوط به تراكم و مركزيت خوشهها در جدول سا،

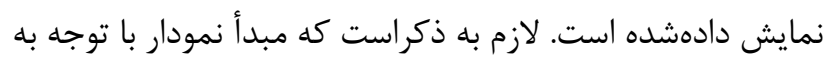

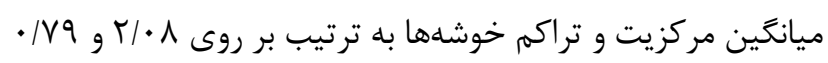

$$
\text { تنظيم كرديد. }
$$

در مرحله بعدى، نمودار دندروكرام (خوشهبندى سلسله مراتبى)

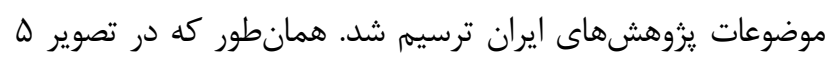

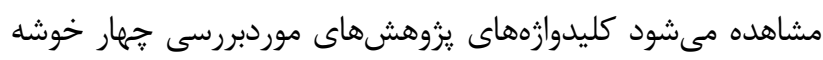

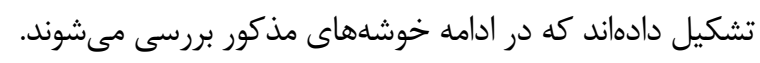

$$
\text { خوشه اول: ايمونوتر ايى }
$$

نتايج مربوط به تحليل هم وازَّانى نشان داد كه در

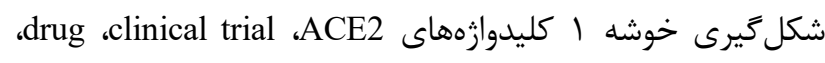
Treatment ،Therapeutics ،Influenza ،Immunity

\section{خوشه دوم: جرخه تشخيص و درمان}

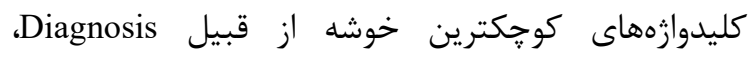
خو و virus vaccine ، Pathogenesis خوشه را جرخه تشخيص و درمان نام كذارى نمود.

\section{خوشه سوم: ييشگيرى يزشكى}

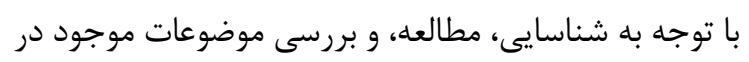

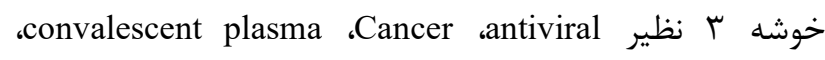


جدول F. تراكم و مركزيت خوشههاى حاصل از تحليل هموازَانى يُوهشهاى ايران

\begin{tabular}{|c|c|c|c|}
\hline مركزيت & 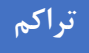 & عنوان خوشه & شماره خوشه \\
\hline $1 / \pi r$ & $\cdot 199$ & خوشه |: ايمونوترايى & 1 \\
\hline$r$ & 1 & خوشه ז: קرخه تشخيص و درمان & $r$ \\
\hline r & $\cdot / \Delta$ & خوشه ऍ!: بيشكيرى يزشكى & $r$ \\
\hline 1 & 1 & خوشه F: ايمونولوزى & F \\
\hline
\end{tabular}

همجنين يِونددهى در بين ساير كليدوازهها داراست. در نمودار

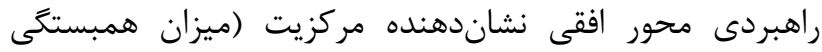
خوشهها) و محور عمودى نشاندهنده تراكم (ميزان توان ارتباط

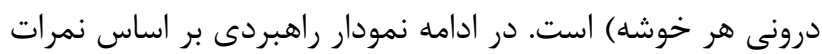
فوق ترسيم شده است.
خوشه سوم خوشه بيشكَيرى يزشكى با مقدار ع ب بيشترين

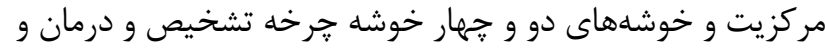

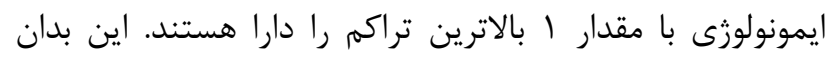
معناست كه خوشه سوم كه حاوى يرتكرارترين كليدوازههاست

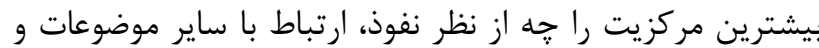

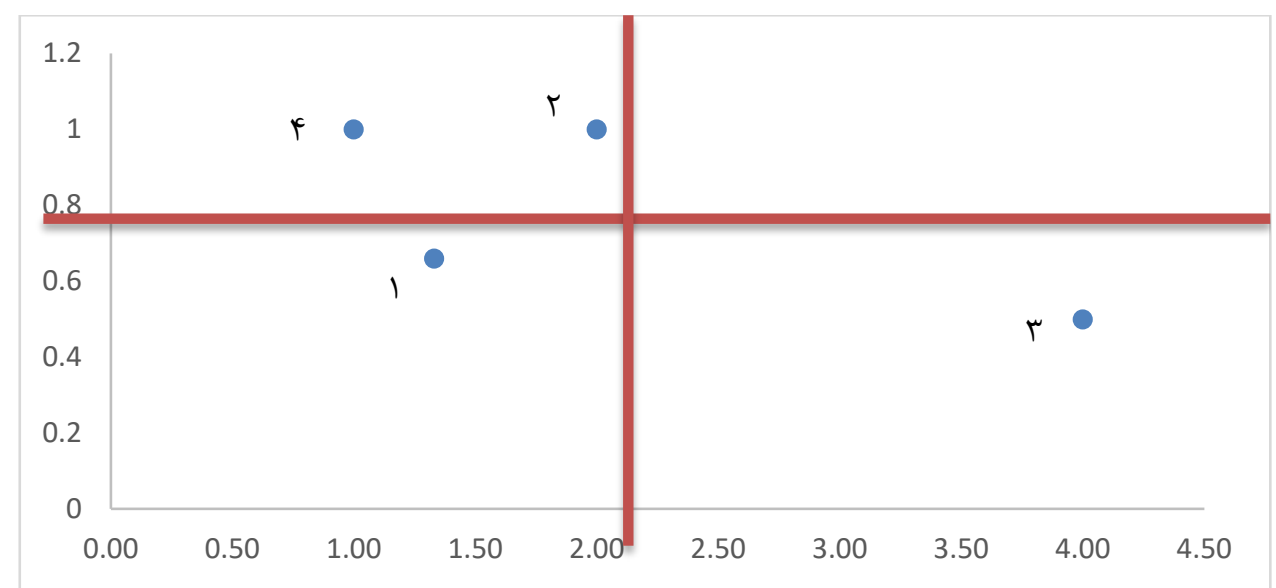

تصوير 9. نمودار راهبردى حوزه يزوهشهاى ايران مرتبط با واكسن كوويد 19

در كام بعدى يزوهش، به منظور ترسيم نقشههاى همكارى

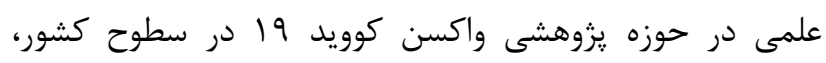

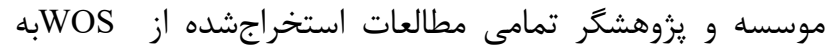

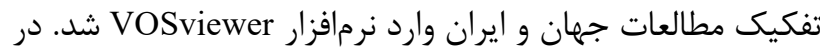

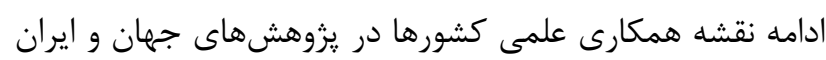

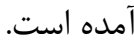

\section{الف. مطالعات جهان}

به دنبال تحليل همنويسندكى مطالعات اين حوزه در جهان ان مهان در سطح همكارى كشورها، ه خوشه از كشورها شناسايى شد

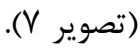

بر اساس تصوير צ، خوشهها در سه منطقه دوم، سوم و جهارم حضور دارند؛ خوشههاى دو و جهار در ناحيه دوم قرار گرفتهاند. خوشههاى ناحيه دوم خوشههاى محورى نبوده اما توسعه يافته هستند هرجند در مرتبه يايينترى نسبت به خوشههاى ناحيه اول

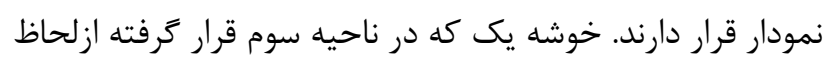
اهميت و تأثير در حوزه مورد ڤيزوهش، در يايينترين مرتبه نسبت به خوشههاى ديخر قرار دارد. به بيان ديخر خوشههاى ناحيه سوم نوظهور و يا قابلزوال بوده جرا كه به دليل داشتن مركزيت و تراكم يايين، از موضوعات حاشيهاى بوده و توجه اندكى را به خود جلب كردهاند. خوشه سوم در ناحيه جهارم نمودار راهبردى قرار گرفته است؛ خوشههايى كه در ناحيه جهارم قرار مى گيرند خوشههاى محورى بوده اما هنوز توسعه نيافتهاند؛ به عبارت ديخر اين خوشه هنوز به بلوغ نرسيده است. 


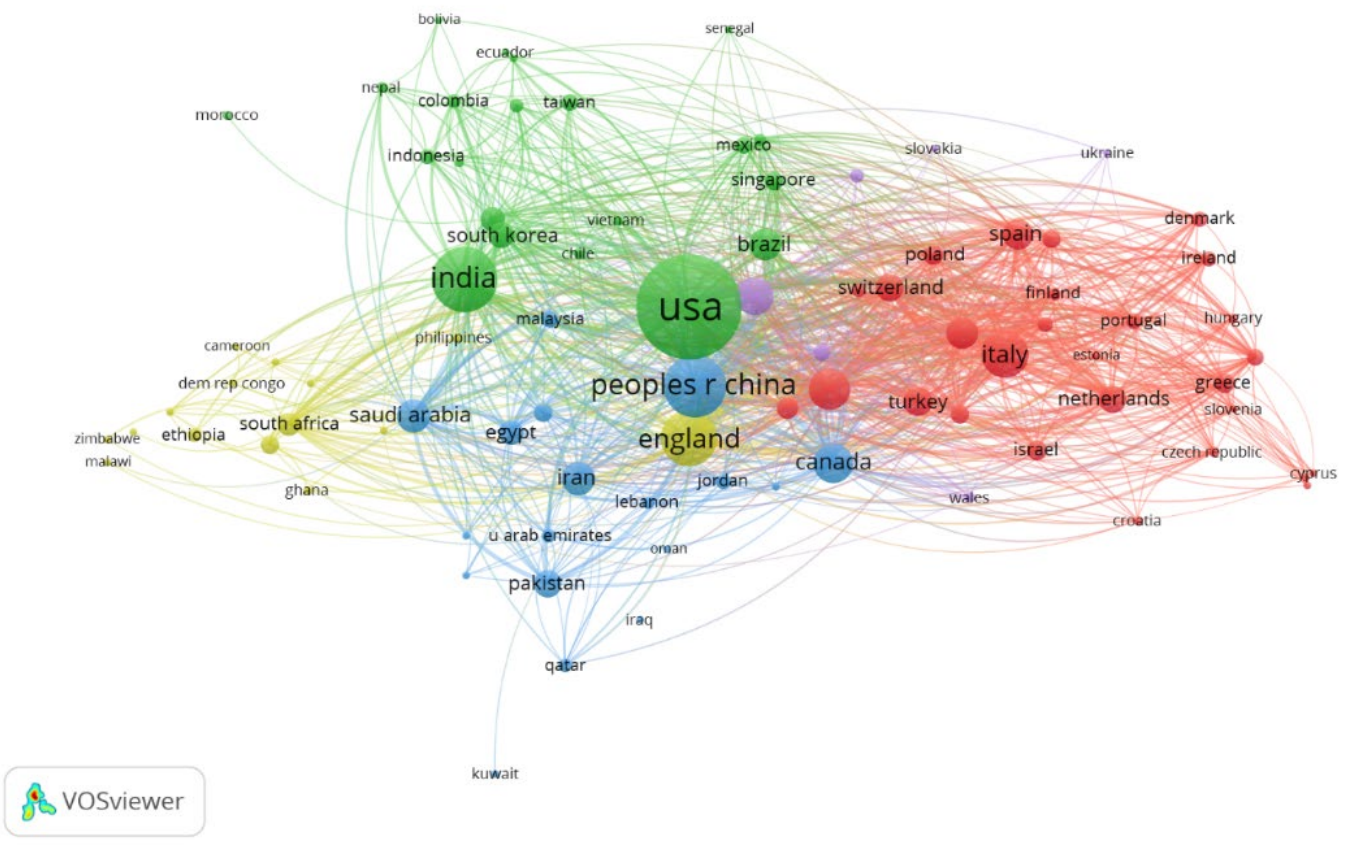

تصوير V. نقشه همكارى علمى كشورها در مطالعات جهان در حوزه واكسن كوويد 19

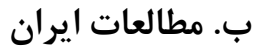

در تحليل همنويسندگى مطالعات اين حوزه در ايران در

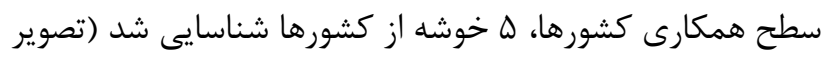

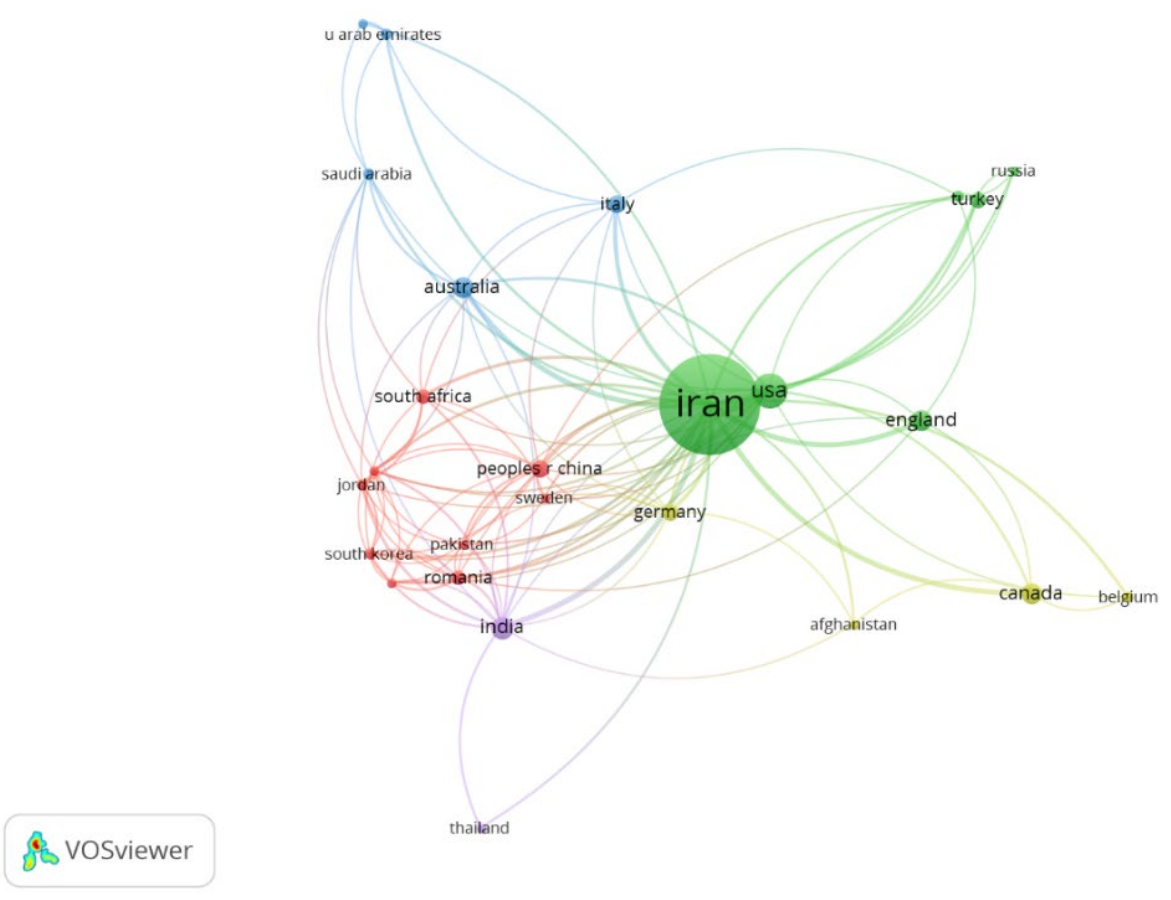

تصوير 1. نقشه همكارى علمى كشورها در مطالعات ايران در حوزه واكسن كوويد 19 
الف. مطالعات جهان

به دنبال تحليل همنويسندكى مطالعات اين حوزه در جهان در سطح همكارى سازمانها، IV خوشه شامل مراكز و و موسئل

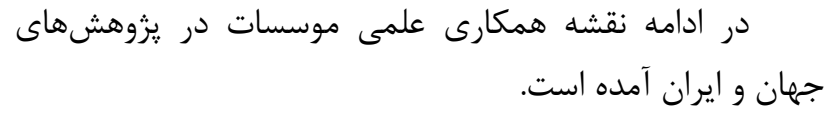

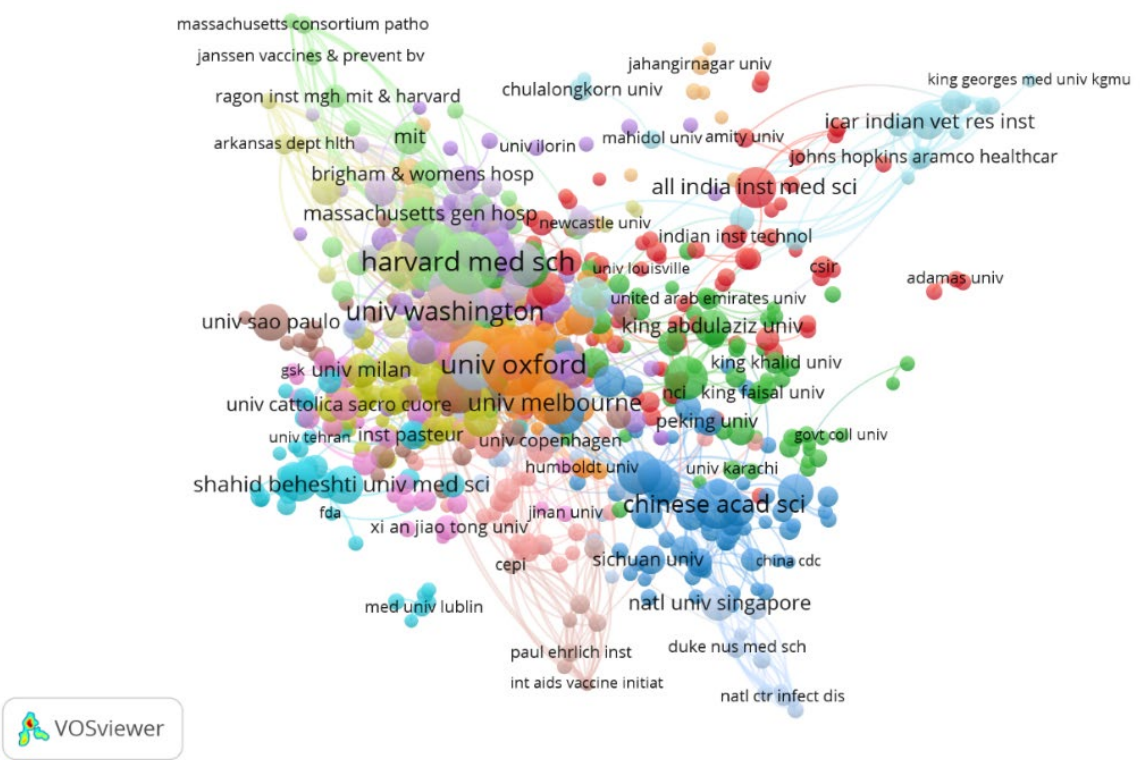

\& vosviewer

علمى شناسايى شد (تصوير 9).

تصوير 9. نقشه همكارى علمى سازمانها در مطالعات جهان در حوزه واكسن كوويد 19

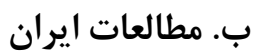

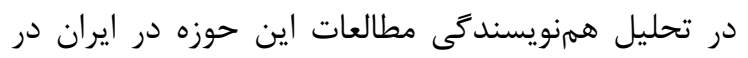

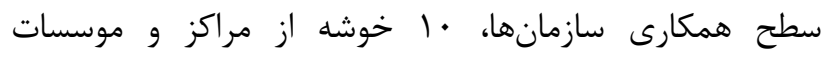

مشاركت كننده شناسايى شد (تصوير • (1).

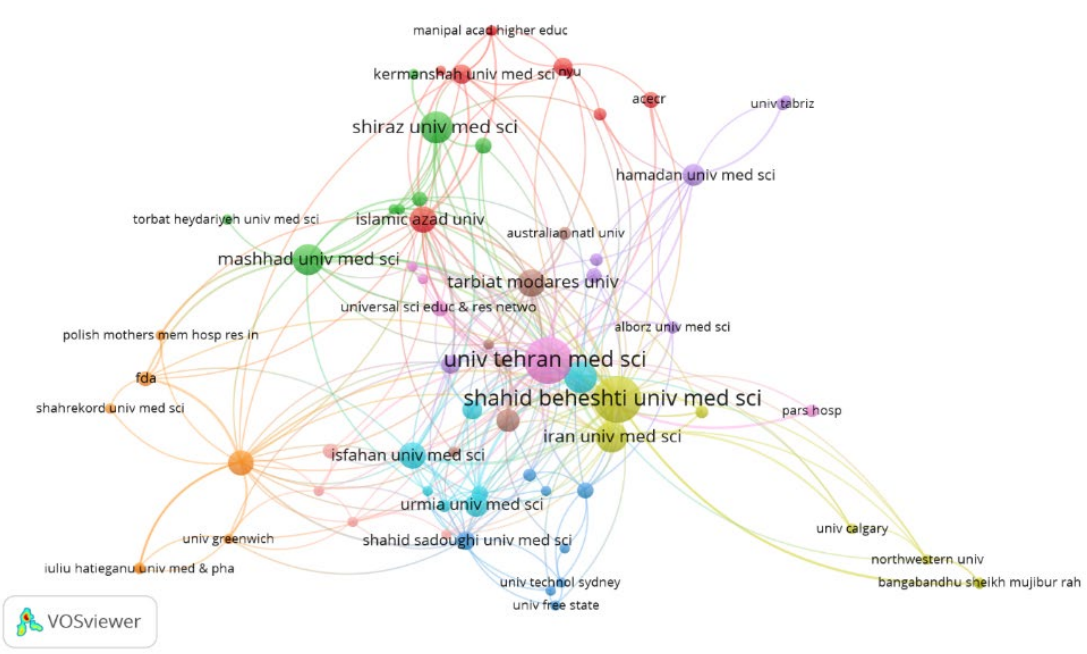

تصوير •1. نقشه همكارى علمى سازمانها در مطالعات ايران در حوزه واكسن كوويد 19 

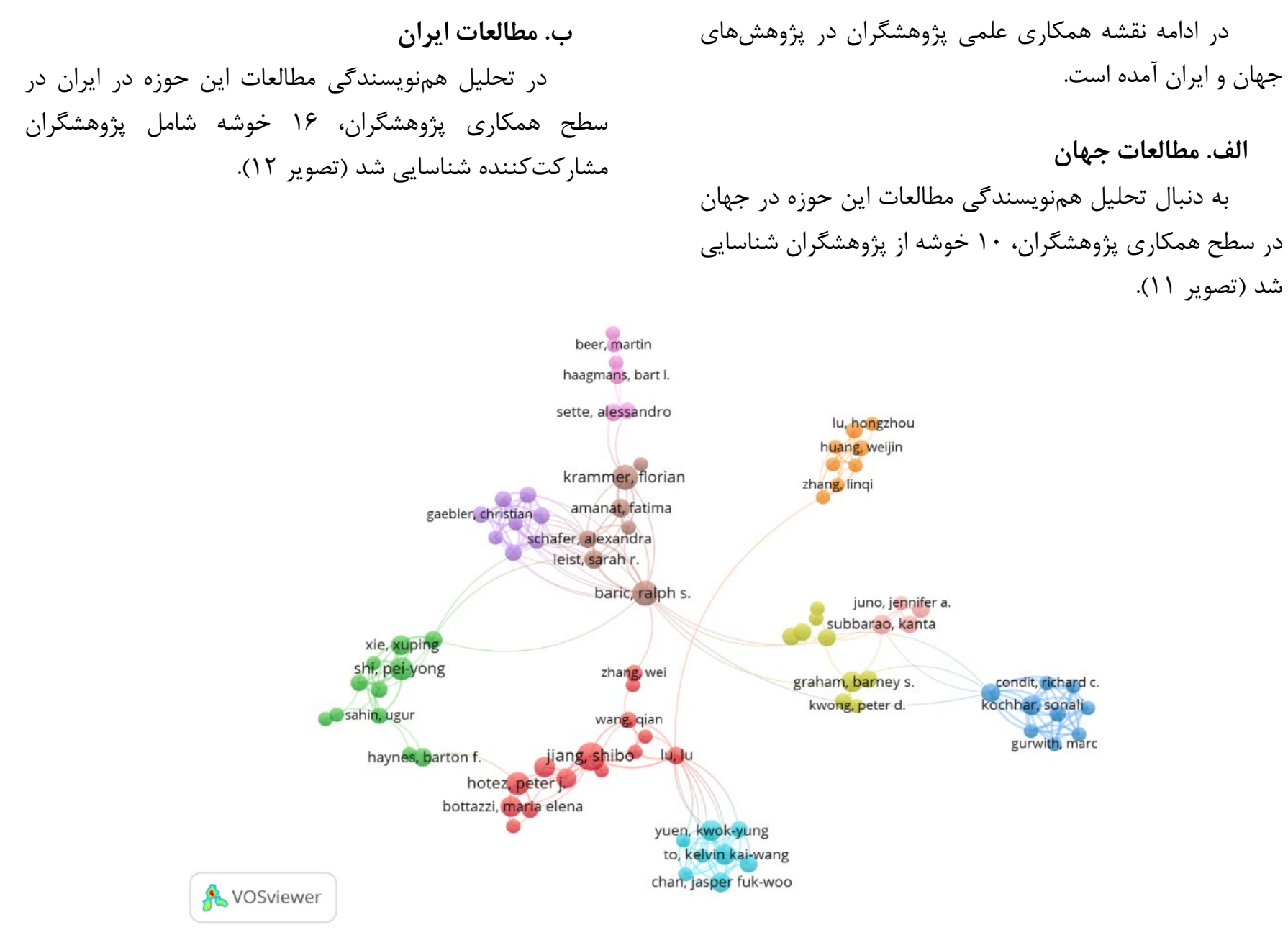

تصوير ll. نقشه همكارى علمى يزوهشكران در مطالعات جهان در حوزه واكسن كوويد 19

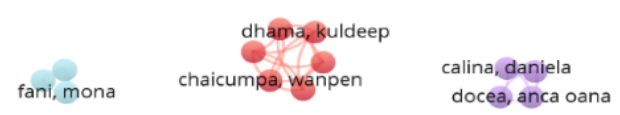

abadi, amin talebi bezmin
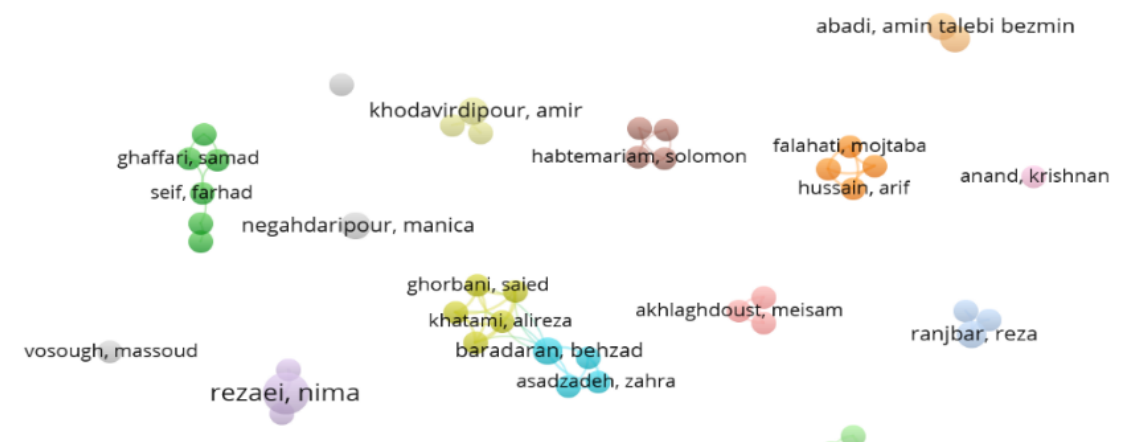

ranjbar, reza

parsamanesh, negin

bolhassani, azam

ertas, yavuz nuri

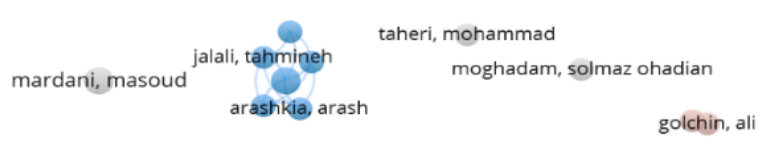

\& Vosviewer

akbari, ali

تصوير rا. نقشه همكارى علمى يثوهشكران در مطالعات ايران در حوزه واكسن كوويد 19 
يك شاخص قدرت كنترل كننده مستقيم و غيرمستقيم جريان اطلاعات در شبكه شمرده مىشوند. همجنين مقدار مركزيت

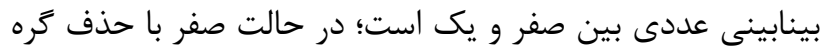

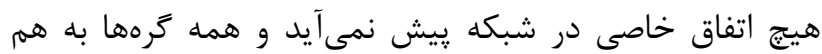

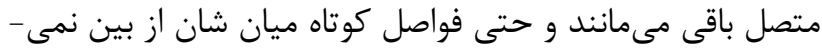

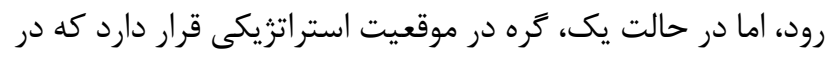
اين صورت اين گره خود مىتواند كانديداى نقطه عطف بوده و از دراز موقعيت منحصر بهفردى برخوردار باشد (YV). در ادامه ينج

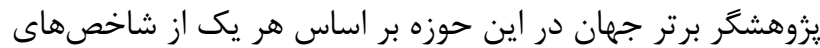
مركزيت در جدول ها آمده است.

در ادامه برخى از شاخصهاى مهم در شبكه همكارى علمى يزوزهشران جهان كزارش شده است.

در ادامه ينج يزوهشكر برتر ايرانى در اين حوزه به ترتيب شاخصهاى مركزيت آمده است (جدول V) در ادامه برخى از شاخصهاى مهم در شبكه همكارى علمى إنى يروهشكَران ايران كزارش شده است.
بر اساس ارتباطات و شبكه اجتماعى بدست آمده ميان

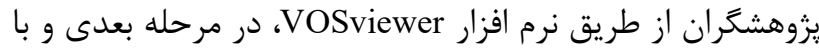

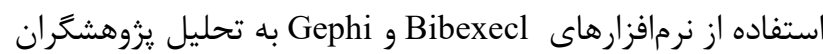
مطالعات جهان مرتبط با واكسن كوويد 19 بر اساس سنجههاى براي تران Centrality تحليل شبكههاى اجتماعى، سنجههاى Centrality فريمن شامل Betweenness, Closeness centrality ،Degree centrality centrality است. Centrality، انواع و تعداد روابطى كه عضوى از شبكه با ساير اعضاى آن شبكه برقرار كرده است را نشان مى دهد

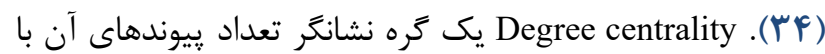

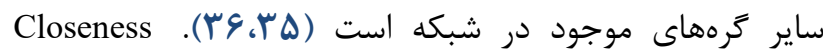

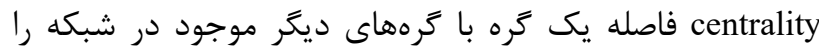

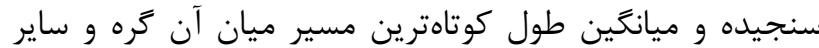
Bرهاى موجود در شبكه را نشان مى مهد (MF). Betweenness centrality

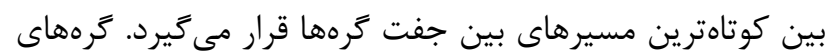

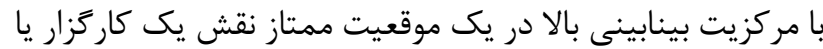

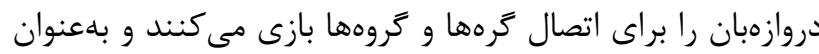

جدول ه. ينج يُروهشكَر برتر مطالعات جهان مرتبط با واكسن كوويد 19 بر اساس سنجهاى مركزيت

\begin{tabular}{|c|c|c|c|c|c|}
\hline يُزوهشكر & مركزيت درجه & بثزوهشكر & مركزيت نزديكى & بزوهشكر & مركزيت بينابينى \\
\hline Dhama K & $r$. & Iacobucci G & 1 & Liu Y & $|N| \Delta / 9 r$ \\
\hline Tiwari R & rt & Mahase E & 1 & Khan S & $\mid F V D / I T$ \\
\hline Kumar P & $r \cdot$ & Liu Y & $\cdot / r F$ & Atyeo C & ITrg/IT \\
\hline Malik YS & $r \cdot$ & Shi PY & $\cdot|r|$ & Baric RS & qVदाlf \\
\hline Patel SK & 11 & Wang L & | & Shi PY & $9 V T / T \varphi$ \\
\hline
\end{tabular}

جدول 9. شاخصهاى مئم در شبكه همكارى علمى يُروهشَران جهان

\begin{tabular}{|c|c|}
\hline f/rVF & ميانكين درجه \\
\hline$\wedge$ & ايج ايندكس \\
\hline$\cdot 1 \cdot \Delta 9$ & تراكم شبكه \\
\hline$\cdot 1 \cdot \Delta 9$ & نسبت مولفهها \\
\hline$\Delta$ & اجزا \\
\hline$\cdot \mid \Lambda \& V$ & اتصال شبكه \\
\hline - / QL & تمركز شبكه \\
\hline 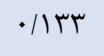 & انفكاك شبكه \\
\hline
\end{tabular}




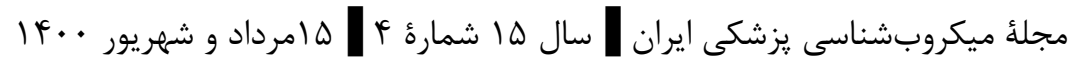

\begin{tabular}{|c|c|}
\hline F/TVF & ميانتين درجه \\
\hline $1 / 914$ & فاصله انحراف معيار \\
\hline 11 & قطر شبكه \\
\hline$r / r q \Delta$ & ميانغين طول مسير در شبكه \\
\hline$\cdot / T V K$ & فشردكى شبكه \\
\hline . /VTV & وسعت شبكه \\
\hline
\end{tabular}

جدول V. ينج يزوهشكَ برتر مطالعات ايران مرتبط با واكسن كوويد 19 بر اساس سنجهاى مركزيت

\begin{tabular}{|c|c|c|c|c|c|}
\hline بروهشكر & مركزيت درجه & يزوهشَر & مركزيت نزديكى & يزوهشكَر & مركزيت بينابينى \\
\hline منصورنيا & is & اكبرى & 1 & منصورنيا & SAT/1 \\
\hline سلطانى & $\psi_{1}$ & نبوى & 1 & برادران & rol/Ģ \\
\hline رضايى & fq & غفارى & 1 & افتخارى & $r T \cdot / 1$ \\
\hline صاحبكار & is & هدايتى & 1 & نصرتى & ra. \\
\hline جلالى نيا & fr & شريفى & 1 & رضايى & $r .911$ \\
\hline
\end{tabular}

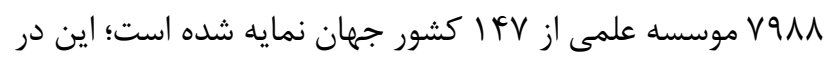

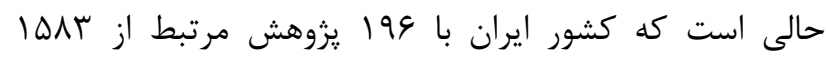

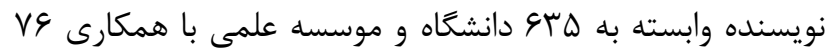
كشور در ميان كشورهاى مشاركت كننده جايگاه دهم را به خود

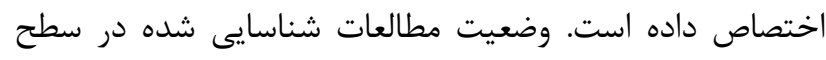

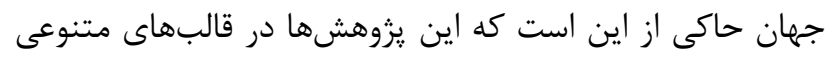

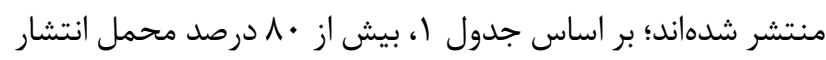

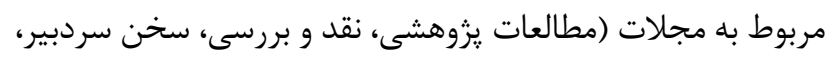

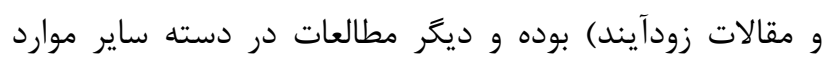

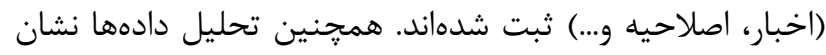

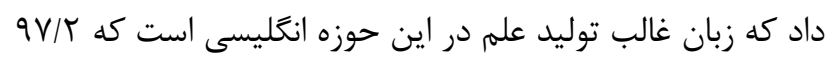

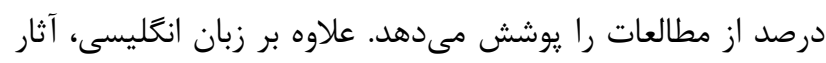

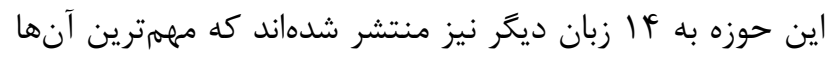

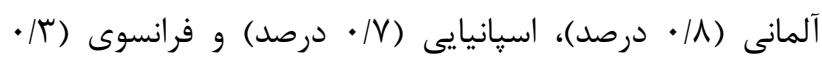

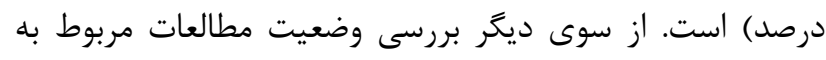

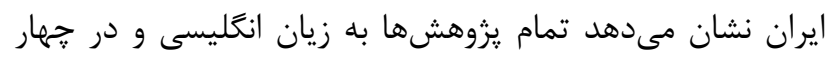

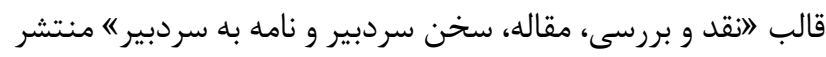

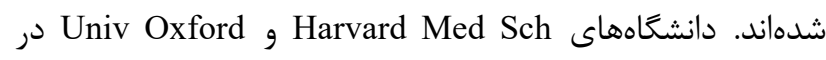

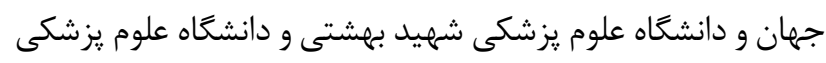

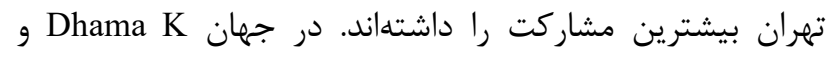
Mahase E
جدول 1. شاخصهاى ميهم در شبكه همكارى علمى يُروهشَران ايران

\begin{tabular}{|c|c|}
\hline S/Y\&A & ميانتَين درجه \\
\hline r. & إج ايندكس \\
\hline .1 .90 & تراكم شبكه \\
\hline$\cdot|r \Lambda|$ & نسبت مولفهها \\
\hline$r \Lambda$ & اجزا اجزا \\
\hline - ITtK & اتصال شبكه \\
\hline$\cdot 11 \wedge 9$ & تمركز شبكه \\
\hline - NVY & انفكاك شبكه \\
\hline $1 / F \Delta F$ & فاصله انحراف معيار \\
\hline$\wedge$ & قطر شبكه \\
\hline$r / \Delta \Delta \Delta$ & ميانَين طول مسير در شبكه \\
\hline - MTY & فشردكى شبكه \\
\hline - /ITt & وسعت شبكه \\
\hline
\end{tabular}

بحث

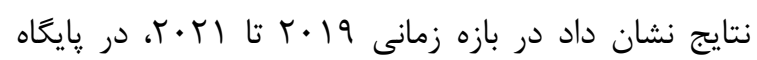

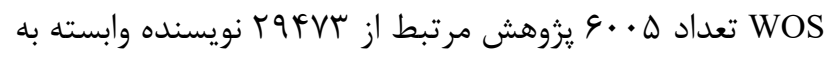


از سوى ديخر خوشه ايمونوترايى، خوشهاى نوظهور و يا قابلزوال

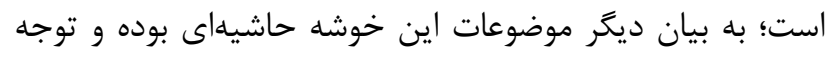

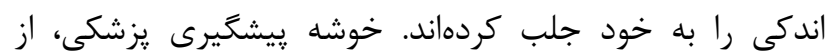
خوشههاى محورى است اما هنوز توسعه نيافته است؛ به عبارت ديكر اين خوشه هنوز به بلوغ نرسيده است.

همكارى هاى علمى در سطح كشور در مطالعات جهان و ايران

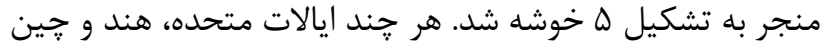
بيشترين مطالعات را داشتهاند اما بر اساس تصوير با، بيشترين مربوط به كشورهاى انغليس و سيس ايالات متحده است. Links همجنين از آنجايى كه كشورهاى شاخص در خوشهاى ساى سبز و آبى آنى

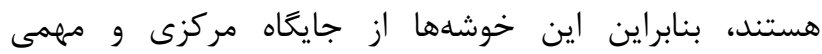

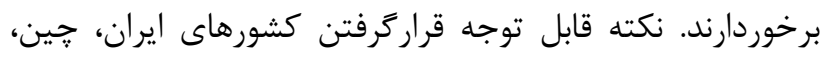
كانادا و عربستان سعودى در يك خوشه است. از سوى ديخر كشور ايران با VY كشور در اين زمينه همكارىهاى مشترك داشته است.

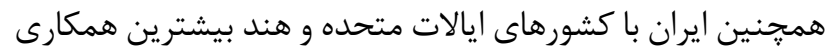

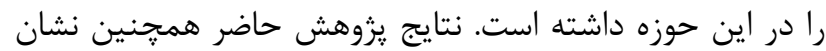

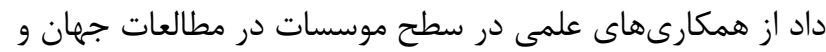
ايران به ترتيب VIV و •ا خوشه تشكيل شده است. همانطور كه دهات

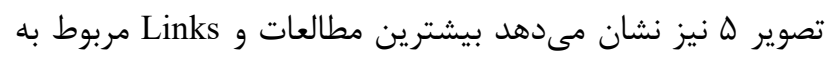
univ oxford آنكه موسسات فعال در سه خوشه نارنجى، سبز و صورتى قرار دارند

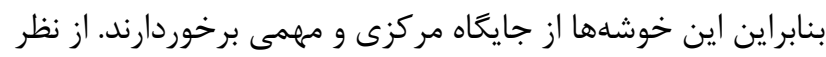

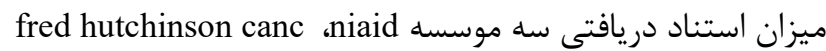
inst Pasteur ور سه جايكاه نخست قرار دارند. در حوزه مراسه مطالعات ايران، هر קند دانشخاههاى علوم يزشكى تهران و شهيد

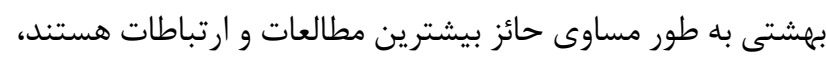

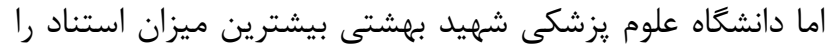

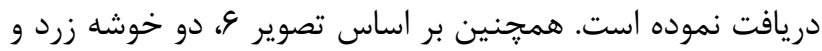

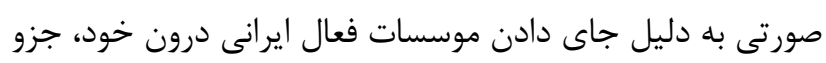

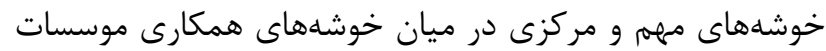
محسوب مىشوند. همجنين از همكارىهاى علمى در سطح

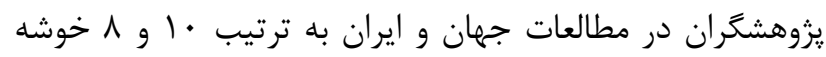

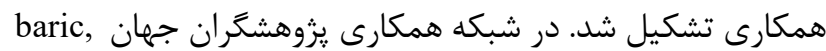

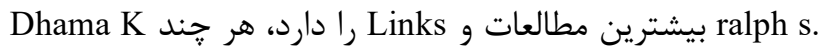

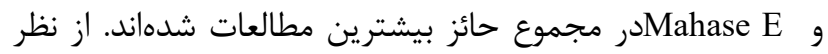

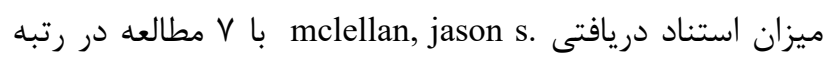
نخست قرار دارد. از سوى ديخر مىتوان از دو خوشه قهوماى و قرمز به دليل جاى دادن يزوهشكران برتر در درون خود، به عنوان آران
بيشترين مطالعات را داشتهاند. در ميان هال 1 حوزه يزوهشى

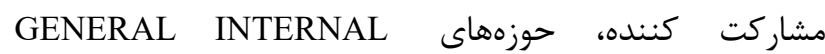
IMMUNOLOGY و در يزوهشهاى جهان و و PHARMACOLOGY PHARMACY BIOCHEMISTRY يزوهشى مشاركت مننده، حوزهان MOLECULAR BIOLOGY سمهم را در مطالعات داشته است. UNATED STATES ،DEPARTMENT OF HEALTH HUMAN SERVICES برترين حامى مالى يزوهشى در اين حوزه در سطح جهان و دانشخاه علوم يزشكى تهران، برترين حامى مالى يزوهشى در اير ايران است. خوشهبندى هموازكانى در مطالعات جهان و ايران در حوزه

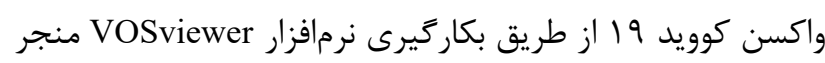
به تشكيل V خوشه شد. در ميان هفت خوشه شناسايى شده در مطالعات جهانى واكسن كوويد 9 1، جهار خوشه (زرد، سبز، قرمز و

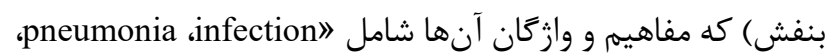
،transmission sprotein ،Sars ،spike protein spandemic «ace2 ،convalescent plasma ،chloroquine بيشتر كليدوازههاى يرتكرار و رايج در اين خوشهها هستند، بنابراين

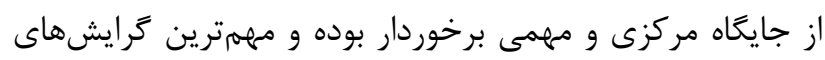
يروهشًَران اين حوزه در سطح جهان هستند؛ در ميان هفت خوشه

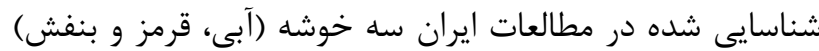

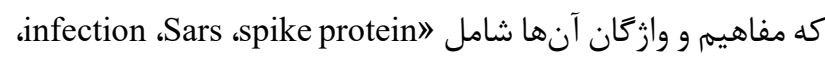
،convalescent plasma treatment pandemic spneumonia 《cytokine storm ،ace2

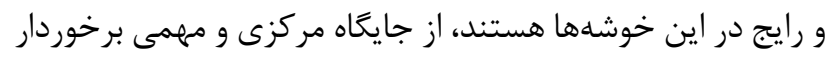
بوده و مهمترين كرايشهاى يزوهشكَران ايرانى هستند؛

خوشهبندى سلسله مراتبى در يزوهشهاى جهانى منجر به

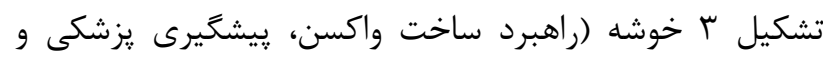

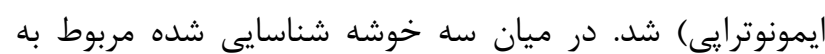
يزوهشهاى جهان، خوشههاى "راهبرد ساخت واكسن" و و "ييشخيرى يزشكى" خوشههاى توسعه يافته هستند. از سوى ديخر

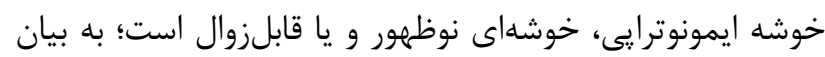
ديكر موضوعات اين خوشه حاشيهاى بوده و توجه اندكى را به خود باليه جلب كردهاند. از سوى ديخر خوشهبندى سلسله مراتبى در يزوهشهاى ايران منجر به تشكيل ع خوشه (ايمونوترايى، خرخه تشخيص و درمان، ييشكيرى يزشكى و ايمونولوزى) شد. در ميان جهار خوشه شناسايى شده، خوشههاى "جرخه تشخيص و درمان" بران و "ايمونولوزى" خوشهاى محورى نبوده اما توسعه يافته هستند. 
19 در كوتاهترين زمان ممكن مىشود. به بيان ديخر تحليل

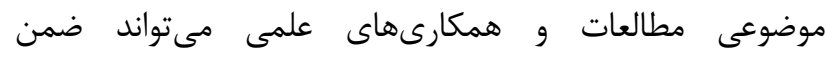
آشكارسازى موضوعات يركاربرد از يك سو و شناسايى شكافهاى

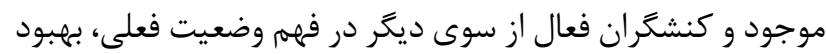

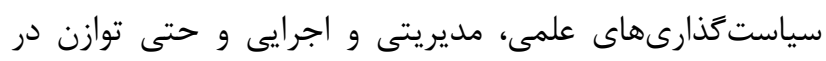
مطالعات انجام شده در حوزه واكسن كوويد 19 مفيد واقع شده و ورئي زمينه را براى شناسايى و ظهور روندها و جبهلهاى جديد يزوهشى

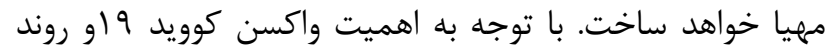

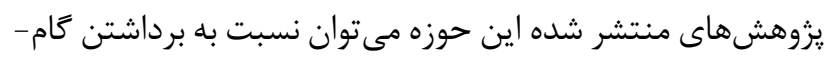
هاى عملى براى بهرهبردارى بيشتر از آن همسو با مرزهاى جناى جهانى دانش اقداماتى را از جمله شناسايى ابعاد، فرايندها، ابزارها و و

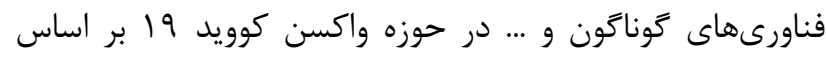
وازگًان و مفاهيم شناسايى شده و سيس انجام برنامهريزى، آماده-

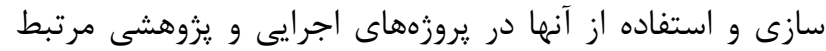

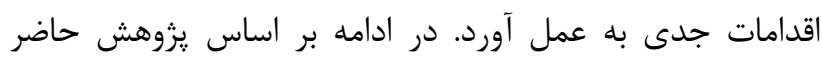
ييشنهاداتى براى انجام يزوهشهات عمل آتى آردائه مى دهود: تحليل موضوعى مطالعات اين حوزه در ديخر باياناهاى

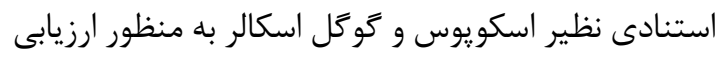
جامعترى از وضعيت يزوهش اين حوزه در جهان و ايران. تحليل محتوا و ساختار مفاهيم و وازگكان مدارك علمى

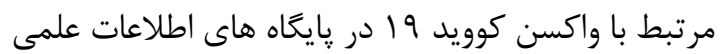
به زبان فارسى در داخل كشور و مقايسه ساختار مطالعات داخل و خارج از كشور در اين حوزه. تحليل محتوا و ساختار مفاهيم و وازَان مدارك علمى زير

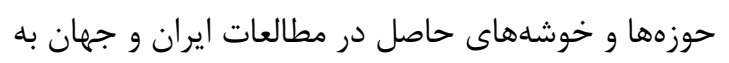
منظور شناسايى شكافهاى موجود.

$$
\text { سباسَزْارى }
$$

با تقدير و تشكر شايسته از استاد فرهيخته، جناب آقاى دكتر عليرضا نوروزى كه با يادآورى نكات ارزشمند، راهنما و راهَشاى إنى نغارند

$$
\text { تعارض در منافع }
$$

نويسندًان هيج گَونه تعارضى در منافع را كزارش نكردند.

$$
\text { منابع مالى }
$$

خوشههاى مهم و مركزى در همكارى يزوهشكران جهان نام برد.

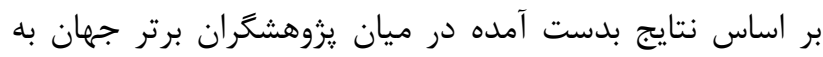

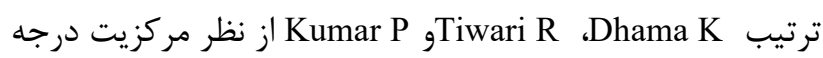
داراى رتبههاى برتر هستند. از نظر مركزيت نزديكى Iacobucci G

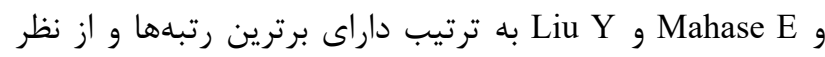

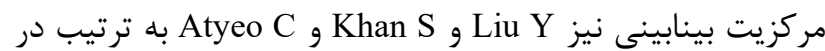
جايگًاه اول تا سوم قرار گرفتهاند. از سوى ديكر در شبكه همكارى يزوهشكران ايران نيما رضايى حائز بيشترين و استنادات دريافتى

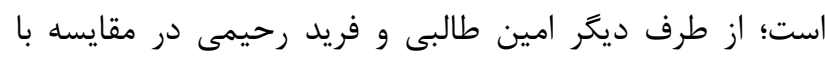
يزوهشكران ديكر ارتباطات بيشترى را برقرار نمودهاند و تشكيل

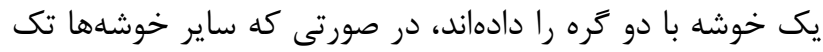

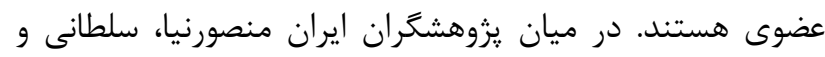
رضايى داراى بيشترين مركزيت درجه، اكبرى، نبوى و غفارى حائز بيشترين مركزيت نزديكى و منصورنيا، برادران و افتخارى داراى بيشترين مركزيت بينابينى هستند. از نظر كشورهاى شاخص در توليد و انتشار مطالعات، نتايج يزوهش حاضر با يافتههاى يزوهش Surulinathi و همكاران (YV) و Ahmad و همكاران ( (ץ) همراستا است. همجنين يافته هاى

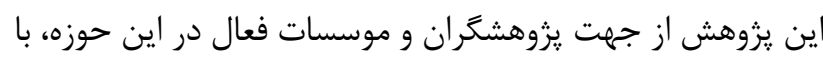

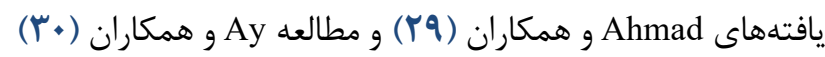

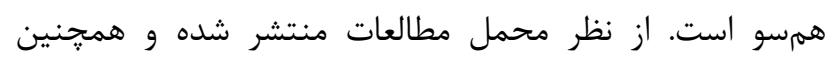

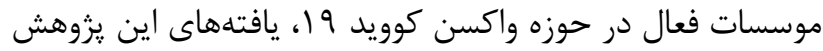
در راستاى يزوهش Ahmad و همكاران (Y ( است. ايمونولوزى، يزشكى عمومى داخلى و تحقيقات يزشكى تجربى بيشترين سهمه

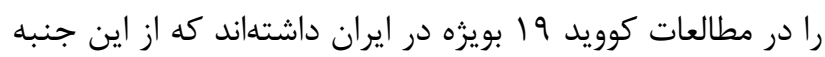

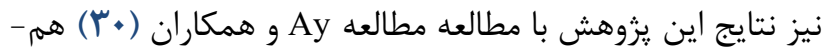

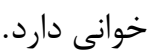
نتيجهذ نيرى با توجه شيوع كسترده كوويد 19 و افزايش تلفات انسانى آن

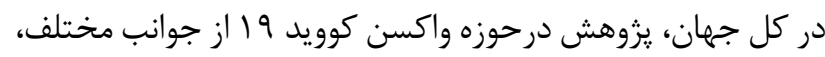

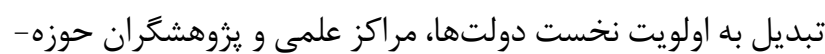
هاى علمى مرتبط در تمام جهان شده است. تحليل و مقايسه

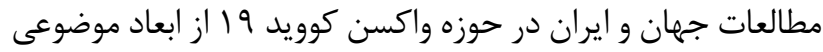

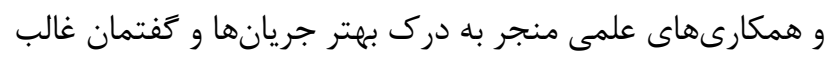
با هدف افزايش كمى و كيفى مطالعات و به دنبال آن كنترل كوويد 


\section{Referance}

1. Gralinski EL 'Menachery VD. Return of the Coronavirus: 2019-nCoV. Viruses, 2020; 12(2): 135. [DOI:10.3390/v12020135]

2. Zhao S, Musa SS, Lin Q, Ran J, Yang G \& et al. Estimating the Unreported Number of Novel Coronavirus (2019-nCoV) Cases in China in the First Half of January 2020: A Data-Driven Modelling Analysis of the Early Outbreak. J. Clin. Med, 2020; 9(2): 388. [DOI:10.3390/jem9020388]

3. Wang M, Cao R, Zhang L \& et al. Remdesivir and chloroquine effectively inhibit the recently emerged novel coronavirus (2019-nCoV) in vitro. Cell Res, 2020. [DOI:10.1038/s41422-020-0282-0]

4. Danesh F, GhaviDel S. Coronavirus: Scientometrics of 50 Years of global scientific productions. Iran J Med Microbiol. 2020 Mar 10; 14(1):1-6. [DOI:10.30699/ijmm.14.1.1]

5. Jabbari, L, Jafari, S. Analysis of research perspective, knowledge map and co-authorship patterns of Covid studies 19. Science Promotion. 1399; 11 (1): 123-144

6. World Health Organization. Surveillance case definitions for human infection with novel coronavirus ( $\mathrm{nCoV})$, interim guidance, 15 January 2020. World Health Organization; 2020.

7. Hotez PJ, Bottazzi ME, Strych U. New vaccines for the world's poorest people. Annu Rev Med. 2016; 67:405-17. doi:10.1146/ annurev-med-051214024241. [DOI:10.1146/annurev-med-051214$024241]$

8. World Health Organization. Coronavirus disease 2019 (COVID-19) situation report-71. 2020. Available

from: https://www.who.int/docs/defaultsource/Coronavirus e/situationreports/ 20200331-sitrep-71- COVID 19.pdf?sfvrsn $=4360 \mathrm{e} 92 \mathrm{~b} 8$.

9. Rothan HA, Byrareddy SN. The epidemiology and pathogenesis of coronavirus disease (COVID-19) outbreak. J. Autoimmun. 2020 May 1;109:102433 [DOI:10.1016/j.jaut.2020.102433]

10. Jafari S, Farshid R, Jabbari L. Thematic analysis of COVID 19 studies in five large continents. Scientometrics Res J. 2020;6(11):277-97

11. Shin MD, Shukla S, Chung YH, Beiss V, Chan SK, Ortega-Rivera OA, Wirth DM, Chen A, Sack M, Pokorski JK, Steinmetz NF. COVID-19 vaccine development and a potential nanomaterial path forward. Nat. Nanotechnol. 2020 Aug;15(8):646-55 [DOI: 10.1038/s41565-020-0737-y]

12. Haber P, Amin M, Ng C, Weintraub E, McNeil MM. Reports of lower respiratory tract infection following dose 1 of RotaTeq and Rotarix vaccines to the vaccine adverse event reporting system (VAERS), 2008-2016. Hum Vaccin Immunother. 2018; 1-5. [DOI:10.1080/21645515.2018.1491509]

13. Poland GA, Kennedy RB, Ovsyannikova IG, Palacios R, Ho PL, Kalil J. Development of vaccines against Zika virus. Lancet Infect Dis. 2018; 18:e211-e9. [DOI:10.1016/S1473-3099(18)30063-X]

14. Chen WH, Chag SM, Poongavanam MV, Biter AB, Ewere EA, Rezende W, et al. Optimization of the production process and characterization of the yeastexpressed SARS-CoV recombinant receptor-binding domain (RBD219-N1), a SARS vaccine candidate. Pharm Sci. 2017 Aug 1; 106(8):1961-70. [DOI:10.1016/j.xphs.2017.04.037]

15. Zhang Y, Quan L, Xiao B, Du L. The 100 top-cited studies on vaccine: a bibliometric analysis. Hum. Vaccines Immunother. 2019 Dec 2;15(12):3024-31 [DOI:10.1080/21645515.2019.1614398]

16. Corum J, Grady D, Wee SL, Zimmer C. Coronavirus vaccine tracker. The NY Times. 2020 Aug 31;5

17. Amanpour, S. The Rapid Development and Early Success of Covid 19 Vaccines Have Raised Hopes for Accelerating the Cancer Treatment Mechanism. Archives of Razi Institute. 2021; 76 (1):1-6.

18. Noroozi Chakoli A. Note from the Editor-in-Chief: Corona Crisis, Virtual Research, and Virtual Scientometrics. Scientometrics Res J. 2019 Sep 23;5(10):1-2.

19. Makkizadeh F \& Sa'adat F. Bibliometric and thematic analysis of articles in the field of infertility (20112015). International journal of reproductive biomedicine (Yazd, Iran) 2017; 15(11): 719-728. [DOI:10.29252/ijrm.15.11.719]

20. Yazdani K, Rahimi-Movaghar A, Nedjat S, Ghalichi L, Khalili M. A 5-year scientometric analysis of research centers affiliated to Tehran University of Medical Sciences. Med J Islam Repub Iran, 2015; 29 (1): 375-384.

21. Sohaili F, Shaban A, Khase A. Intellectual structure of knowledge in information behavior: A co-word analysis. Hum Info Interac. 2016 Mar 10;2(4):21-36

22. Khasseh AA, Soheili F. Tracing the Landscape of Research in Scientometrics and Related Metric Areas. Iran. J. Inf. Process. Manag. 2018 Jan 1; 33(3):941-66

23. Law J, Bauin S, Courtial J, Whittaker J. Policy and the mapping of scientific change: A co-word analysis of research into environmental acidification. 
scientometrics. 1988 Sep 26; 14(3-4):251-64. [DOI:10.1007/BF02020078]

24. He Q. Knowledge discovery through co-word analysis. Libr. Trends. 1999; 48 (1): 133-159.

25. Stefano D, Fuccella V, Vitale M, Zaccarin S. The use of different data sources in the analysis of coauthorship networks and scientific performance. Soc Networks. 2013; 35(3): 370-381. [DOI:10.1016/j.socnet.2013.04.004]

26. Galyani-Moghaddam G, Mobalegh M. CoAuthorship and Scientific Publications: A Case Study at Shahed University. The Serials Librarian. 2012; 63(3-4): 370-379.

[DOI:10.1080/0361526X.2012.700783]

27. Surulinathi M, Arputha Sahava Rani N, Srinivasaragavan S, Jayasuriya T. Research output on Covid-19/Coronavirus Vaccine: A Scientometric Study. Libr. Philos. Pract .2020; https://digitalcommons.unl.edu/libphilprac/4781/

28. Surulinathi, M, Arputha Sahava Rani N, Prasanna Kumari N, Jayasuriya T. Highly Cited Works on Covid-19 Vaccine: A Scientometric Mapping of Publications. Libr. Philos. Pract. 2021;

29. Ahmad T, Murad M A, Baig, M, Hui J. Research trends in COVID-19 vaccine: a bibliometric analysis. Hum. Vaccines Immunother. 2021; 1-6. [DOI: 10.1080/21645515.2021.1886806]

30. Ay M O, Erenler A K, Ay O O, Kaya H, Yuksel, M., \& Kekec, Z. A scientometric analysis of COVID-19 vaccine publications. WJARR. 2021; 9(3): 138-147. [DOI:10.30574/wjarr.2021.9.3.0093]

31. Jafari S, Farshid R, Mostafavi E. Co-authoring Patterns and Subject Trends in Iranian and World
Scientific Research in the Field of Information and Knowledge Organization (2001-2020). Knowledge Studies. 2020 Apr 20; 6(22):25-54.

32. Soheili F, Khasseh A A, Koranian P. Mapping Intellectual Structure of Knowledge and Information Science in Iran based on Co-word Analysis. .... 2019; 34 (4) :1905-1938

33. Danesh F, Nemat Allahi Z. Clustering the concepts and emerging events of knowledge organization. Library and information. 2021 [cited 2021May21]; 23 (2): 53-85.

34. Cuellar M J, Vidgen, R, Takeda H, Truex, D. Ideational influence, connectedness, and venue representation: Making an assessment of scholarly capital. J. Assoc. Inf. Syst. 2016; 17(1), 1-28. [DOI:10.17705/1jais.00419]

35. Erfanmanesh, M A, Arshadi, H. Correspondence Network of Institutions in Iranian Information Science and Knowledge Articles. Acad. Librariansh. Info. Res; 2013; 49 (1): 79-99. [Persian]

36. Abbasi A, Hossain L, Leydesdorff L. Betweenness centrality as a driver of preferential attachment in the evolution of research collaboration networks. JOI. 2012; 6(3): 403-412. [DOI:10.1016/i.joi.2012.01.002]

37. Hansen D, Shneiderman B, Smith, M A. Analyzing social media networks with NodeXL: Insights from a connected world. Morgan Kaufmann; 2010. 9780123822291

38. Delavar A. Probability and Applied Statistics in Psychology and Educational Sciences. Tehran: Roshd; 2007 